\title{
LA VILLA ROMANA DE VERANES (GIJÓN, ASTURIAS). APORTACIONES PRELIMINARES SOBRE LA TRANSFORMACIÓN FUNCIONAL DEL ASENTAMIENTO EN LA TARDÍA ANTIGÜEDAD
}

\author{
Carmen Fernández Ochoa, Fernando Gil Sendino, Almudena Villar Calvo; Natalia Fernández Rodríguez; Gonzalo Álvarez \\ Toledo y Orlando Morán Fernández
}

Universidad Autónoma de Madrid

\begin{abstract}
Resumen
A partir de las excavaciones realizadas en un amplio sector del patio norte de la villa romana de Veranes, se analiza la evolución cronoestratigráfica del asentamiento en los últimos momentos de su función como villa. Asimismo, se presenta una información preliminar sobre la transformación del yacimiento durante el periodo tardoantiguo.
\end{abstract}

Palabras clave: Villa romana, Gijón (Asturias), transformación de villas tardorromanas.

\begin{abstract}
Based on the results of excavations carried out in a wide sector of the North Courtyard of the Roman Villa of Veranes, we have analysed the chrono-stratigraphic evolution of this settlement during its latest period functioning as a villa. In addition, we provide some preliminary information relating to the changes suffered by the archaeological site during the late Antiquity.
\end{abstract}

Key words: Roman villa, Gijón (Asturias), changes of later roman villas.

\section{Introducción $^{1}$}

Nadie pone en duda, hoy en día, que la aproximación al conocimiento histórico sobre el poblamiento rural antiguo conlleva planteamientos íntimamente relacionados con los particularismos regionales, o dicho de otro modo, con la necesidad de estudios microrregionales específicos de amplio espectro. Este hecho no supone negar la existencia de un trasfondo

\footnotetext{
${ }^{1}$ Este trabajo se ha realizado en el marco del Proyecto "La villa de Veranes (Gijón, Asturias). Potencialidad productiva y evolución de su dominio" sufragado por la FICYT del Principado de Asturias ( PC04-29SPV) en colaboración con el Ilmo. Ayuntamiento de Gijón cuya investigadora principal es C. Fernández Ochoa
}

común para cada momento histórico, pero la materialización de esos rasgos generales encuentra una explicación más coherente en la observación de los condicionantes y variaciones presentes en cada contexto geo-histórico concreto.

Una segunda consideración, que quizá algunos encuentren superflua pero que sigue siendo necesaria, es la certeza de que únicamente la realización continuada de excavaciones arqueológicas rigurosas permite el acceso a una información material contrastada en la que podamos percibir los fenómenos que definen los momentos de ocupación, uso, abandono y/o reocupación de los enclaves rurales antiguos y su relación con el territorio. Únicamente contando con esta garantía se pueden 
proponer modelos explicativos sobre la evolución de un asentamiento, su configuración espacial y territorial, sus sistemas productivos y, en definitiva, sobre la mentalidad y modos de vida de las gentes que habitaron cada uno de estos lugares lo que permite analizar y explicar la evolución social del paisaje.

Por otra parte, es preciso también reflexionar sobre la ingente cantidad de datos perdidos no solo por la antigüedad de algunas intervenciones sino también, y esto es lo más grave, por la sistemática destrucción del patrimonio que no cesa a pesar de las prevenciones y condenas que impone la legislación vigente. Si además centramos nuestra atención en el estudio concreto del desarrollo histórico de las villae en la península ibérica, las dificultades se acrecientan por las restricciones y "olvidos" que aún se detectan en algunas actuaciones arqueológicas. Nos referimos, obviamente, y en primer lugar, a las excavaciones centradas exclusivamente en la parte señorial de la villa o si se prefiere, las que buscan prioritariamente la obtención de restos de mármoles o de mosaicos ${ }^{2}$. En segundo término y en la misma línea, hay que citar las intervenciones que pasan por alto los indicios de ocupación post-romana y, finalmente, la carencia de un tratamiento específico del papel de la villa como explotación agropecuaria utilizando una metodología arqueológica precisa (Fernández Ochoa, Gil Sendino, y Orejas, 2005) más allá de las meras alusiones, no exentas de subjetivismo, a las evidentes posibilidades que ofrecen los terrenos donde se implanta una villa.

Por fortuna, en las dos últimas décadas se ha generado, dentro y fuera de la península ibérica, una documentación arqueológica sobre el mundo rural romano cada vez más nutrida, amparada en metodologías de excavación y prospección fructíferas Fernández Ochoa y Morillo, 2005). Los resultados obtenidos permiten replantear viejos problemas de definición sobre la dinámica histórica de las villae y, a la vez, esbozar nuevos enfoques sobre un fenómeno cuyo estudio, muy limitado en las fuentes escritas, siempre ha estado sometido a numerosas dificultades interpretativas (Brogiolo, (ed.) 1996; Chavarría, 2004).

\section{Presentación de los datos: la excavación del área de la puerta}

Desde el año 1997 y dentro de lo que hemos denominado como "Segunda Etapa del Proyecto

2 Villas significativamente bautizadas por la Dra. Fernández- Posse como "villas alfombra".
Gijón de Excavaciones Arqueológicas" (Fernández Ochoa, 2003) se realizan excavaciones sistemáticas en la villa romana de Veranes (Fig. 1). Este asentamiento dista unos $8 \mathrm{~km}$ de la ciudad de Gijón y se halla situado al sureste del concejo junto al ramal transmontano de la vía que arranca de la Ruta de la Plata procedente de Astorga y León. (Fernández Ochoa, et alli 2004 y 2005) (Fig. 2).

Las fuentes de información general sobre el yacimiento y las primeras actuaciones llevadas a cabo han sido dadas a conocer en varios trabajos a los que remitimos (Fernández Ochoa et alli 1998, Fernández Ochoa y Gil Sendino 1999, Gil Sendino 2002, Fernández Ochoa 2003, Fernández Ochoa, Gil Sendino y Orejas, 2005). Nuestro objetivo en el presente estudio es presentar un avance sobre la evolución cronoestratigráfica del asentamiento en los últimos momentos de su función como villa y plantear algunas cuestiones sobre las transformaciones del enclave durante el periodo tardoantiguo.

Para llevar a cabo esta aportación, hemos seleccionado una zona del yacimiento correspondiente a la puerta de acceso del patio norte y su entorno inmediato que conforma un área de unos $100 \mathrm{~m} 2$ definido por los cuadros 494/540, 494/536, $500 / 540$ y 500/536 que fueron excavados en área (Fig. 3) ${ }^{3}$.

\section{Dinámica cronoestratigráfica}

La secuencia estratigráfica, relativamente sencilla, la forman la cubierta vegetal (UE 1001), de escasa potencia, asentada sobre un nivel de sedimentación de la ladera (UE 1002) compuesta por una arcilla compacta de color anaranjado con intrusiones de bloques calizos de pequeño tamaño y esquirlas calizas desplazadas por la pendiente. Se encuentra muy alterada por las labores agrícolas de época moderna. Los materiales asociados son escasos, heterogéneos y muy rodados. Bajo estas unidades se localiza un depósito de origen medieval (UE 4050) formado por un sedimento arcilloso y negruzco de textura muy compacta, sin apenas inclusiones de piedras calizas. Contiene abundantes manchas de carbones y pequeños guijarros. Su composición es muy homogénea. Los materiales aparecen en posición secundaria arrastrados por la pendiente ${ }^{4} \mathrm{y}$,

3 Sobre la metodología concreta empleada en la excavación remitimos a nuestra publicación de 1998 (Fernández Ochoa et alii, 1998)

${ }^{4}$ La zona de estudio se sitúa en el extremo occidental del espacio utilizado en época medieval $\mathrm{y}$ 
aunque dominan los adscritos a la Edad Media, también se recuperan otros romanos procedentes de las alteraciones del los estratos inferiores durante el uso de la zona como necrópolis medieval. Este nivel conserva indicios efímeros de ocupación como son los restos de un hogar y un pequeño agujero de poste. La unidad cubre la cabecera de los muros de la estancia E-20 y las unidades estratigráficas 4051 y 4169.

La Unidad Estratigráfica 4051 se ha identificado como un estrato formado por los procesos de amortización y nivelación de este espacio con escombros de bloques calizos de mediano y gran tamaño, por lo general canteados y procedentes de los muros, junto a numeroso material latericio bastante rodado y varios fragmentos de sillares de arenisca. Los restos constructivos aparecen mezclados con un sedimento arcilloso y compacto, de color negruzco y con abundantes carbones.

Al oeste de esta unidad (UE 4051), se ha individualizado un estrato (UE 4169) de características similares que interpretamos como la remoción del derrumbe (UE 4170) de uno de los muros del edificio romano.

Bajo este depósito (UE 4051) se documentan las evidencias del proceso de saqueo de la villa tras su abandono (UE 4165). Esta unidad contiene los residuos de la cubierta del edificio que no son aprovechados. Se trata de una acumulación intencionada de restos de tégulas e ímbrices, por lo general bastante fragmentados. Entre los fragmentos se encuentra una tierra arcillosa muy compacta formada por una mezcla de arcillas, una negruzca y otra anaranjada. Apenas existen inclusiones de piedras, limitándose a algún pequeño bloque calizo, y dos sillares de arenisca. El material asociado es muy abundante. Este depósito sella el pavimento exterior romano en la zona norte del patio (UEM 4402), que se distribuye parcheando los huecos entre los afloramientos rocosos del sustrato geológico (UE 4488). Dicho pavimento se compone de pequeños guijarros de cuarcita, esquirlas de piedra caliza y, en menor medida, esquirlas de material latericio. Su trabazón es de arcilla compacta y negruzca. No se trata de un pavimento homogéneo, sino que su uso parece haber sido continuo y con abundantes reparaciones.

Como ya hemos dicho, al sur de la zona estudiada registramos el derrumbe (UE 4170) de los muros Y88 e Y-54 formado por sillares calizos de tamaño medio y grande, junto con alguna arenisca $\mathrm{y}$

topográficamente se corresponde con una ligera pendiente que favoreció la sedimentación del estrato. pequeños fragmentos de material latericio rodado. El sedimento es arcilloso, de una tonalidad ocre y una textura algo arenosa por las intrusiones de argamasa. Los bloques calizos se encuentran trabados entre sí formando un talud sur-norte en el que los sillares superiores se apoyan en los inferiores. Los materiales asociados son escasos.

Sellada por los derrumbes se localizó, junto al paramento Y 54 una acumulación de tégulas e ímbrices (UE 4166) procedentes de los aleros de la cubierta del edificio y desprendidas en el proceso de desmantelamiento de los tejados de la zona occidental de la villa. La tierra que conforma esta unidad presenta una textura poco compacta, las tejas se retiran con facilidad y entre ellas existe un sedimento oscuro y arcilloso con paquetes de arcilla anaranjada y contaminaciones de carbones y argamasa. Sobre este depósito existe una fina capa cenicienta de carbones donde se concentra abundante material arqueológico, sellado por el derrumbe (UE 4170). Este nivel indica un lapso temporal entre el desmantelamiento del tejado y el posterior derrumbe y amortización de los muros de esta zona de la villa. El material asociado es muy abundante, destacando los numerosos clavos y ganchos procedentes de las cubiertas.

Bajo el nivel de latericio (UE 4166) se encuentra un depósito arcilloso muy compacto y negruzco, con abundantes esquirlas calizas, bolsas de argamasa y carbones (UE 4401). Los materiales asociados son muy abundantes. Este estrato se formó durante el último momento de uso y abandono de las edificaciones en el sector occidental de la villa.

A partir de la secuencia estratigráfica establecida podemos efectuar una propuesta de reconstrucción de la dinámica histórica en esta zona del yacimiento tal como se expresa en el diagrama estratigráfico del área estudiada (Fig.4).

\section{FASE I}

La ocupación más antigua detectada en el espacio analizado se corresponde con los depósitos formados durante el uso y primeros momentos de abandono de la puerta de acceso a la pars urbana y al patio norte de la villa. Esta fase aparece representada por la UE 4401, sedimento que contiene exclusivamente escasos materiales arqueológicos adscribibles a la segunda mitad del siglo IV y al siglo $\mathrm{V}$, como algunos fragmentos de TSHT de círculos secantes y algún fragmento de imitación de TSGGT. 


\section{FASE II}

Una segunda fase viene determinada por la apreciación de diferentes procesos de expolio y desmantelamiento de las estructuras (Fig. 5). La documentación arqueológica permite interpretar este proceso como algo inmediato al fin del uso de este sector como espacio habitado y ha quedado constatado en unidades estratigráficas formadas durante el saqueo del tejado (UE 4166) o en el transcurso del desmonte de los paramentos (UE 4170). Tras su abandono, las edificaciones fueron rápidamente expoliadas; las puertas y ventanas fueron desmontadas, las tejas robadas y los sillares de arenisca arrancados de los muros para ser utilizados en edificaciones próximas. En el intervalo de tiempo que dura este proceso hemos registrado también restos de latericio (UE 4165) desechado en las acciones de amortización de los elementos constructivos y las alteraciones de los derrumbes de los paramentos durante los procesos de amortización de las ruinas (UE 4169).

\section{FASE III}

Un tercer periodo, adscrito a la época medieval, queda definido a partir de dos procesos arqueológicos diferenciados. La Fase IIIa corresponde a un espacio temporal difícil de aquilatar pero que hubo de ser necesariamente prolongado; se fueron formado nuevos depósitos (UE 4051) fruto de las rebuscas entre los escombros de las ruinas y de los rellenos destinados a crear una nueva superficie horizontal. Las unidades de esta fase, además de abundantes restos constructivos, contienen materiales arqueológicos de cronología tardorromana y algunos fragmentos cerámicos ya claramente medievales. La Fase IIIb queda conformada por la UE 4050, nivel de sedimentación con abundante material arqueológico y en el que se han podido documentar evidencias de zonas de hábitat. Es en esta unidad donde se ha individualizado el negativo de un poste de madera y los restos de una estructura de combustión formada por una torta de arcilla rubefactada perteneciente a un fuego de hogar puntual o de uso relativamente corto (Fig. 6). Los materiales arqueológicos asociados a este estrato reflejan una ocupación alto y pleno medieval.

\section{El patrón material del último periodo de la villa tardorromana}

El conjunto material exhumado en el área excavada refleja con claridad el último momento de uso de la villa en plenitud de funciones y su posterior y rápida amortización. En el inventario incluido al final de este texto, se ofrece la relación de materiales por unidades estratigráficas, atendiendo a un orden de antigüedad y tipo de material: cerámicas, vidrios, metales, monedas etc.. Cada pieza lleva la referencia concreta al contexto de su aparición y el número de inventario junto con la indicación de la figura donde se ha plasmado su dibujo ${ }^{5}$. Las pastas y los barnices de la terra sigillata se han clasificado según el Code des couleurs des sols de A. Cailleux. Las cerámicas comunes se han descrito atendiendo a criterios funcionales y tecnológicos.

\section{Cerámica de época romana}

Los materiales cerámicos asociados al área excavada revelan que la cerámica común romana es la mejor representada en el conjunto con un $67 \%$ del total; a esta producción le sigue la TSHT con un 29\%, mientras que la TSH y la TSGGT están registradas solamente con un $2 \%$. La presencia de cerámica de Paredes Finas, ánforas e imitaciones de TSGGT es meramente anecdótica (cuadro 1).

\section{PORCENTAJES CERÁMICOS.} NIVELES DE ABANDONO
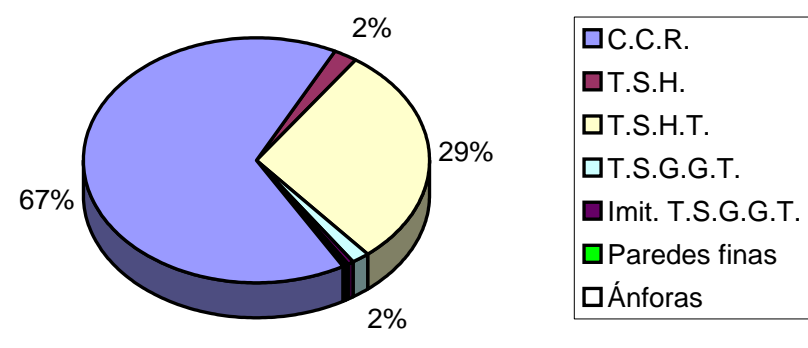

\section{CUADRO 1}

\section{La terra sigillata hispánica}

Las producciones de terra sigillata presentan un alto grado de fragmentación, aspecto que ha dificultado en muchas ocasiones su adscripción morfológica. Las producciones altoimperiales suponen un $2 \%$ del conjunto cerámico. De los once fragmentos recuperados sólo dos nos indican forma, uno proviene de la UE 4165 y pertenece a una forma $15 / 17(17 / 1)$, y el otro es un fragmento de borde que se corresponde con una forma 4 -aunque sin decoración a ruedecilla- procedente de la UE 4169 (Fig. 26/1).

La producción mejor representada dentro de este conjunto cerámico se corresponde con las series

\footnotetext{
${ }^{5}$ En contadas ocasiones se ha omitido el dibujo de alguna pieza pero se ha contabilizado en la estadística final.
} 
hispánicas de cronología tardía (TSHT) con un $29 \%$ de un total de 148 fragmentos.

Las formas lisas de TSHT están representadas por nueve fragmentos. En la UE 4165 se han recuperado dos fragmentos de la forma 74/Palol 4 (Fig. 17/4). Este tipo de platos han sido fechados en Saldaña entre el primer y segundo tercio del siglo IV (Juan Tovar, 2000: 66). En este estrato también contamos con el perfil completo de un plato carenado perteneciente a la forma 77/Palol 5/82 A Paz Peralta (Fig.18/9) y un fragmento de borde de plato de la forma 80/ Palol 1 (Fig.17/5) (Juan Tovar, 2000: 7576). El plato forma 77/Palol 5/82 A Paz Peralta tiene amplia dispersión por la Cornisa Cantábrica, el valle del Ebro y la Meseta Norte y su cronología abarca del s. III al V (Juan Tovar, 2000:71). Por otra parte, las formas 80/ Palol 1 sitúan el origen en la segunda mitad del s. IV o más probablemente en su último tercio, perdurando en la primera mitad del s. V. Otro fragmento de borde ha sido identificado con la forma 6/Palol $8 c^{6}$ (Fig. 21/1). Palol (Palol y Cortés,1977) adscribe estas producciones entre la segunda mitad del s. IV y la mitad del s.V; un ejemplar de Quintanilla de la Cueza también presenta clara cronología tardía (Juan Tovar,2000: 91-92). Además contamos con cuatro bordes de cuenco de la forma 37 sin que podamos determinar con seguridad si pertenecen a formas lisas o decoradas.

En cuanto a las formas decoradas, contamos con dos bordes y cuatro fragmentos indeterminados; un borde pertenece a la forma 6/Palol 8 b (Fig. 17/2), localizado en la UE 4165, en esta misma unidad tenemos un borde perteneciente a la forma 37 (Fig. 17/3), del tercer estilo de grandes círculos, datable a partir del segundo tercio del s. IV (Juan Tovar, 2000: 89). Las formas indeterminadas son una base decorada con bastoncillos segmentados en zig-zag (Fig. 18/10), que tiene su paralelo en un ejemplar localizado en las excavaciones de la muralla de Gijón con decoración del tipo 2 A2/12 de López Rodríguez, (1985) (Fernández Ochoa y Zarzalejos, 1997: 95); esta decoración es frecuente en las bases de la forma 77/Palol 5 a la que puede pertenecer este fragmento; también contamos con tres fragmentos de pared con motivos de cestería (Fig. 18/11), asignables al cuarto estilo, con moldes localizados en el yacimiento burgalés de Valdelahorca distribuidos mayoritariamente por la Meseta Norte y con cronología paralela a los grandes círculos (Juan Tovar, 2000: 91); otro fragmento de pared, localizado en la UE 4169 presenta círculos y rosetas (Fig. 26/5),

\footnotetext{
${ }^{6}$ Mezquiriz, (1985: 127 y 130) mantiene la forma 5 para las producciones altoimperiales y da al cuenco tardío el número 6.
}

motivos similares aparecen en la excavación de la muralla de Gijón en los estratos V y VI con cronología del segundo tercio del s. IV d.C. (Fernández Ochoa y Zarzalejos,1997: 94). El último fragmento, localizado en la UE 4401, conserva restos muy deteriorados de decoración a molde de círculos secantes (Fig. 29/1).

\section{Terra sigillata gris galica tardía e imitaciones}

La producción de terra sigillata gris gálica (TSGGT) está representada por el $2 \%$ del conjunto cerámico de los niveles de abandono; se han documentado nueve fragmentos de los que uno es una base anular de 4,6 $\mathrm{cm}$ de diámetro (UE 4165) y otro un fragmento de pared con carena (UE 4169). En Gijón, la presencia de estas producciones alóctonas es muy reducida aunque se ha localizado en las termas (Fernández Ochoa, García Díaz, y Uscatescu 1992) y en la muralla y confirma la existencia de estas importaciones en el ámbito cantábrico entre mediados del s. V y primera mitad del s. VI.

Las imitaciones de terra sigillata gálica tardía están constatadas con dos fragmentos pertenecientes a la misma pieza, decorada con estampilla en serie de rosetas (UE 4401, $\mathrm{n}^{\circ}$ de inventario 16.542). Estas producciones fueron estudiadas en 1994 por Uscatescu, Fernández Ochoa y García Díaz, quienes documentaron su amplia difusión en el Norte peninsular.

En cuanto a las paredes finas contamos con un único fragmento de borde localizado en la UE 4166(Fig. 21/3).

\section{Cerámica común romana}

El conjunto cerámico mayoritariamente representado en los estratos objeto de este análisis es el de la cerámica común romana con un $67 \%$. La dificultad en el estudio de los repertorios de la cerámica común radica en su escasa evolución tecnológica y formal inherente a su función práctica-, que siempre ha impedido afinar cronologías lo que ha provocado un reducido interés por su estudio. Sin embargo, investigaciones realizadas en los últimos años van aportando datos que arrojan luz sobre el conocimiento de estas producciones ${ }^{7}$. La cerámica

\footnotetext{
${ }^{7}$ Entre otros muchos trabajos, además de los de Gijón o Llanera que constituyen nuestra referencia básica para Asturias, podemos recordar algunas publicaciones recientes como la monografía de las cerámicas comunes de la villa de Sâo Cucufate de Vaz Pinto (2003) y, por cercanía geográfica, los estudios de
} 
común romana ${ }^{8}$ se ha clasificado de acuerdo con los grupos establecidos por C. Fernández Ochoa y M. Zarzalejos en el estudio de los materiales de la muralla de Gijón atendiendo a las características técnicas en relación con la factura, la cocción, las pastas y los tratamientos de la superficie (Fernández Ochoa y Zarzalejos, 1997: 96-104).

La muestra estudiada se caracteriza por alto índice de fragmentación. Se han documentado un total de 334 fragmentos pertenecientes a cerámica común que se han incluido en los grupos 1 a 6 y 10. El grupo con representación porcentual más amplia en el grupo 2 con un $36 \%$ y un notable predominio de las ollas (Cuadro 2).

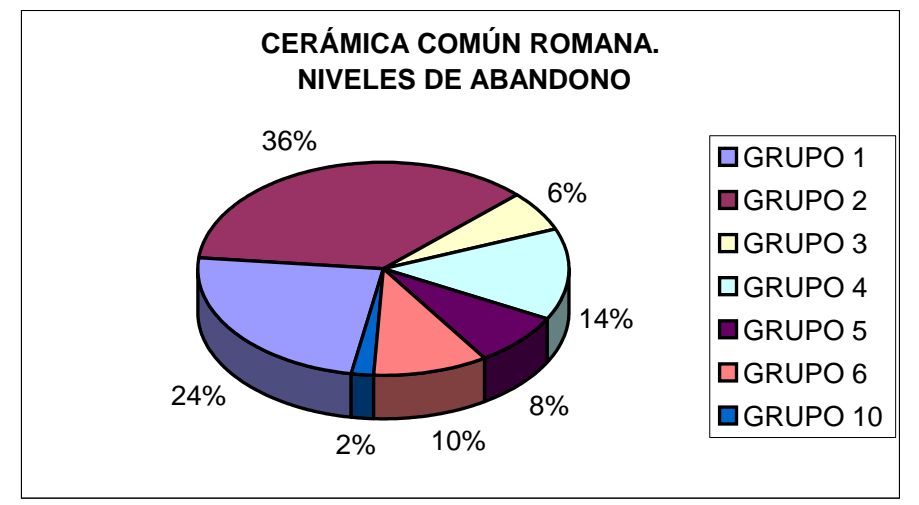

CUADRO 2

GRUPO 1. Este grupo se caracteriza por la ejecución a torno, la cocción oxidante, la presencia de pastas muy decantadas con desgrasantes finos o muy finos y las superficies alisadas cuidadosamente. Representa un $24 \%$ de la cerámica común, con 82 fragmentos contabilizados, entre los que se ha podido diferenciar un borde de olla (Fig. 8/2), un borde de cuenco (Fig. 26/6) que se correspondería con la forma III B de Vaz Pinto, y un borde de jarra de boca estrecha (Fig. 26/5); además contamos con una serie de bases planas y con un asa de cinta (Fig. 21/8).

GRUPO 2. Se define por la utilización del torno/torno lento, la cocción mixta, el empleo de barros compactos con desgrasantes finos, superficies homogéneamente arenosas con una distribución muy uniforme de las partículas. Los recipientes pueden llevar decoración incisa en borde y pared. Este grupo

Alcorta (2002) para Lugo o los de Martínez Salcedo.( 2004) para el área vasca.

8 Entendida aquí como cerámica de cocina, mesa y almacenaje doméstico, excluyendo la producción de ánforas. es el más abundante en los niveles de abandono de Veranes con un $36 \%$ del total de cerámica común. El recipiente mejor representado es la olla con borde exvasado y engrosado o bien borde horizontal de sección triangular, cuerpo ovoide y base plana. Los bordes de sección triangular con decoración incisa concéntrica están bien representados en contextos tardíos de la excavación de la muralla romana de Gijón (Fernández Ochoa y Zarzalejos, 1997) y en las excavaciones de la Plaza del Marqués (Fernández Ochoa 1994) también en Gijón y su distribución se generaliza por todo el Norte peninsular. El resto de ollas, las de borde exvasado, sería el equivalente a la forma genérica Vegas 1 (Vegas,1973: 11-14). Además contamos con una serie de bases planas y varios fragmentos de pared con decoración incisa a peine que pueden asignarse a ollas. Por último, se ha documentado un borde de jarra con pico vertedor.

GRUPO 3. Se caracteriza por la utilización del torno/torno lento, cocciones mixtas, pastas poco decantadas con desgrasantes gruesos/muy gruesos y superficies sin tratar o con alisados someros. Como en el grupo anterior, las ollas pueden llevar decoración incisa en paredes y bordes. Este grupo ocupa el 6\% del conjunto y la forma mejor representada del conjunto son las ollas con tres ejemplares, uno con el borde exvasado (Fig. 27/11) y dos de borde horizontal, uno de ellos con decoración a peine en el borde e incisión en V (Fig. 27/12) y otro con decoración incisa concéntrica en el borde e incisa vertical en la pared. A esta forma pueden corresponder varias bases planas recuperadas en la excavación. También se ha documentado un asa de jarra decorada con líneas incisas (Fig. 27/13).

GRUPO 4. Representa un $14 \%$ del total de la cerámica común. Aquí se incluyen no sólo las fuentes de imitación de rojo pompeyano tal como se hizo en la clasificación de la muralla romana de Gijón (Fernández Ochoa y Zarzalejos, 1997: 101-102) sino además todas las cerámicas de pastas micáceas con engobe rojo incluyendo así platos con diámetros pequeños y varios cuencos. Estas producciones parece que perviven en épocas tardías como atestiguan las excavaciones de la muralla y de la fábrica de salazones de Gijón, donde su presencia es constante en los estratos del s. IV y quizá primera mitad del s. V. d.C. (Fernández Ochoa y Zarzalejos, 1997: 101-102; 1994: 55).

GRUPO 5. Se trata de piezas realizadas a torno cocidas en ambientes reductores con pastas duras y desgrasantes finos o muy finos. En los acabados dominan los alisados cuidados. Esta producción se asocia a niveles de construcción de la muralla de Gijón y continúa a lo largo del s. IV (Fernández 
Ochoa y Zarzalejos, 1997: 102). En estos niveles de abandono de la villa de Veranes representan un $8 \%$ del total de cerámica común. Se han documentado varios fragmentos del borde, la base y el asa de una jarrita, (Fig. 19/22, 23 y 24) y un posible pie de copa (Fig. 19/25).

GRUPO 6. Este grupo incluiría tanto piezas modeladas a torno como a torno lento, cocidas tanto en ambientes reductores como oxidantes y pastas poco decantadas con alto contenido en micas. Este grupo aparece representado con un $10 \%$ del total de la cerámica común. Contamos con el perfil completo de un cuenco (Fig. 27/15) localizado en la UE 4169, muy similar a una pieza clasificada como cazuela en la memoria de las excavaciones de Lugo de Llanera (Fernández Ochoa, García Díaz y Zarzalejos, 2001, 17/22). Esta forma se correspondería con el grupo III C2 de Vaz Pinto para Sâo Cucufate (Vaz Pinto, 2003). También contamos con bordes de ollas, varias bases planas y algún fragmento de asa.

GRUPO 10. Esta producción se caracteriza por su factura a torno, la cocción reductora, las pastas duras y la presencia en la superficie de vesículas, fruto de la fusión de los desgrasantes debido a las altas temperaturas alcanzadas en la cocción ${ }^{9}$. El grupo esta representado solamente por un $2 \%$ de las cerámicas comunes y de los seis fragmentos documentados sólo uno nos indica forma (Fig. 29/11). En la muralla de Gijón y en Lugo de Llanera estos materiales aparecen asociados a estratos tardoantiguos datados a partir de mediados del siglo V. Esta producción de carácter seguramente local se mantendrá en épocas posteriores aunque sin alcanzar las altas temperaturas de cocción $\left(1.300^{\circ}\right)$ de la producción romana (Fernández Ochoa y Zarzalejos, 1997: 104).

\section{Ánforas}

Tan sólo se ha localizado en el espacio que estamos estudiando un fragmento del cuello y las dos asas de un ánfora (Fig. 13/12) identificable con las producciones de origen oriental cuya presencia se conoce cada vez mejor en el ámbito atlántico. A pesar de la fragmentación del remate del borde, la pieza podría identificarse con una forma tardía proveniente de Antioquia (Cartago 1, Keay LIII, clase 44 de Paecock y Williams) muy difundida tanto en el Mediterráneo como en las zonas atlánticas en

9 Las pastas de este grupo fueron analizadas y los resultados de composición mineralógica y temperaturas de cocción pueden ser consultados en García Guinea (1994). contextos de larga cronología desde inicios del siglo V d.C. hasta el siglo VII d.C.

En resumen, la colección cerámica estudiada constituye un conjunto muy coherente, formado por producciones que circulan durante la segunda mitad del siglo IV y primera mitad del siglo V. La presencia de TSGGT y sus imitaciones así como de producciones comunes adscritas al grupo 10 y unos exiguos restos anfóricos podrían inducirnos a amplíar el marco cronológico posiblemente hasta la segunda mitad del siglo V o inicios del VI d.C. sin que se pueda afirmar, de momento, si estos escasos materiales pertenecen al momento de pleno funcionamiento de la villa como tal, con certeza hasta mediados del siglo $\mathrm{V}, \quad \mathrm{o}$ al periodo subsiguiente cuando se aprecian modificaciones en el uso del espacio (vid. infra).

\section{Vidrios}

El conjunto de vidrios romanos recuperado en los contextos del área excavada es bastante exiguo y corresponde a piezas pertenecientes al periodo bajoimperial atribuibles, preferentemente, a cronologías del siglo IV d.C. e inicios del siglo V d.C. y de amplia difusión peninsular (Fuentes, 1990). Pese a su escaso número, el muestrario resulta relativamente diversificado y no hemos identificado tipos semejantes en las excavaciones publicadas de la ciudad de Gijón si bien podríamos constatar un predominio de bases de copas en ambos yacimientos (Fernández Ochoa, 1994, 59; Fernández Ochoa y Zarzalejos, 1997, 105).

En Veranes encontramos un borde de vaso o cuenco $\mathrm{y}$ tres platos de la forma Isings 116 variante $\mathrm{b}$ (Fig. $15 / 35$ y 28/7) (Isings, 1957) presentes en contextos del siglo IV d.C. en el área gallega (Xusto Rodríguez, 2001, 373) y en el valle del Ebro (Ortiz Palomar, 2001, 283-284). Destacan dos pies de copa de la forma Isings 111 (Fig. 20/28 y 26/16) cuya data Ortiz Palomar sitúa en el siglo IV d.C. indicando su posible procedencia del Mediterráneo central y su continuidad hasta mitad del siglo V d.C. o inicios del VI d.C. (Ortiz Palomar, 253, fig.59, 1). De cronología ligeramente anterior son los restos del asa de una jarra de la forma Isings 121 b (Fig. 20/27) procedente de Europa central y Noroccidental encontrada también en contextos del valle del Ebro (Ortiz Palomar, 181, fig.36) pero no exenta de semejanzas con las jarras conocidas en los conjuntos funerarios de la villa de la Olmeda (Abásolo et alii, 1997) y de la necrópolis de Saldaña (Abásolo, 1984). Mantenemos dudas sobre dos pequeños fragmentos de borde pertenecientes, tal vez, a una botella (Fig. 11/22) y a un ungüentario (Fig. 11/23). En este 
último caso, se trataría de una pieza del tipo Isings 104 a de larga cronología pues se constata en niveles del siglo III pero está especialmente presente en contextos de los siglos IV-V (Fuentes, 1997, 73).

\section{Metales}

Los metales recuperados en esta zona de la excavación corresponden a objetos de adorno personal y domésticos fabricados en bronce. Igualmente encontramos materiales elaborados en hierro como herramientas de trabajo y diversos elementos del mobiliario y de la sujeción de cubiertas (clavos, ganchos, escarpias) empleados en el sistema constructivo de los edificios.

\section{Objetos en bronce}

Entre las piezas metálicas destacan figura una contera decorada perteneciente a un puñal, cuya hoja se forjó en hierro y que se puede identificar con un cuchillo tipo Simancas (Fig. 20/31). El origen, la función y la difusión de este tipo de puñales ha sido ampliamente discutida en la bibliografía hispana de los años setenta (Palol, 1964; Caballero Zoreda, 1974). Asociados inicialmente y casi de forma exclusiva a las Necrópolis del Duero, los estudios de A. Fuentes demostraron la dispersión de esta variedad de cuchillo a lo largo y ancho de la geografía peninsular (Fuentes, 1989). Tampoco es sostenible su carácter militar siendo plenamente admitida su funcionalidad como cuchillo de monte en relación con los gustos venatorios del Bajo Imperio.

En Asturias, la única referencia bibliográfica a un puñal de del mismo tipo se corresponde con el hallazgo de una hoja metálica encontrada fuera de contexto arqueológico en una escombrera de las excavaciones realizadas por Uría Ríu y García y Bellido en el Castro de Coaña. La noticia fue publicada bastantes años después cuando se dieron a conocer algunos estudios de García y Bellido que aún permanecían inéditos (García y Bellido, 1984).

También se han encontrado una serie de objetos relacionados con el adorno personal elaborados en bronce. Entre ellos destacan un anillo (Fig. 20/30), una pulsera (Fig. 20/29) y dos broches de cinturón (Fig. 20/24 y 11/25). El anillo es un sencillo aro de bronce liso que en su parte superior presenta un ligero ensanchamiento con decoración incisa mientras la pulsera se compone de una lámina en bronce con decoración geométrica. Por otra parte, el broche de cinturón (Fig. 11/25) es de una tipología muy simple dentro del conjunto de broches de cinturón del Bajo Imperio profusamente decorados. Se trata de un prendedor de placa pequeña y rectangular que en este caso carece de decoración (Aurrecoechea, 2001).

En cuanto a la vajilla metálica, se han encontrado recipientes en estado muy fragmentario de los que se conservan los elementos más robustos, entre los que destaca el aplique antropomorfo de asa de situla (Fig. 16/41) que muestra como decoración figurativa un rostro humano adscribible al tipo IIb de la clasificación de Delgado (Delgado 1970). Piezas prácticamente idénticas se conocen en Conimbriga y Mérida y muy similares en la villa de La Olmeda (Palencia), Pamplona y en el castro de la Magdalena (Linares Jaen), todos con cronologías tardorromanas (Castelo Ruano et alii, 1995).

\section{Objetos en hierro}

Los objetos metálicos en hierro ocupan, sin duda, la mayor proporción dentro de los metales recuperados. Desde el punto de vista funcional, se distinguen dos grandes grupos, los relacionados con la explotación agropecuaria y los utilizados en las estructuras lígneas y en el mobiliario del edificio.

Dentro del conjunto del instrumental de uso agrícola $y$ ganadero, se ha recuperado un conjunto de herramientas formado por hojas de cuchillo, podaderas, picos, piquetas, y cencerros. Se trata de herramientas muy comunes de larga tradición documentadas también en otras villas del Bajo Imperio. Destacan por su buen estado de conservación los cencerros realizados en una fina hoja de hierro (Fig. 25/26 y 25/25) con paralelos idénticos en la tumba I de Fuentespreadas (Caballero Zoreda,1974) y en la villa romana del Arellano (Mezquíriz,, 2003), siempre en ambientes tardíos.

Los metales con una funcionalidad constructiva constituyen un amplio grupo formado por clavos, ganchos y escarpias, en su mayoría relacionados con la construcción de los armazones de madera de las cubiertas de la villa, y fragmentos de bisagras que formarían parte de las puertas y contraventanas de la edificación. La mayor concentración de estos metales esta presente en la unidades estratigráficas UE 4165 y UE 4166 que componen depósitos intencionales de tegulas procedentes del saqueo de las cubiertas del edificio.

\section{Monedas}

Durante la excavación de la puerta del complejo rural de Veranes se han recuperado cinco pequeños bronces tardorromanos acuñados por Constantino y sus familiares entre el 334 y el 354 d.C. El conjunto, 
a pesar de su limitado número de ejemplares, refleja el tipo de monetario dominante en los hallazgos de la villa, en el que son muy habituales los tipos FEL TEMP REPARATIO y GLORIA EXERCITVS. Las monedas debieron permanecer en circulación en el siglo V. Las piezas se recuperaron en contextos de uso y abandono del patio de la villa y en posición secundaria en niveles de amortización post-romana y medieval.

Los tipos FEL TEMP REPARATIO y GLORIA EXERCITVS están bien representados en la Península durante el segundo tercio del siglo IV d.C, momento caracterizado por la gran abundancia de moneda en circulación, fenómeno que se corresponde con una etapa de gran inflación entre el 335 d.C. y el 361 d.C. (Bost, Campo, Gurt, 1979:180) y, aunque dejan de emitirse durante la segunda mitad del siglo IV, continúan en los circuitos económicos en muchas zonas hasta el final de la circulación monetaria romana.

En Asturias, el monetario del siglo IV lo conocemos sobre todo por los diferentes tesorillos $\mathrm{u}$ ocultamientos localizados, en los que las labras a nombre de Constantino o de su familia, como ocurre en Veranes o Gijón, son las más abundantes (Gil Sendino, 1997:283). Estas monedas van a permanecer como el principal monetario en circulación durante todo el siglo IV y el siglo $\mathrm{V}$.

\section{Hueso y azabache}

En los niveles de abandono de la puerta de la villa que venimos analizando se han encontrado además sendas piezas de adorno personal realizadas en hueso y azabache. La primera corresponde a una alfiler de pelo (acus crinalis) incompleto y decorado con finas incisiones en retícula (Fig. 27/17). En azabache se contabiliza una cuenta de collar de sección circular y con decoración incisa (Fig. 24/24). El uso del azabache como elemento profiláctico y de adorno personal está atestiguado en la región asturiana desde el Paleolítico Superior y es frecuente el hallazgo de cuentas de collar de azabache en contextos megalíticos, castreños y medievales (Menéndez, 2003:274-275). Cuentas de este tipo se han recuperado en diferentes contextos romanos peninsulares, por ejemplo, formando parte de un collar de cuatro piezas de azabache y dos de ámbar en la necrópolis tardorromana de Albalate de las Nogueras (Cuenca) (Fuentes, 1989: 73-74).

\section{Cerámica medieval}

La clasificación de las cerámicas medievales se ha realizado atendiendo a las seriaciones establecidas por J. A. Gutiérrez González y A. Rodríguez Vázquez para el cercano yacimiento medieval de Peñaferruz (Gutiérrez González, 2003), cuya excavación ha proporcionado por vez primera en Asturias una secuencia cronoestratigráfica fiable a pesar de las dificultades que presentan siempre los conjuntos cerámicos medievales. Los porcentajes de cada grupo se reflejan en el cuadro 3

\section{Cerámica medieval por grupos}
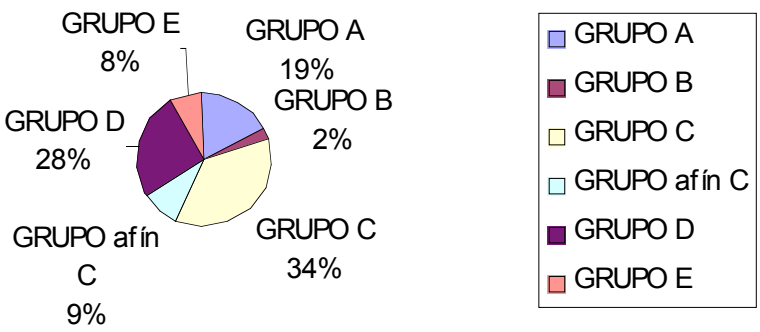

\section{CUADRO 3}

GRUPO A. Cerámica pardo-anaranjada con centro gris. Después de los grupos $\mathrm{C}$ y $\mathrm{D}$, es el grupo más numeroso de la muestra estudiada, representando el $19 \%$ del total de fragmentos de cerámica medieval. En la UE 4051 es el grupo más representativo con un $37 \%$, disminuyendo hasta un $18 \%$ en las UE 4050 y UE 1002, respectivamente. Se trata de piezas realizadas a torno lento que en ocasiones muestran digitaciones del artesano que las trabajó y una marcada huella de unión entre las bases y la pared. Morfológicamente se asocia a formas cerradas, fundamentalmente ollas y jarras de 60 a $120 \mathrm{~mm}$ de diámetro. Se caracteriza por pastas de color marrón, pardo, crema o naranja, de tonalidades claras $u$ oscuras, en las superficies y diferentes tonos de gris, predominando el gris azulado, en el centro, que se corresponden con una cocción inicial reductora y un acabado oxidante. Presenta desgrasantes heterométricos, fundamentalmente de cuarcita, siendo también numerosos los de chamota y las vacuolas, en menor cantidad aparecen los calizos, de cuarzo y férricos. En una ocasión se documenta, en la superficie exterior de una base, la impronta cruciforme de las hendiduras de la torneta. Las decoraciones se localizan en el cuerpo de la pieza, describiendo líneas y ondas simples o dobles incisas. $\mathrm{y}$, en un asa, decoración mediante punciones. 


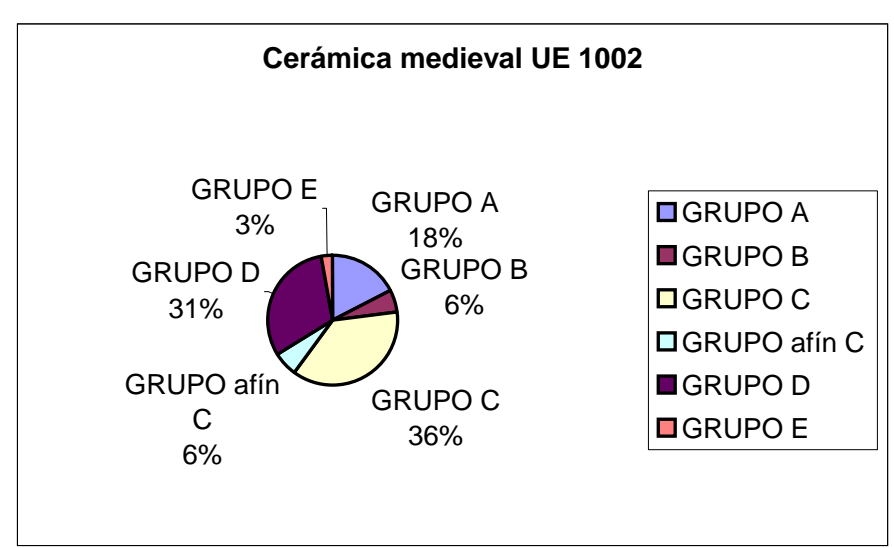

\section{CUADRO 4}

GRUPO B. Cerámica negra con centro rojo. Desde un punto de vista meramente cuantitativo este es el grupo menos importante, representando solamente el $2 \%$ de la muestra. No aparece documentado en las UUEE 4051 y 4050 y en la UE 1002 tan sólo supone un $6 \%$. La poca entidad de los fragmentos de los que disponemos no nos permiten obtener formas, a excepción de un borde y pared provenientes de un cuenco de $150 \mathrm{~mm}$. de diámetro (Fig. 8/8), por tanto y a diferencia de las formas documentadas en el resto de los grupos, se trataría de una forma abierta. El grupo B se caracteriza por piezas realizadas a torno lento con pastas de color negruzco en las superficies y centros de color rojo fruto de un ambiente de cocción inicialmente oxidante que se transforma después en reductor. Como desgrasantes se utilizan fundamentalmente caliza y cuarcita, aunque también se observan cuarzo, chamota, mica y vacuolas. La mayor parte de los fragmentos cerámicos asociados a este grupo son paredes decoradas con incisiones a peine describiendo retículas o líneas paralelas, o, en el caso del cuenco, pequeñas punciones.

GRUPO C. Cerámica gris (reductora). Es el grupo mayoritario con el $34 \%$ de los fragmentos cerámicos estudiados. Representa el $35 \%$ de las piezas cerámicas medievales de UE 4051, el 33\% de UE 4050 y el $36 \%$ de UE 1002 . Se trata de piezas hechas a torno lento que presentan en ocasiones las huellas del artesano que las modeló y una marcada línea de unión entre la base y el cuerpo de la pieza. Las formas son cerradas -ollas y jarras, predominando las primeras- de diámetros variables entre los 80 y los $154 \mathrm{~mm}$. Las pastas son gris-azuladas, aunque ocasionalmente las superficies presentan un tono blanquecino o gris y los centros pueden ser violáceos o blanquecinos. La cocción es reductora, a menudo con una postcocción oxidante. Uso de desgrasantes heterométricos de cuarcita, caliza y vacuola, en menor cuantía aparecen la mica, chamota, cuarzo y los desgrasantes férricos. Como en el resto de los grupos los fragmentos decorados se corresponden con paredes que presentan líneas u ondas realizadas mediante incisión, que arrancarían de la zona del cuello de la pieza extendiéndose por parte del cuerpo. Este grupo presenta una gran singularidad decorativa con la aparición de siete piezas pintadas. En la mayor parte de los casos se trata de bandas u ondas en zigzag de color grisáceo combinadas con pequeños puntos del mismo color, presentando una de las piezas un tratamiento de engobado anaranjado en ambas superficies previo a la aplicación de la pintura (Fig. 9/15, 9/16, 12/34, 12/35). Sólo en una ocasión se documenta una decoración pictórica diferente, líneas rectas describiendo formas en $\mathrm{V}$, quizás una especie de enrejado, de color rojo vino y $7 \mathrm{~mm}$. de grosor; esta pieza de pequeño diámetro, presenta en la superficie exterior de la base la impronta de las hendiduras de la torneta (Fig. 12/36). Las piezas pintadas tienen en común un mejor acabado de sus facturas que los observados, como tendencia general, no sólo en el grupo $\mathrm{C}$ sino en el resto de los grupos estudiados.

GRUPO AFÍN AL C. Cerámicas de cocción mixta. Hemos decidido incluir un nuevo grupo en nuestra clasificación ya que hay un reducido grupo de piezas, 9\% de la muestra, que a pesar de sus similitudes con las piezas del grupo $\mathrm{C}$ difiere de éstas en el tipo de cocción, este nuevo grupo, no obstante, hemos decidido considerarlo como una variante de aquél. Se trata de piezas trabajadas a torno lento lo que en ocasiones produce la aparición de restos de digitaciones del artesano, también se documenta en ciertos fragmentos una marcada huella de unión entre la base y la pared de la cerámica. No se pueden obtener formas. Las pastas son gris-azuladas en las superficies exteriores mientras qua las interiores y los centros de las piezas presentan tonos rosáceos o anaranjados, como resultado de una cocción inicialmente oxidante que en un momento dado se vuelve reductora. Predomina el uso de desgrasantes calizos y de cuarcita, aunque también aparecen micas, chamotas y vacuolas. La decoración, de líneas incisas, aparece en las paredes de las cerámicas.

GRUPO D. Cerámica roja (oxidante). Después del grupo $\mathrm{C}$ el $\mathrm{D}$ es el más importante con un total del $28 \%$ de los fragmentos estudiados y con un clara tendencia ascendente, así si en la UE 4051 era el tercer grupo más numeroso con un $20 \%$, en la UE 4050 ya ocupa el segundo lugar con el $26 \%$ de los fragmentos y en la UE 1002 aparece con un porcentaje semejante al grupo C, el $31 \%$ del total. Son piezas hechas a torno lento y como en otros grupos esto produce la aparición de las huellas de los dedos del artesano que modeló la cerámica, documentándose también la marca de unión entre las bases y las paredes. Formas cerradas, ollas y jarras de 
40 a $180 \mathrm{~mm}$. de diámetro, pastas naranjas y cocción oxidante, si bien posibles desajustes en la cocción o una posterior exposición a un ambiente reductor hace que en ocasiones las superficies exteriores de estas piezas adquieran un tono más oscuro, pardo o violáceo. Desgrasantes heterométricos de cuarcita, mica y chamota, en menor cantidad pueden aparecer los calizos y las vacuolas. Decoraciones de líneas u ondas simples y dobles en fragmentos de pared.

GRUPO E. Cerámica arenosa. Grupo minoritario, tan sólo el $8 \%$ de los fragmentos estudiados se enmarcan en él. Las piezas están hechas a torno lento, de aspecto grosero, con improntas digitales en la cara interna de los cuerpos. Las formas que predominan son cerradas -ollas y jarras- de 80 a $120 \mathrm{~mm}$. de diámetro. Las pastas de color crema o blanquecino, la superficie exterior de las cerámicas puede presentar un color gris o negruzco. Cocciones reductoras y reductoras irregulares con oxidaciones. Uso de desgrasantes cuarcíticos y micáceos, en menor cantidad chamotas, vacuolas y desgrasantes férricos. Decoración en las paredes de líneas incisas.

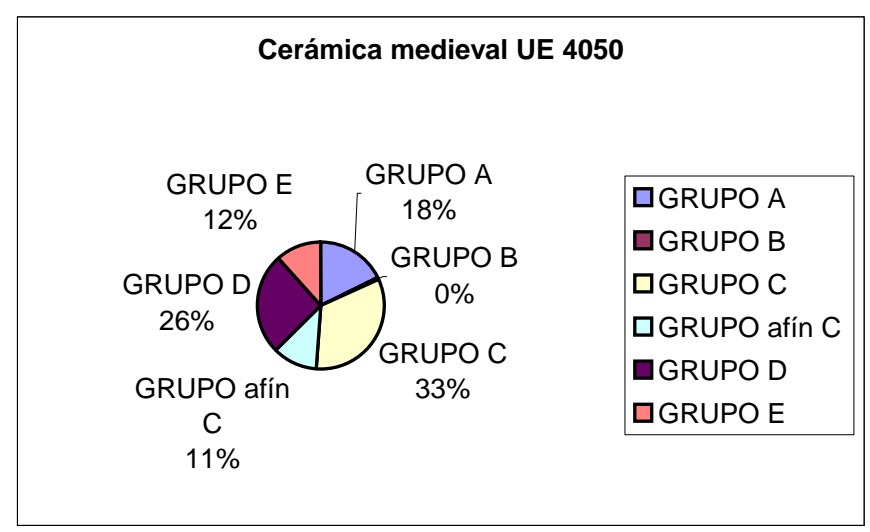

\section{CUADRO 5}

La muestra estudiada está integrada por fragmentos de pequeñas dimensiones, muy rodados, pocos de los cuales nos permiten establecer formas cerámicas de las piezas de origen, identificándose, en todos los grupos excepto el $\mathrm{B}$, ollas y jarras de diámetros que van desde los 40 a los $154 \mathrm{~mm}$. Tan sólo en una ocasión, en el grupo $\mathrm{B}$, se documenta una forma abierta perteneciente a un cuenco de $150 \mathrm{~mm}$. de diámetro. Por tanto todo el conjunto nos está mostrando un ajuar cerámico medieval poco diversificado desde un punto de vista morfológico.Los fragmentos que aparecen con restos de decoración muestran puntos, líneas, retículas u ondas realizadas mediante incisión o incisión a peine, o bien, pequeños puntos incisos obtenidos mediante punción.

Se trata pues de motivos decorativos muy simples y que se repiten en todos los grupos cerámicos. Frente a esta homogeneidad, en el grupo D se documenta además la técnica decorativa de digitaciones en los bordes y en el grupo $\mathrm{C}$ la decoración pintada de algunas vasijas. Todas las piezas están realizadas a torno lento, mostrando, algunas, digitaciones del artesano que las trabajó, siendo también frecuente la aparición de una marcada huella de unión entre las bases y la pared. Predominan las cocciones irregulares o mixtas en la mayoría de los grupos (A; $\mathrm{B}$, variante del $\mathrm{C}, \mathrm{E}$ ), incluso en los grupos $\mathrm{C}$ y $\mathrm{D}$, caracterizados por cocciones reductoras y oxidantes, respectivamente, es frecuente las variaciones de tono de las pastas como consecuencia de una variación o alteración, más o menos marcada, del ambiente de cocción. La secuencia cerámica muestra un predomino de los grupos $\mathrm{C}$ y $\mathrm{D}$ en las tres unidades estratigráficas estudiadas, representando entre ambos en torno al $62 \%$ del total de los fragmentos recuperados, el tercer grupo más numeroso sería el grupo A con un 19\%. Los grupos B, E y afín al C se encuentran menos representados $(2 \%, 8 \%$ y $9 \%$ del total, respectivamente), especialmente el $\mathrm{B}$ que aparece con carácter meramente testimonial. En la UE 4051 se localiza tan sólo el $4 \%$ de los materiales medievales estudiados, apareciendo la mayor parte de lo mismos en la UE 4050 (57\%) y el resto en la UE 1002 (39\%). La UE 4051 viene definida por la presencia del grupo A, el más cuantioso con el $37 \%$ de los fragmentos, el grupo $\mathrm{C}$ que le sigue de cerca con un $35 \%$, y el grupo $\mathrm{D}$, en tercer lugar, representando el 20\%. Apenas se documentan el resto de los grupos (E y afín al C, 3 y 5\%, respectivamente). En la unidad con mayor presencia de cerámica medieval, UE 4050, el grupo C se convierte en el grupo más numeroso con un $33 \%$ de las piezas y el grupo D en el segundo con el $26 \%$, disminuyendo el peso específico del grupo A (18\%) y aumentando considerablemente la presencia de los grupos $\mathrm{E}$ y afín al C (12 y $11 \%$, respectivamente) que no obstante siguen siendo minoritarios. En la UE 1002 , se mantiene la misma tónica que la observada en la UE 4050, los grupos A, C y D mantienen un porcentaje similar aunque los dos últimos lo aumentan ligeramente $(18,36$ y $31 \%$, respectivamente), los grupos $\mathrm{E}$ y afín al $\mathrm{C}$, mantienen una pequeña presencia ( 3 y $6 \%$, respectivamente) y como novedad se documenta el grupo B (6\%). 


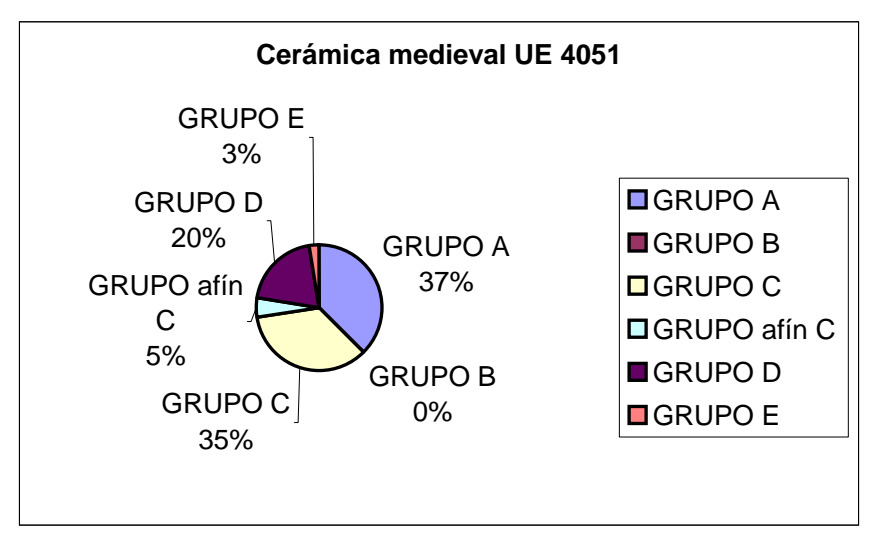

\section{CUADRO 6}

En resumen, la colección de cerámica medieval guarda una gran coherencia con los materiales documentados para esta misma época en el entorno de Gijón y especialmente con los de la fortaleza de Peñaferruz (Gutiérrez González, 2003:201-204). Las unidades medievales parecen formarse a partir del siglo IX aunque las características del grupo cerámico nos llevan a momentos avanzados del Medievo, siglos XII y XIII que se corresponderían con la tercera fase de Peñaferruz (Gutiérrez González, 2003:201).

\section{La transformación de la villa tardorromana: cambio y continuidad}

De acuerdo con los datos presentados en los apartados precedentes, la secuencia de ocupación del área excavada indica que la villa estuvo en pleno funcionamiento, al menos, hasta mediados del siglo V d.C.. La dinámica histórica que se desprende de la información arqueológica refrenda una amortización rápida del espacio de la puerta y sus entornos sin señal alguna de violencia. Las semejanza del patrón material con el obtenido en otros asentamientos rurales tardorromanos hispanos permite situar a la villa de Veranes dentro de un fenómeno de relativa homogeneidad productiva y comercial que denota un trasfondo común a pesar de la diversidad del lugares y contextos.

La alteración del funcionamiento de, al menos, una parte del complejo, debe situarse a partir de mediados del siglo $\mathrm{V}$ d.C. que es cuando se advierte el primer síntoma de cambio en la utilización del espacio con la presencia de enterramientos fechados entre los siglos $\mathrm{V}$ y VI d.C. ocupando habitaciones del edificio señorial. En efecto, en la estancia E10 hemos documentado un enterramiento infantil (T 401) que rompe el pavimento de opus signinum. La deposición se realizó en el interior de un gran recipiente cerámico tardorromano, y los análisis de los restos óseos arrojan la fecha de 395-564 $(94.3 \%)^{10}$. Este hecho pone de relieve el uso del citado ambiente como espacio funerario. En la misma unidad estratigráfica y rompiendo también el pavimento de la habitación se localizó otra tumba infantil (T 125) confeccionada con dos ímbrices y orientada al norte $^{11}$. Sobre este primer nivel de necrópolis se registró un nuevo nivel cementerial de tumbas de lajas. La presencia de los dos enterramientos parece coincidir cronológicamente con la data de los materiales asociados a la etapa de abandono de la zona de la puerta y con el fin del uso de un basurero situado extramuros, junto al acceso principal de la villa $^{12}$.

Estos testimonios podrían significar el abandono total o parcial de la villa, dato cuyo alcance todavía no se puede constatar fehacientemente mientras prosiguen las excavaciones. No obstante, podrían considerarse marcadores de una transformación parcial del espacio de la villa quizá asociado un cambio en la propiedad del fundus pero, en todo caso, su presencia indica el comienzo de una discontinuidad cultural progresiva.

Antes de que las fuentes medievales hablen de la existencia en el siglo IX de la iglesia de San Pedro y Santa María de Veranes (Fernández Ochoa et alii, 1998) instalada en una estancia de la propia villa (M1), contamos con otro dato de interés sobre la fase tardoantigua del yacimiento y el proceso de transición al Medievo. En la habitación E17 se han excavado dos tumbas de lajas orientadas norte-sur atribuibles por la datación de C-14 entre mediados del siglo VII y el último tercio del siglo VIII $^{13}$ y registrándose el uso del espacio como área metalúrgica entre estas fechas y el siglo X. Asimismo durante la campaña de 2003 se han constatado, en el patio septentrional de la villa, aún en proceso de excavación, abundantes agujeros de poste y el negativo de una estructura de tendencia circular de materiales lígneos conservada parcialmente. Los datos provisionales obtenidos en la zona indican que estas estructuras, posiblemente de hábitat, corresponden a un momento altomedieval, hecho cada vez mejor documentado en los yacimientos

${ }^{10}$ Ua-20550

${ }^{11}$ En este caso desgraciadamente no se conservaban restos óseos.

${ }^{12}$ En este contexto se recuperaron, entre otros materiales, varios fragmentos de TSHT 37 decorada con círculos secantes, instrumentos agrícolas de hierro de típica tipología tardorromana y varios ejemplares de cuchillos tipo Simancas. El material del basurero extramuros coincide con el analizado en este estudio.

13 Tumba 106: Ua18098 y Ua20552, 660-775 (95.4\%). En la U.E. a la que pertenecen estos enterramientos no se encontró ningún tipo de material arqueológico. 
excavados en los últimos años (Azcarate y Quirós, 2001).

De manera paulatina y en torno al centro religioso, se fue desarrollando el cementerio, que se mantuvo en funcionamiento hasta el siglo XIV. Los materiales cerámicos asociados a los suelos de uso de la necrópolis y la recuperación de más de treinta monedas emitidas entre los siglos XIII y XIV vinculadas al último momento de las inhumaciones, sugieren el final de la ocupación a lo largo del siglo XIV, cuando la iglesia había dejado de tener culto. De la necrópolis medieval se han excavado más de 500 tumbas. El cementerio mantiene, en líneas generales, las características tipológicas y rituales, con variaciones en la orientación, de los enterramientos cristianos de época medieval (Riu y Bolòs, 1982; Campos, 1997).

A pesar del proceso de fragmentación espacial de la villa de Veranes, iniciado en algún momento de la segunda mitad del siglo V o a inicios del siglo VI, la secuencia ocupacional continúa hasta el siglo XIV. Las escalas precisas de estas transformaciones deben vincularse a fenómenos de evolución en los sistemas de poder y fiscalidad dentro del ámbito rural que repercutió en la organización de tierras y propiedades $\mathrm{y}$, en definitiva, en la modalidad de explotación del territorio. La presencia creciente de la Iglesia en el ámbito rural contribuyó de manera definitiva a la crisis de la vieja aristocracia y a la emergencia de nuevas élites poderosas vinculadas a la nueva religión y sin duda, a nuevos ambientes militares tras la definitiva retracción del Estado romano. Resulta tentador pensar que los indicios de ruina y progresivo abandono de la villa de Veranes junto con la aparición de las primeras inhumaciones detectadas en algunas las estancias de la zona señorial, se corresponden con la conversión del área meridional de la villa en lugar de culto en torno a una primitiva iglesia que ocuparía el espacio del antiguo oecus/triclinium (M-1) y las habitaciones adyacentes. El papel centralizador del territorio detentado por el enclave tardorromano romano se mantendría pero ahora en manos de un nuevo poder emergente de signo eclesiástico. 


\section{BIBLIOGRAFÍA}

Abásolo, J.A. (1984): Excavaciones en el yacimiento de la Morterona (Saldaña, Palencia), Palencia.

Abásolo, J.A. et alii (1997): La necrópolis norte de la Olmeda (Pedrosa de la Vega, Palencia), Palencia.

Alarçao, A. (1994): Coleçoes, Museo Monográfico de Conímbriga, Lisboa

Aurrecoechea, J. (2001): Los cinturones romanos en la Hispania del Bajo Imperio, Madrid.

Azkarate, A., Quirós, J.A. (2001): “Arquitectura domestica Altomedieval en la península ibérica. Reflexiones a partir de las excavaciones arqueológicas de la catedral de Santa María de Vitoria-Gasteiz (País Vasco)", Archeologia Medievale, XXVIII, 25-60

Bost, J.-P; Campo, M.; Gurt, J. M., (1979), "La circulación monetaria en Hispania durante el período romano imperial: problemática y conclusiones generales", Simposio Numismático de Barcelona II. Barcelona, 174202

Brogiolo, G. P. (ed.) (1996): La fine delle ville romane: transformación nelle champagne tra tarda Antiquitè e alto Medioevo. 1995. Documenti Archeologia, 11, Mantua.

Caballero, L. (1974): La necrópolis tardorromana de Fuentes Preadas (Zamora). Un asentamiento tardorromano en el valle del Duero, EAE, 80, Madrid.

Campos, V. (1997): "Las sepulturas medievales. Introducción a su estudio práctico", Acta Medievalia, 18, Barcelona, 526-544,.

Castelo Ruano, R., Gómez Ramos, P., Torrecilla Aznar, A.; Arribas Domínguez, R.; Panizo Arias, I. (1995): "Apliques de asa de situlae con decoración antropomorfa procedentes de la villa romana del Saucedo (Talavera La Nueva, Toledo)", CuPAUAM, 22, Madrid, 125-164.

Chavarría, A. (2001): Poblamiento rural en el territorium de Tarraco durante la Antigüedad tardía. Arqueología y territorio medieval, 8, Jaén, 55-76.

Delgado, M. (1970): "Elementos de sítulas de bronze de Conimbriga", Conimbriga, 9, Coimbra, 1543

Fernández Ochoa, C. (1994): Una industria de salazones en época romana en la Plaza del Marqués, Gijón.
Fernández Ochoa, C. (1997): La muralla romana de Gijón (Asturias), Gijón.

Fernández Ochoa, C. (2003): El lenguaje de las piedras. La recuperación del Patrimonio arqueológico de Gijón, Gijón.

Fernández Ochoa, C., García, P. y Uscatescu, A. (1992): "Gijón en el período tardoantiguo: cerámicas importadas de las excavaciones de Cimadevilla". AEspA, 65, Madrid, 105-149.

Fernández Ochoa, C.; García, P. y Zarzalejos, M. (2001): Excavaciones arqueológicas en Santa María de Lugo de Llanera (Asturias). Memoria de las campañas de 1991 a 1995, Oviedo.

Fernández Ochoa, C., Gil Sendino, F. et alii, (1998): "Proyecto Veranes. Arqueología e Historia en torno a la vía de la Plata en el concejo de Gijón (Asturias)", CUPAUAM, 24, Madrid, 253-278.

Fernández Ochoa, C. y Gil Sendino, F., (1999): "Excavaciones arqueológicas en el yacimiento romano y medieval de Veranes (Cenero).Campañas de 1997 y 1998", EAAsturias, Oviedo, 175-186.

Fernández Ochoa, C. y Gil Sendino, F., (e.p.): “El Torrexón de Veranes. Reflexiones sobre la transición al Medievo en Asturias", EAAsturias, Oviedo.

Fernández Ochoa, C. et alii, (2004): "Estudio y proyecto de recuperación del ramal transmontano de la Ruta de la Plata en el concejo de Gijón (Asturias)", VII jornadas andaluzas de difusión del Patrimonio Histórico, Huelva, 173-186.

Fernández Ochoa, C. et alii, (2005): "El proyecto "Ruta de la Plata" en el Concejo de Gijón (Asturias)", Arqueología militar romana en Europa, Segovia, 103-116.

Fernández Ochoa, C; Gil Sendino, F. y Orejas, A. (2004): "La villa romana de Veranes. El complejo rural tardorromano y propuesta de estudio del territorio", AEspA, 77, Madrid, 197-219

Fernández Ochoa, C. y Morillo Cerdán, A. (2005): La Arqueología Hispanorromana a finales del siglo XX. Bibliografía temática y balance historiográfico. Madrid

Fuentes, A. (1989): La necrópolis tardorromana de Albalate de las Nogueras (Cuenca) y el problema de las denominadas necrópolis del Duero, Cuenca. 
Fuentes, A. (1997): "El vidrio romano", Vidrios del Puig del Molins (Eivissa). La colección de D. José Costa “Picadol” , Ibiza, 57-86.

García y Bellido, A. (1984): "Puñales tardorromanos de Lancia y Coaña", AEspA, 57, Madrid, 179182.

Gil Sendino, F (1997): "Numismática”, en Fernández Ochoa, C. (1997): La muralla romana de Gijón (Asturias). Gijón.

Gil Sendino, F (2002): "Veranes", Diccionario Histórico de Asturias, La Nueva España, Oviedo, 943-945

García, R. (1994) "Análisis de cerámicas”, en Fernández Ochoa, C. (1994). Una industria de salazones de época romana en la plaza del Marqués, Gijón, 205-214

García Guinea, M.A. (dir.) La villa romana de Quintanilla de la Cueza (Palencia) Memoria de excavaciones 1970-1981. Palencia.

Gutiérrez González, J. A. (2003): Peñaferruz (Gijón). El castillo de Curiel y su territorio, Gijón.

Juan Tovar, L.C. (2000): "La terra sigillata de Quintanilla de la Cueza”. En García Guinea M. A (dir.) La villa romana de Quintanilla de la Cueza (Palencia) Memoria de excavaciones 1970-1981, Palencia, 45-122.

López Rodríguez, J. (1985): Terra sigillata hispánica tardía decorada a molde de la Península Ibérica, Salamanca.

Martínez Salcedo, A. (2004): La cerámica común de época romana en el País Vasco, Vitoria.

Menéndez Menéndez, A. (2003): “Azabache”. En Gutiérrez González, J.A. (2003): Peñaferruz (Gijón). El castillo de Curiel y su territorio, Gijón.

Mezquiriz, M.A. (1985): “Terra sigillata hispánica”, EAA, Atlante delle forme ceramiche II, Roma, 93-183

Mezquíriz, M.A. 2003: La villa romana de Arellano, Pamplona

Palol, P. (1964): "Cuchillo hispanorromano del s. IV d.C.", BSEAA, 30, Valladolid, 67-102.

Palol, P. y Cortés, J. (1974): La villa romana de la Olmeda (Pedrosa de la Vega, Palencia). Excavaciones de 1969 y 1970, AAH, 7, Madrid.

Ortiz Palomar, E. (2001): Vidrios procedentes de la provincia de Zaragoza. El Bajo Imperio Romano, Zaragoza.
Riu, M. y Bolòs, J. (1982): “Observacions metodològiques, esquemes i fixes de treball per a l'estudi de les espultures", Necrópolis $i$ sepultures medievals de Catalunya, Acta Mediaevalia, Annex 1, Barcelona.

Uscatescu, A, Fernández Ochoa, C. y García, P. (1994): "Producciones atlánticas de terra sigillata gálica tardía en la costa cantábrica de Hispania”. CUPAUAM, 21, Madrid, 183-233.

Vaz Pinto, I. (2003): A cerámica comun das villae romanas de Sao Cucufate (Beja). Lisboa.

Vegas, M. (1973): Cerámica común romana del Mediterraneo Occidental, Barcelona.

Xusto Rodríguez, M. (2001): O vidrio provincial galaicoromano, Vigo. 


\section{INVENTARIO DE MATERIALES}

\section{UE 1002}

\section{Terra Sigillata}

1. T.S.H.T. Fragmento de borde. Forma 74/Palol 4. P: N 35 decantada con desgrasantes calizos de grano fino. B: no conserva. Descripción: borde horizontal de sección rectangular con decoración incisa en zigzag. Diám: 150 mm. (nº 4.608/1)

\section{Cerámica común romana}

2. Fragmento de borde exvasado de labio ligeramente engrosado. Torno, cocción mixta, pastas grises y anaranjadas con desgrasantes micáceos de grano fino y cuarcíticos de grano medio, Superficie alisada. Diám: 100 mm. GRUPO 1(nº 4.604/1)

3. Fragmento de borde oblicuo ligeramente invasado y labio engrosado. Torno, cocción reductora de pastas grises y ocres con abundantes desgrasantes calizos y cuarcíticos distribuidos homogéneamente. Superficie alisada. GRUPO 2 (n $\mathrm{n}^{\circ}$ 4.604/2)

4. Fragmento de borde exvasado de labio redondeado con acanaladura. Torno, cocción oxidante con pastas anaranjadas con desgrasantes calizos, cuarcíticos y micáceos de grano fino y medio. Diám: 11,4. GRUPO 3 (n 4.604/4)

5. Fragmento de borde exvasado de labio redondeado. Torno lento, cocción irregular de pastas grises, pardas y ocres con abundantes desgrasantes cuarcíticos y micáceos de grano medio y grueso, superficie sin tratar. GRUPO $6\left(n^{\circ} 4.604 / 3\right)$

\section{Cerámica medieval.}

6. Fragmento de pared y borde de jarra. Borde exvasado con labio de sección triangular. Torno lento. Cocción reductora con postcocción o enfriamiento oxidante. Pasta marrón en ambas superficies, centro grisáceo. Desgrasantes heterométricos de cuarcíticos, micáceos y chamota. Diám. 60 mm. GRUPO A. (n $\left.{ }^{\circ} 4602 / 14\right)$.

7. Fragmento de pared y base de olla o jarra. Torno lento. Cocción oxidante con postcocción o enfriamiento reductor. Pasta crema en la superficie interior, gris clara la superficie exterior. Desgrasantes heterométricos de micáceos y cuarcíticos. Presenta digitaciones. Diám. 90 mm. GRUPO A. (nº 4602/7).

8. Fragmento de base. Torno lento. Cocción oxidante con inicio reductor. Pasta rosada clara, el centro presenta un tono gris claro. Desgrasantes heterométricos cuarcíticos, calizos y vacuolas. Esta pieza aparece recortada, probablemente se reutilizó como tapadera. Diám. $84 \mathrm{~mm}$. GRUPO A. $\left(\mathrm{n}^{\circ}\right.$ 9328/1).
9. Fragmento de pared y borde de cuenco. Borde invasado. Torno lento. Cocción oxidante con postcocción reductora. Pasta negruzca en ambas superficies, centro rojo. Desgrasantes heterométricos de cuarzo, cuarcita y caliza. Decoración de puntos incisos. Diám. 150 mm. GRUPO B (nº 4602/1)

10. Fragmento de pared y borde de jarra. Borde ligeramente exvasado con labio de sección redondeada. Torno lento. Cocción reductora con postcocción o enfriamiento oxidante. Pasta grisazulada. Desgrasantes heterométricos cuarcíticos y vacuolas. GRUPO C. ( $\left.n^{\circ} 4602 / 2\right)$.

11. Fragmento de pared y borde de olla. Borde exvasado de sección redondeada. Torno lento. Cocción reductora con postcocción o enfriamiento oxidante. Pasta gris-azulada oscura. Desgrasantes heterométricos cuarcíticos, micáceos y vacuolas. Diám. 130 mm. GRUPO C. (n 4602/6).

12. Fragmento de pared y borde de jarra. Borde exvasado de sección redondeada. Torno lento. Cocción reductora. Pasta gris-azulada oscura. Desgrasantes de grano fino y medio de caliza, vacuola, chamota y cuarcíticos. Decoración incisa, a peine, que arranca desde el cuello hasta la panza de la pieza. GRUPO C. (n $\left.\mathrm{n}^{\circ} 4602 / 19\right)$.

13. Fragmento de asa de jarra. Torno lento. Cocción reductora. Pasta gris-azulada oscura. Desgrasantes heterométricos cuarcíticos, calizos y vacuolas. GRUPO C. (nº 4602/12)

14. Fragmento de pared. Torno lento. Cocción reductora con postcocción o enfriamiento oxidante. Pasta gris-azulada clara, la superficie exterior presenta un tono rosado claro. Desgrasantes heterométricos cuarcíticos y calizos. Decoración de onda incisa. GRUPO C. ( $\mathrm{n}^{\circ}$ 4602/29).

15. Fragmento de pared y borde de olla. Borde exvasado de sección redondeada. Torno lento. Cocción reductora con postcocción o enfriamiento oxidante. Pasta gris-azulada clara. Desgrasantes heterométricos calizos, cuarcíticos y vacuolas. Presenta engobado de color anaranjado en ambas superficies, más intenso en la exterior donde se documenta decoración pintada mediante una banda negruzca horizontal que recorre el borde de la pieza, un poco más abajo, bandas en zig-zag, paralelas, con puntos entre ellas, de tonos grises oscuros, la banda negruzca parece superponerse ligeramente sobre el motivo decorativo. GRUPO C. (nº 9336/2).

16. Fragmento de pared. Realizado a torno lento. Cocción reductora. Pasta gris-azulada clara, la superficie interior presenta una aguada anaranjada. Desgrasantes de grano fino calizos, chamota $y$ cuarcíticos. Decoración pintada, tono grisáceo 
oscuro, describe motivos geométricos, bandas en zigzag paralelas con puntos entre ellas. GRUPO C. $\left(\mathrm{n}^{\circ}\right.$ 9336/1).

17. Fragmento de pared y borde de olla. Borde muy exvasado de sección triangular. Torno lento. Cocción oxidante. Pasta naranja en las superficies, crema oscura en el centro. Desgrasantes heterométricos cuarcíticos, calizos, micáceos vacuolas y chamota. Diám. 180 mm. GRUPO D. (nº 4602/42).

18. Fragmento de pared y borde de olla. Borde exvasado con labio de sección triangular. Torno lento. Cocción oxidante con postcocción o enfriamiento reductor. Pasta anaranjada oscura, la superficie exterior presenta zonas negruzcas probablemente debidas a una posterior exposición de la pieza al fuego. Desgrasantes heterométricos cuarcíticos, calizos, micáceos, vacuolas y chamota. Decoración en el borde de la pieza mediante digitación. Diám. 100 mm. GRUPO D. (n 4602/43).

\section{UE 4050}

\section{Terra sigillata}

1. T.S.H. Fragmento de borde. Forma Drag. 36. P: M 25 muy decantada con desgrasantes calizos de granulometría muy fina. B: R 19. Descripción: borde exvasado de labio redondeado. Diám: $170 \mathrm{~mm}$. $\left(\mathrm{n}^{\circ}\right.$ $11.135 / 1)$

2. T.S.H. Fragmento de borde. Forma Drag. 35. P: M 37 muy decantada con desgrasantes calizos muy finos. B: R 15. Descripción: borde recto de labio vuelto. Diám: 100 mm. (n 11.135/6)

3. T.S.H. Fragmento de borde. Forma Drag. 15/17. P: M 47 decantadas con desgrasantes calizos de grano fino. B: S 19. Descripción: borde oblícuo de labio resondeado ligeramente engrosado al exterior. Diám: 140 mm. (n 11.135/11)

4. T.S.H. Fragmento de borde. Forma indeterminada. P: M 37 decantadas con desgrasantes calizos de grano fino B: R 13 mal conservado. Descripción: Borde vuelto de labio redondeado. Diám: indeterminado ( $\left.\mathrm{n}^{\circ} 11.135 / 9\right)$

5. T.S.H. Fragmento de borde. Forma Drag. 35. P: M 37 muy decantada con desgrasantes calizos de granulometría fina. B: R 20. Descripción: borde exvasado de labio vuelto decorado con barbotina. Diám. 84 mm (n 11.135/7)

6. T.S.H.T. Fragmento de base. Forma indeterminada. P: M 35 muy decantada con desgrasantes calizos de grano fino. B: no conserva. Descripción: Base plana con umbo decorado en el fondo con motivo estrellado,.Diám: $20 \mathrm{~mm}$. $\left(\mathrm{n}^{\circ}\right.$ $11.135 / 13$ )
7. T.S.H.T. Fragmento de borde. Forma 8/Palol 10.

P: M 39 muy decantada con desgrasantes calizos de grano fino. No conserva barniz. Descripción: borde recto de sección apuntada. Diám: $100 \mathrm{~mm}\left(\mathrm{n}^{\circ}\right.$ $11.136 / 1)$

8. T.S.H.T. Fragmento de pared. Forma indeterminada. P: N 25 con desgrasantes calizos y micáceos de grano fino y alguno cuarcítico de grano medio. B: no conserva. Descripción: fragmento de pared decorada con series de espiguillas. $\left(\mathrm{n}^{\circ}\right.$ $11.136 / 6)$

9. T.S.G.G.T. Fragmento de borde. P: M 73 decantadas con desgrasantes calizos y cuarcíticos de grano muy fino. B: no conserva. Descripción: borde recto de sección cuadrangular. Diám: $50 \mathrm{~mm}$. $\left(\mathrm{n}^{\circ}\right.$ $11.138 / 1)$

10. T.S.G.G.T. Fragmento de asa. Forma indeterminada. P: P 92 decantadas con desgrasantes calizos de grano fino. B: no conserva. Descripción: asa de cinta moldurada. $\left(\mathrm{n}^{\mathrm{o}} 11.138 / 3\right)$

\section{Cerámica común romana}

11. Dos fragmentos de borde horizontal de sección triangular, perteneciente a una olla. Torno lento, cocción irregular de pastas grises, ocres y pardas con abundantes desgrasantes calizos y cuarcíticos regularmente repartidos, presenta decoración incisa de líneas concéntricas en el borde. Superficie alisada. Diám: 130 mm. GRUPO $2\left(n^{\circ} 11.140 / 5\right)$

12. Tres fragmentos de borde exvasado de labio redondeado. Torno, cocción oxidante de pastas pardas y anaranjadas con abundantes desgrasantes calizos y cuarcíticos de grano fino $\mathrm{y}$ medio homogéneamente repartidos. Superficie alisada. Diám.: 140 mm GRUPO 2. (nº 11.134/22)

13. Fragmento de borde exvasado de engrosado al interior. Torno, cocción irregular de pastas pardas y grises con abundantes desgrasantes calizos y cuarcíticos de grano medio regularmente repartidos. Superficie alisada. Diám. $190 \mathrm{~mm}$. GRUPO 2. $\left(\mathrm{n}^{\circ}\right.$ 11.134/29)

14. Fragmento de base plana. Torno, cocción mixta, pastas pardas y anaranjadas con abundantes desgrasantes calizos y cuarcíticos de grano medio regularmente repartidos. Decoración incisa, Diámetro $90 \mathrm{~mm}$. GRUPO 2. ( $\left.\mathrm{n}^{\mathrm{o}} 11.134 / 33\right)$

15. Fragmento de borde horizontal de labio redondeado. Torno, cocción irregular. Pastas pardas y negras con abundantes desgrasantes calizos, cuarcíticos y micáceos de grano medio. Superficie someramente alisada. Diámetro: $120 \mathrm{~mm}$. GRUPO 3. $\left(\mathrm{n}^{\mathrm{o}} 11.140 / 2\right)$ 
16. Fragmento de borde exvasado de labio apuntado perteneciente a una olla. Torno, cocción irregular de pastas ocres y grises con abundantes desgrasantes calizos y cuarcíticos de grano medio. Superficie alisada. Diám: 130 mm. GRUPO 3. (nº 11.134/3)

17. Fragmento de borde horizontal. Torno, cocción irregular de pastas ocres y grises con abundantes desgrasantes calizos, cuarcíticos y micáceos de grano fino, medio y grueso. Superficie alisada. Diám: 110 mm. GRUPO 3. ( $\left.\mathrm{n}^{\circ} 11.134 / 4\right)$

18. Fragmento de borde exvasado de labio apuntado y biselado. Torno, cocción mixta de pastas pardas y anaranjadas con desgrasantes calizos y cuarcíticos de grano medio, superficie alisada. Diám: $140 \mathrm{~mm}$. GRUPO 3. ( $\left.{ }^{\circ} 11.134 / 10\right)$

19. Fragmento de borde exvasado de labio redondeado. Torno, cocción irregular, pastas ocres, pardas y grises con abundantes desgrasantes micáceos de grano fino, medio y grueso y calizos de grano fino. Superficie alisada. Diám: $120 \mathrm{~mm}$ GRUPO 6. ( $\left.{ }^{\circ} 11.134 / 27\right)$

\section{Cerámica romana pintada}

20. Fragmento de borde oblicuo de labio redondeado. Torno, cocción oxidante, pastas naranjas con desgrasantes calizos y cuarcíticos de grano fino. Superficie alisada. Presenta pintura roja en el labio y franja negra al exterior del labio. $\left(\mathrm{n}^{\circ} 11.150 / 1\right)$

\section{Latericio}

21. Tapadera de latericio recortado. Diám. $52 \mathrm{~mm}$. $\left(\mathrm{n}^{\circ} 10.945\right)$

\section{Vidrio}

22. Frag. de un posible ungüentario o ampolla. Vidrio verde traslúcido. Diám.50 mm. Forma Isings 104 b. $\left(\mathrm{n}^{\mathrm{o}} 10.942\right)$

23. Frag. de borde de una botella o ampolla. Vidrio incoloro traslúcido. El borde es recto con el labio ligeramente redondeado. Diám.540 mm. Forma Isings 104 a. $\left(n^{\circ} 14.746\right)$

\section{Metal}

24. Placa de cinturón. Presenta un remate recto y de mayor grosor en su zona proximal, en su zona central muestra un orificio central de gran tamaño. Su zona distal es de mayor anchura y se remata con tres orificios, posiblemente para sujetar la pieza al cuero del pantalón. En uno de los orificios se conserva un remache en bronce. Conserva un posible hebijón sencillo e incompleto formado por un vástago rectangular. $\left(\mathrm{n}^{\mathrm{o}} 10950\right)$

25. Placa de cinturón. Bronce. Placa doblada en "u" en su zona proximal. Conserva un orificio para sujetar la pieza al cuero del cinturón. En su zona distal presenta un ligero ensanche. $\left(\mathrm{n}^{\mathrm{o}}\right.$ 14745)

\section{Cerámica medieval.}

26. Dos fragmentos de pared y borde de olla. Borde exvasado con labio de sección triangular. Torno lento. Cocción reductora con acabado oxidante. Pasta gris-azulada clara en el centro, anaranjada, más o menos intensa, en las superficies. Desgrasantes de grano fino y medio cuarcíticos y micáceos. Diám. $120 \mathrm{~mm}$. GRUPO A. (n 11132/91).

27. Fragmento de pared y borde de olla. Borde exvasado con labio de sección triangular. Torno lento. Cocción reductora con postcocción o enfriamiento oxidante. Pasta gris-azulada oscura. Desgrasantes de grano fino y medio de cuarcíticos, chamota, caliza y vacuola. Diám. $90 \mathrm{~mm}$. GRUPO C. $\left(\mathrm{n}^{\mathrm{o}} 11132 / 1\right)$.

28. Fragmento de pared y borde de olla. Borde exvasado con labio de sección triangular. Torno lento. Cocción reductora con postcocción o enfriamiento reductor. Pasta gris-azulada clara. Desgrasantes de grano fino y medio de vacuolas, calizos y cuarcíticos. Diám. $80 \mathrm{~mm}$. GRUPO C. $\left(\mathrm{n}^{\circ}\right.$ 11132/2).

29. Fragmento de pared y borde de olla. Borde exvasado de sección triangular. Torno lento. Cocción reductora con postcocción o enfriamiento oxidante. Pasta gris-azulada oscura. Desgrasantes de grano fino y medio de cuarcíticos y vacuolas. GRUPO C. $\left(\mathrm{n}^{\circ}\right.$ 11132/5).

30. Fragmento de pared y borde de olla. Borde exvasado de sección redondeada. Torno lento. Cocción reductora. Pasta violácea oscura en el centro, gris-azulada oscura en las superficies. Desgrasantes heterométricos cuarcíticos, calizos, férricos y vacuolas. El borde presenta una digitación a modo de decoración. Diám. $110 \mathrm{~mm}$. GRUPO C. $\left(\mathrm{n}^{\circ}\right.$ 11132/26).

31. Fragmento de pared y base. Torno lento. Cocción reductora. Pasta gris-azulada clara, la superficie exterior presenta un tono más rosado. Desgrasantes heterométricos cuarcíticos y calizos. Diám. $100 \mathrm{~mm}$. GRUPO C. ( $\left.{ }^{\circ} 11132 / 57\right)$.

32. Fragmento de pared y base. Torno lento. Cocción reductora. Pasta gris clara, gris-azulada clara en la superficie exterior. Desgrasantes heterométricos cuarcíticos, calizos y micáceos. Presenta huellas de digitaciones en las superficie interior de la pieza. Diám. 70 mm. GRUPO C. (nº 11132/58).

33. Fragmento de pared y base. Torno lento. Cocción reductora. Pasta gris-azulada. Desgrasantes de grano 
fino y medio cuarcíticos y vacuolas. Diám. $70 \mathrm{~mm}$. GRUPO C. ( $\left.\mathrm{n}^{\circ} 11132 / 62\right)$.

34. Fragmento de pared. Torno lento. Cocción reductora con postcocción o enfriamiento oxidante. Pasta gris-azulada clara, la superficie interior presenta una especie de aguada anaranjada, la superficie exterior un tono rosado. Desgrasantes de grano fino y medio cuarcíticos y calizos. Decoración pintada a base de puntos negros. GRUPO C. $\left(\mathrm{n}^{\mathrm{o}}\right.$ 11142/1).

35. Fragmento de pared. Torno lento. Cocción reductora con postcocción o enfriamiento oxidante. Pasta gris-azulada clara, la superficie interior presenta una especie de aguada anaranjada, la superficie exterior un tono rosado. Desgrasantes de grano fino y medio cuarcíticos y calizos. Decoración pintada a base de puntos negros combinados con una onda de las mismas características. GRUPO C. $\left(\mathrm{n}^{\circ}\right.$ 11142/2).

36. Fragmento de pared y base. Torno lento. Cocción reductora. Pasta gris-azulada clara. Desgrasantes de grano fino y medio cuarcíticos y calizos. Decoración pintada mediante líneas rectas en $\mathrm{V}$ de color rojo vino y $7 \mathrm{~mm}$. de grosor. Presenta digitaciones en la superficie interior de la pieza y marca en forma de cruz en la superficie exterior de la base así como marca de unión entre la base y la pared. Diám. 50 mm. GRUPO C. (nº 11142/3).

37. Fragmento de pared y borde de olla. Borde exvasado con labio de sección triangular. Torno lento. Cocción reductora con un intervalo oxidante intermedio. Pasta gris-rosada clara en el centro, grisazulada oscura en las superficies. Desgrasantes de grano fino y medio cuarcíticos y vacuolas. Diám. 80 mm. GRUPO AFÍN AL C. (nº 11132/67).

38. Dos fragmentos de pared y borde de olla. Borde ligeramente exvasado de sección redondeada. Torno lento. Cocción oxidante con acabado reductor. Pasta rosada en el centro y en la superficie interior, grisazulada oscura en la superficie exterior. Desgrasantes de grano fino y medio cuarcíticos, calizos, férricos y vacuolas. Diám. $100 \mathrm{~mm}$. GRUPO AFÍN AL C. $\left(\mathrm{n}^{\circ}\right.$ $11132 / 69)$.

39. Fragmento de pared y base. Torno lento. Cocción oxidante con momentos reductores. Pasta rosada en la superficie interior, rosada-violácea en la superficie exterior y centro. Desgrasantes heterométricos calizos, cuarcíticos y vacuolas. Presenta marca de unión entre la base y la pared y digitaciones. Se documenta un pequeño agujero de $8 \mathrm{~mm}$. en la pared de la pieza por lo que podría tratarse de algún tipo de recipiente para la decantación de líquidos, quizás una quesera. Diám. 110 mm. GRUPO AFÍN AL C. $\left(n^{\circ}\right.$ 11132/9).

40. Fragmento de pared y borde de olla. Borde exvasado con labio marcado de sección redondeada. Torno lento. Cocción oxidante con postcocción o enfriamiento reductor. Pasta rosada-violácea. Desgrasantes heterométricos cuarcíticos. Diám. 110 mm. GRUPO D. ( $\left.\mathrm{n}^{\circ} 11132 / 11\right)$.

41. Fragmento de pared y borde de olla. Borde exvasado con labio de sección triangular. Torno lento. Cocción oxidante. Pasta parda oscura, la superficie exterior presenta zonas negruzcas que parecen fruto de una exposición de la pieza al fuego con posterioridad a la cocción. Desgrasantes de grano fino y medio micáceos, cuarcíticos, férricos y chamota. Decoración digital en el borde de la pieza. Diám. 110 mm. GRUPO D. (nº 11132/19).

42. Fragmento de pared y borde de olla. Borde exvasado de sección redondeada. Torno lento. Cocción oxidante con acabado reductor. Pasta crema. Desgrasantes heterométricos micáceos, cuarcíticos y vacuolas. Diám. 104 mm. GRUPO E. (nº 11132/6).

43. Fragmento de pared y borde de olla. Borde exvasado de sección redondeada. Torno lento. Cocción reductora con acabado oxidante. Pasta gris oscura en el centro, gris oscura y blanquecina en la superficie exterior, crema en la superficie interior. Desgrasantes heterométricos cuarcíticos y chamota. Diám. 120 mm. GRUPO E. (nº 11132/79).

\section{UE 4051}

\section{Terra sigillata}

1. T.S.H. Frag. de borde. Forma 8. P: M 37, con desgrasantes calizos y micáceos de grano fino. No conserva barniz. Borde oblicuo de labio apuntado ligeramente engrosado. Diám: 100 mm (n 10.927/2)

2. T.S.H. Frag. de borde. Forma 7. P: L 25 con desgrasantes calizos de granulometría muy fina. B: R 20. Borde oblicuo de sección apuntada. Diám: 140 mm. (n $\left.\mathrm{n}^{\mathrm{o}} 10.927 / 1\right)$

3. T.S.H.T. Tres frag. de borde. Forma 80-Palol 1. P: N 39 con desgrasantes calizos de grano fino. B: P 17 muy escaso. Borde de trayectoria vertical ligeramente invasado de labio ligeramente engrosado y pared con baquetón. Diám: 200 mm. ( ${ }^{\circ}$ 14.724).

4. T.S.H.T. Frag. de borde. Forma 37 t. P: N 37 con desgrasantes calizos de grano fino. No conserva barniz. Borde exvasado de labio redondeado. Diám: $170 \mathrm{~mm}\left(\mathrm{n}^{\mathrm{o}} 10.811 / 5\right)$.

5. T.S.H.T. Frag. de borde. Forma 8. P: M 37 con desgrasantes calizos de grano fino. No conserva 
barniz. Borde recto de sección apuntada, engrosado al exterior. Diám. 120 mm. (nº 10.811/1)

6. T.S.H.T. Frag. de borde. Forma 37 t. P: N 40 con desgrasantes calizos de grano fino. No conserva barniz. Borde exvasado de labio engrosado al exterior. Diám: 200 mm. ( $\mathrm{n}^{\circ}$ 10.811/4)

7. T.S.H.T. Frag. de pared. Forma indeterminada. P: N 39 con desgrasantes calizos de grano fino. No conserva barniz. Zig-zag estampillado. ( $\mathrm{n}^{\circ}$ 10.811/2)

8. T.S.H.T. Frag. de pared. Forma indeterminada. P: M 37 con desgrasantes calizos y micáceos de grano fino. No conserva barniz. Pared decorada con segmentos, círculos secantes y lúnulas. $\left(\mathrm{n}^{\circ} 10.811 / 7\right)$.

9. T.S.H.T. Frag. de pared. Forma indeterminada. P: M 37 con desgrasantes calizos y micáceos de grano fino. No conserva barniz. Pared decorada con ángulos enmarcados en círculos. ( $\left.\mathrm{n}^{\circ} 10.811 / 6\right)$.

\section{Imitación de T.S.G.G.T.}

10. Imitación T.S.G.G.T. Frag. de borde horizontal de labio redondeado. Cocción reductora, pastas grises con desgrasantes calizos y micáceos de grano fino y caliches cuarcíticos de grano medio y grueso. Superficies muy bien alisadas. Diám. $190 \mathrm{~mm}$. $\left(\mathrm{n}^{\circ}\right.$ 16.621/1).

11. Imitación T.S.G.G.T. Frag. de borde exvasado de labio redondeado perteneciente a posible cuenco. Cocción oxidante, pastas grises con desgrasantes calizos de grano fino. Diám: $90 \mathrm{~mm}$. (nº 16.621/2)

\section{Ánfora}

12. Siete frag. de cuello y asa pertenecientes a un ánfora tardía, posiblemente del tipo 1 de Keay. Torno, cocción reductora, pastas anaranjadas y pardas con abundantes desgrasantes calizos y cuarcíticos de grano medio. Superficie. ( $\left.\mathrm{n}^{\circ} 10.926\right)$.

\section{Cerámica Común Romana}

13. Frag. de borde exvasado de labio redondeado engrosado al exterior. Torno, cocción oxidante, pastas anaranjadas bien decantadas con desgrasantes calizos de grano fino, superficies alisadas. Diám. 50 mm. GRUPO 1. $\left(\mathrm{n}^{\circ} 10.813 / 1\right)$.

14. Frag. de borde exvasado de labio recto. Torno, cocción reductora de pastas negras con abundantes desgrasantes calizos y micáceos regularmente repartidos, superficies bien alisadas. Diám. $170 \mathrm{~mm}$. GRUPO 2. (nº 10.813/11).

15. Frag. de borde ligeramente exvasado y labio redondeado con ligera inflexión al exterior y pared recta. Torno, cocción reductora, pastas pardas y grises con abundantes desgrasantes calizos y cuarcíticos de grano medio regularmente repartidos, superficie ligeramente alisada. GRUPO 2. $\quad\left(\mathrm{n}^{\circ}\right.$ 10.813/13).

16. Dos fragmentos de borde exvasado con labio apuntado perteneciente a una olla. Torno, cocción mixta de pastas grises, pardas y anaranjadas con abundantes desgrasantes cuarcíticos de grano medio regularmente repartidos. Superficie alisada. Conserva restos de decoración incisa peinada. Diám. 160. Grupo 2. (nº 10.813/26).

17. Dos frag. de base plana. Torno, cocción mixta de pastas grises y anaranjadas con abundantes desgrasantes regularmente distribuidos calizos y micáceos de grano fino y medio y algún caliche cuarcítico. Superficie alisada. Diám. $110 \mathrm{~mm}$. GRUPO 2. ( $\left.\mathrm{n}^{\mathrm{o}} 10.813 / 5\right)$.

18. Frag. de pared. Torno, cocción mixta, pastas pardas $y$ ocres con abundantes desgrasantes regularmente repartidos, calizos, cuarcíticos y micáceos de grano fino y medio con superficie peinada en dos direcciones. GRUPO 2. ( $\left.\mathrm{n}^{\circ} 10.925 / 1\right)$.

19. Frag. de borde horizontal de sección triangular. Torno, cocción reductora, pastas grises y pardas con desgrasantes calizos de grano medio y micáceos de grano fino, superficies alisadas. GRUPO $3 \quad\left(\mathrm{n}^{\circ}\right.$ 10.925/2).

20. Frag. de borde exvasado de labio apuntado. Torno, cocción oxidante de pastas anaranjadas y rosadas $\mathrm{y}$ abundantes desgrasantes calizos $\mathrm{y}$ cuarcíticos de grano medio. Diám. $140 \mathrm{~mm}$ GRUPO 3. $\left(\mathrm{n}^{\mathrm{o}} 10.813 / 7\right)$.

21. Frag. de base plana. Torno, cocción mixta, pastas ocres, grises y amarillentas con desgrasantes calizos y cuarcíticos de grano medio. Diám. $110 \mathrm{~mm}$. GRUPO 3. ( $\left.\mathrm{n}^{\mathrm{o}} 10.813 / 8\right)$.

22. Frag. de base plana. Torno, cocción mixta irregular, de pastas grises y anaranjadas con abundantes desgrasantes calizos, cuarcíticos y micáceos de grano fino, medio y grueso. Diám. 70 mm. GRUPO 3. $\left(\mathrm{n}^{\circ} 10.813 / 6\right)$.

23. Tres frag. de borde perteneciente a un cuenco con borde oblicuo de labio redondeado engrosado al exterior. Torno, cocción oxidante de pastas ocres y pardas, desgrasantes calizos y micáceos de grano fino, superficie bien alisada. Conserva engobe rojo vinoso al interior. Diám: $160 \mathrm{~mm}$. GRUPO 4. $\left(\mathrm{n}^{\circ}\right.$ 10.819/4).

24. Dos frag. de borde perteneciente a un cuenco. Borde exvasado horizontal de sección recta. Torno, cocción mixta de pastas ocres y grises con desgrasantes calizos, micáceos y ferruginosos de grano fino, y calizos y cuarcíticos de grano medio, 
superficie alisada, conserva engobe al exterior. Diám: $270 \mathrm{~mm}$. GRUPO 4. (n $10.819 / 3)$.

25. Frag. de borde ligeramente exvasado de labio redondeado, perteneciente a una cazuela. Torno, cocción oxidante de pastas ocres y pardas con desgrasantes calizos y micáceos de grano fino, y calizos, cuarcíticos y ferruginosos de grano medio, superficie alisada. No conserva engobe. Diám: 300 mm. GRUPO 4. $\left(\mathrm{n}^{\circ} 10.819 / 5\right)$.

26. Cinco frag. de base plana perteneciente a un plato. Torno, cocción mixta con pastas anaranjadas, pardas y grises con abundantes desgrasantes de grano fino y medio calizos y micáceos y algún caliche cuarcítico, presenta engobe rojizo al interior $\mathrm{y}$ evidente acción de fuego al exterior. Diám: $120 \mathrm{~mm}$. GRUPO 4. ( $\left.\mathrm{n}^{\circ} 10.903\right)$.

27. Dos frag. de borde ligeramente oblicuo de labio recto y cuello perteneciente a botella. Torno, cocción reductora, pastas grises con desgrasantes calizos y cuarcíticos de grano fino y medio, superficies alisadas. Diám. 50 mm. GRUPO 5. (nº 10.813/2).

28. Frag. de base plana. Torno, cocción reductora con pastas grises con desgrasantes calizos y micáceos de grano fino y medio y superficie alisada. Diám. 30 mm. GRUPO 5. ( $\left.{ }^{\circ} 10.813 / 16\right)$.

29. Frag. de borde oblícuo apuntado perteneciente a un cuenco. Torno, cocción reductora, pastas grises y negras con abundantes desgrasantes calizos y cuarcíticos de grano medio, superficie alisada. Diám. $170 \mathrm{~mm}$. GRUPO 6. (n 10.813/9).

30. Cinco frag. de pared y borde oblicuo de labio recto con ligera inflexión al exterior. Torno, cocción oxidante, pastas rosadas con abundantes desgrasantes calizos y cuarcíticos de grano medio. Diám. $150 \mathrm{~mm}$. GRUPO 6. (nº 10.813/22).

31. Frag. de borde oblícuo de labio apuntado. Torno, cocción mixta, pastas pardas, grises y anaranjadas con desgrasantes de grano fino y medio calizos, cuarcíticos y micáceos. Superficie alisada. Diám. 190 mm. GRUPO 6. ( $\left.\mathrm{n}^{\mathrm{o}} 10.813 / 10\right)$. 33. Frag. de base plana. Torno, cocción oxidante de pastas anaranjadas con desgrasantes calizos, cuarcíticos y micáceos de grano fino y medio. Diám. $74 \mathrm{~mm}$. GRUPO 6. $\left(\mathrm{n}^{\circ}\right.$ 10.813/17).

32. Frag. de borde ligeramente exvasado de labio redondeado. Torno, cocción oxidante de pastas anaranjadas y ocres con desgrasantes calizos y micáceos de grano fino, y cuarcíticos y ferruginosos de grano medio. GRUPO 6. (nº 10.813/14).

33. Frag. de base plana. Torno, cocción oxidante de pastas anaranjadas con desgrasantes calizos, cuarcíticos y micáceos de grano fino y medio. Diám. $74 \mathrm{~mm}$. GRUPO 6. (n 10.813/17).

34. Frag. de base plana. Torno lento, cocción oxidante de pastas pardas, anaranjadas y amarillentas con abundantes desgrasantes calizos, cuarcíticos, ferruginosos y latericio de grano medio, superficie ligeramente alisada. Diám. $104 \mathrm{~mm}$. GRUPO 6. $\left(\mathrm{n}^{\circ}\right.$ 10.813/21).

\section{Vidrio}

35. Frag, de borde de un plato. Vidrio incoloro traslúcido. Diám. $250 \mathrm{~mm}$. El borde es ligeramente viselado, Forma Isings 116 b. ( $\left.\mathrm{n}^{\circ} 12507\right)$

\section{Metal}

36. Podadera. Hierro. Pieza formada por una hoja de cuchilla de forma curva. Terminado, en la parte superior, en punta, y, en la parte inferior en un corte transversal rematado con dos remaches de hierro para fijar la pieza al mango. ( $\mathrm{n}^{\circ}$ 14712)

37. Gancho. Hierro. Vástago de sección rectangular, uno de sus extremos se encuentra curvado formando una anilla, el otro termina en punta, se encuentra doblado y fracturado. Presenta una fractura en uno de sus extremos. $\left(\mathrm{n}^{\circ}\right.$ 14717)

38. Aro. Posible eslabón de sección irregular. Hierro. $\left(\mathrm{n}^{\circ} 14718\right)$

39. Cuchillo. Hierro. Frag. de hoja larga y estrecha de cuchillo con la punta partida. Lomo recto y arranque de mango fracturado. ( $\left.\mathrm{n}^{\circ} 14702\right)$

40. Cuchillo. Hierro. Fragmento de hoja larga y estrecha de cuchillo con la punta fracturada. Lomo recto y mango de forma y sección rectangular plana.. $\left(\mathrm{n}^{\mathrm{o}} 14707\right)$

41. Frag. de sítula y argolla para el soporte del asa. Bronce. Presenta un aplique figurativo en bronce sujeto a la pared mediante tres remaches en bronce. El motivo decorativo es un rostro humano de forma oval. En su extremo superior presenta un ojal circular que permite el enganche del asa. $\left(n^{\circ} 14722\right)$

42. Pico. Hierro. Pequeña piqueta sin orificio central. Presenta un doble filo a ambos extremos, uno de sección rectangular con corte horizontal, y otro de menor tamaño, sección rectangular con corte vertical. $\left(\mathrm{n}^{\circ} 14719\right)$

43. Aguja. Bronce. Vástago de sección circular muy fino fracturado en sus extremos. $\left(n^{\circ} 14727\right)$

\section{Cerámica de época medieval.}

44. Frag. de borde de olla. Borde exvasado de sección redondeada. Realizado a torno lento. Cocción reductora. Pasta gris-azulada oscura. Desgrasantes 
heterométricos de caliza, cuarcita y vacuola. Diám. 100 mm. GRUPO C. (nº 10924/3).

45. Dos frag. de pared. Realizado a torno lento. Cocción oxidante. Pasta naranja. Desgrasantes heterométricos de cuarcita, caliza, mica, vacuola y chamota. Decoración de onda doble incisa. GRUPO D. $\left(n^{\circ} 10924 / 4\right)$.

46. Fragmento de pared y base, con pie. Realizado a torno lento. Cocción oxidante con postcocción o enfriamiento reductor. Pasta naranja clara en el centro y en la superficie interior, en la superficie exterior adquiere un tono negruzco. Desgrasantes heterométricos cuarcíticos, micáceos, férricos y chamota. Presenta marca de unión entre la base y la pared de la pieza. Diám. $100 \mathrm{~mm}$. GRUPO D. $\left(\mathrm{n}^{\circ}\right.$ 10924/5).

\section{UE 4165}

\section{Terra Sigillata}

1. T.S.H. Frag. de borde. Forma 15/17. P: L 25 con desgrasantes calizos de grano muy fino. B: P 11. Descripción: borde oblicuo de labio redondeado, ligeramente engrosado al exterior. $\left(\mathrm{n}^{\mathrm{o}}\right.$ 16.522/1)

2. T.S.H.T. Frag. de borde. Forma 6/Palol 8b, P: M 35 con desgrasantes calizos de grano fino. B: sólo conserva algo en el labio. Descripción: borde horizontal decorado con roseta y motivo en zig-zag, Diám. 140 mm. (n 16.521/1).

3. T.S.H.T. Ocho frag. de borde. Forma H 37. P: M 37 con desgrasantes calizos de grano fino, B: conserva muy escasos retazos. Descripción: borde oblicuo engrosado al exterior y panza decorada con círculos secantes segmentados. Diám. $180 \mathrm{~mm}$. $\left(\mathrm{n}^{\circ}\right.$ $16.521 / 2)$.

4. T.S.H.T. seis frag. de borde. Forma 74/ Palol 4. P: M 39 con desgrasantes calizos de grano muy fino. B: no conserva. Descripción: borde horizontal engrosado en su remate final. Diám. $180 \mathrm{~mm}$. $\left(\mathrm{n}^{\circ}\right.$ $16.521 / 3)$.

5. T.S.H.T. Frag. de borde. Forma 80/Palol 1. P: M 39 con desgrasantes calizos y micáceos de grano fino. B: no conserva. Descripción: borde oblicuo de sección triangular con pestaña para tapadera. $\left(\mathrm{n}^{\circ}\right.$ 16.521/4).

6. T.S.H.T. Frag. de borde. Forma 77/Palol 4. P: M 39 con desgrasantes calizos y micáceos de grano fino. B: no conserva. Descripción: borde horizontal de labio redondeado, ligeramente engrosada al exterior. Diám. 200 mm. (n 16.521/5).

7. T.S.H.T. Frag. de borde. Forma H 37. P: M 35 con desgrasantes calizos y micáceos de grano fino. B: no conserva. Descripción: borde recto de labio engrosado al exterior. Diám.: 220 mm. (nº 16.521/8).

8. T.S.H.T. Tres frag. de borde. Forma H 37. P: M 39 con desgrasantes calizos y micáceos de grano fino $\mathrm{B}$ : no conserva. Descripción: borde oblicuo de sección redondeada. Diám.: 240 mm. (nº 16.521/6).

9. T.S.H.T. Veintitrés frag. de perfil completo. Forma: 77/Palol 5/Paz Peralta 82. P: N 40 muy decantadas con desgrasantes calizos y micáceos de grano fino. B: R 20 conserva escasos retazos. Descripción: plato carenado de base plana y borde recto de labio apuntado ligeramente engrosado al exterior. Diám. 290 mm. (n 16.529).

10. T.S.H.T. Frag. de base. Forma indeterminada. P: M 39 con desgrasantes calizos y micáceos de grano fino. B: no conserva. Descripción: base anular decorada al interior con bastoncillos segmentados describiendo un motivo estrellado. Diám: $64 \mathrm{~mm}\left(\mathrm{n}^{\circ}\right.$ 16.521/7).

11. T.S.H.T. Veinticinco frag. de pared. Forma indeterminada. P: M 37 con desgrasantes calizos y micáceos de grano fino. B: no conserva. Descripción: pared decorada con líneas oblicuas en dos direcciones, en "motivos de cestería". (n 16.521/9).

\section{Cerámica común romana}

12. Dos frag. de base plana y pared oblicua. Torno, cocción oxidante, pastas bien decantadas con desgrasantes calizos y micáceos de grano fino, superficies alisadas. Diám. $50 \mathrm{~mm}$. GRUPO 1. $\left(\mathrm{n}^{\circ}\right.$ 16.520/8).

13. Frag. de borde exvasado con labio redondeado de olla. Torno, cocción irregular de pastas ocres y grises con abundantes desgrasantes calizos, cuarcíticos y micáceos de grano fino y medio, superficie alisada. Diám. 100 mm. GRUPO 2. (nº 16.520/1).

14. Frag. de borde exvasado de labio apuntado. Torno, cocción mixta de pastas grises y pardas con abundantes desgrasantes regularmente distribuidos, calizos, cuarcíticos y micáceos de grano fino y medio, superficie alisada. Diám. 140 mm. GRUPO 2. $\left(n^{\circ} 16.520 / 4\right)$.

15. Dos frag. de pared. Torno, cocción mixta de pastas anaranjadas, pardas y gris oscuro con abundantes desgrasantes calizos, cuarcíticos y micáceos de grano fino y medio. Superficie peinada. GRUPO 2 ( $\left.\mathrm{n}^{\circ} 16.526 / 2\right)$.

16. Doce frag de pared. Torno, cocción mixta con pastas pardas, grises y anaranjadas con abundantes desgrasantes calizos, cuarcíticos y micáceos de grano fino y medio; superficie peinada. GRUPO 2. $\left(\mathrm{n}^{\circ}\right.$ $16.526 / 3)$. 
17. Frag. de borde horizontal de sección triangular perteneciente a una olla. Torno, cocción mixta, pastas pardas, anaranjadas y grises con abundantes desgrasantes calizos, cuarcíticos y micáceos de grano fino y medio, decoración a peine de líneas concéntricas en el labio. Diám. 140 mm. GRUPO 2. (n $\left.n^{\circ} 16.526 / 1\right)$.

18. Frag. de base plana de plato. Torno, cocción mixta irregular de pastas ocres, pardas y anaranjadas con abundantes desgrasantes calizos, cuarcíticos y micáceos de grano fino y medio regularmente distribuidos. Diám. $106 \mathrm{~mm}$. GRUPO 2. (n 16.520/7).

19. Frag. de borde exvasado de labio apuntado. Torno, cocción oxidante con pastas anaranjadas y abundantes desgrasantes calizos, cuarcíticos y micáceos de grano fino, medio y grueso, superficie alisada. Diám. 180 mm. GRUPO 3. (n 16.520/9).

20. Frag. de borde exvasado de labio redondeado. Torno, cocción mixta de pastas anaranjadas y grisáceas con abundantes desgrasantes calizos, cuarcíticos y micáceos de grano fino y medio. GRUPO 3. (n⿳⺈ 16.520/5).

21. Tres frag. de perfil completo de plato con borde oblicuo de labio ligeramente biselado con doble acanaladura, pared oblicua y base recta. Torno, cocción oxidante de pastas anaranjadas con desgrasantes calizos, cuarcíticos y micáceos de grano fino y medio, superficie bien alisada. Engobe rojo vinoso al interior. Diám. $160 \mathrm{~mm}$. GRUPO 4. (nº 16. 527/1).

22. Dos frag. de borde ligeramente exvasado y labio redondeado engrosado al exterior. Torno, cocción reductora, pastas grises con desgrasantes calizos y micáceos de grano fino y medio, superficie bien alisada; seguramente misma pieza que número 16.528. Diám. 60 mm. GRUPO 5 (nº 16.520/2).

23. Base plana y once frag. de pared. Torno, cocción reductora de pastas grises y ocres con desgrasantes calizos y micáceos de grano fino y medio y alguno cuarcítico de mayor calibre. Superficies bien alisadas, algunos fragmentos de pared con incisión, seguramente misma pieza que 16.520/2 y 3. Diám. 40 mm. GRUPO 5 ( $\left.\mathrm{n}^{\circ} 16.528\right)$.

24. Dos frag. de asa de sección rectangular. Torno, cocción reductora, de pastas pardas y grises con desgrasantes calizos y micáceos de grano fino y medio. Superficie alisada. Posiblemente misma pieza que 16.520/2 y 16.528. GRUPO 5. (n⿳ 16.520/3).

25. Dos frag. de pie de copa. Torno, cocción reductora, pastas ocres y grises con desgrasantes calizos, cuarcíticos y micáceos de grano fino $\mathrm{y}$ medio, superficie alisada. GRUPO 5. (nº 16.520/6).

26. Frag. de base plana y pared oblicua. Torno, cocción mixta con pastas ocres y grises y abundantes desgrasantes calizos, cuarcíticos y micáceos de grano medio y grueso. Superficie simplemente alisada. Diám. 74 mm. GRUPO 6. (n 16.520/11).

\section{Vidrio}

27. Frag, de borde y asa de una jarra. . Vidrio verde amarillento. Asa replegada de cinta. Forma Isings 121 b. (n' 14. 833).

28. Frag. de pié de una copa o jarra. Vidrio verde tralúcido. Diám.470 mm. Forma Isings 111. ( $\mathrm{n}^{\circ}$ 14.836)

\section{Metal}

29. Pulsera. Bronce. Pulsera incompleta compuesta por una lámina de bronce lisa y con sección rectangular, cuyo cierre se realiza superponiendo los extremos de la lámina y remachándolos. Presenta una decoración incisa formada por dos series de ondas paralelas. Estado de conservación: Malo. Se encuentra incompleta y sus bordes presentan una fractura irregular. Presenta una superficie rugosa y exfoliada que apenas permite distinguir la decoración. (nº 14843)

30. Anillo. Bronce. Aro de bronce liso y sección rectangular. En su parte superior presenta un ligero ensanchamiento en el que destaca una decoración incisa enmarcada en un rectángulo totalmente perdida. Estado de conservación: Malo. Presenta una superficie rugosa y exfoliada. Sus bordes presentan una fractura irregular. ( $\left.\mathrm{n}^{\circ} 14820\right)$

31. Puñal tipo Simancas. Hierro y bronce. Conjunto de puñal, empuñadura, y vaina. Presenta una hoja incompleta de dorso recto en hierro, conservándose únicamente un fragmento de la base, enmangado mediante un remache de bronce a una empuñadura de bronce torneado. La vaina presenta las cantoneras de bronce prácticamente completas, mientras la funda de lámina de bronce carece de decoración y presenta un orificio de grandes proporciones. Estado de conservación: Tanto la vaina como el enmangue se encuentran en buen estado, siendo la pieza peor conservada la hoja en hierro, fracturada y exfoliada. $\left(n^{\circ} 14837, n^{\circ} 14838\right)$

32. Amella. Bronce. Pequeña lámina plegada formando un arito cilíndrico, con los extremos paralelos atravesados por una perforación para su sujeción. Estado de conservación: Bueno. (n 14828)

33. Tachón. Hierro. Clavo ornamental con gran cabeza circular, en forma de casquete esférico, 
deformada y corto espigo de sección cuadrangular. Estado de conservación: Bueno, se conserva completo aunque con la superficie exfoliada. $\left(\mathrm{n}^{\mathrm{o}}\right.$ 14815)

34. Hebilla. Hierro. Aro de sección circular que conserva la mitad de la aguja, de sección plana, soldada a la hebilla por la zona en la que la punta reposa sobre ésta. Estado de conservación: Regular, superficie rugosa y exfoliada. $\left(\mathrm{n}^{\circ} 14827\right)$

35.Abrazadera. Hierro. Objeto realizado en placa rectangular curvada para formar un cilindro abierto con los bordes vueltos horizontalmente. Sección plano-convexa. Estado de conservación: Bueno. $\left(\mathrm{n}^{\circ}\right.$ 14832)

36. Hembrilla. Hierro. Objeto formado por un astil de sección circular rematado por una cabeza circular plano-convexa, en un extremo, y por una anilla en el otro. Estado de conservación: Bueno se conserva completo. $\left(n^{\circ} 14841\right)$

\section{UE 4166}

\section{Terra Sigillata}

1. T.S.H.T Frag. de borde. Forma 6/ Palol 8c. P: N 37 con desgrasantes calizos de grano fino. B: R 20, conserva escasos retazos. Descripción: borde horizontal de labio redondeado y ligeramente engrosado. Diám.: 140 mm. ( $\left.{ }^{\circ} 16.432 / 2\right)$.

2. T.S.H.T. Frag. de borde. Forma H 37t. P: M 37 con escasos desgrasantes micáceos de grano fino. B: prácticamente no conserva. Descripción: borde de trayectoria oblicua con labio de sección alargada levemente engrosado al exterior. Diám. $520 \mathrm{~mm}$. $\left(\mathrm{n}^{\circ}\right.$ $16.532 / 1)$.

\section{Cerámica de paredes finas}

3. Frag. de borde exvasado perteneciente a un cuenco. Torno, cocción oxidante con pastas anaranjadas muy depuradas con desgrasantes de grano muy fino y superficie alisada. $\left(\mathrm{n}^{\mathrm{o}} 16.535 / 1\right)$.

\section{Cerámica Común Romana}

4. Frag. de borde horizontal de sección triangular. Torno, cocción mixta de pastas rojizas y grisáceas bien decantadas con desgrasantes calizos y micáceos de grano fino y superficie bien alisada. Diám.: 100 mm GRUPO 1. (nº 16.531/5).

5. Frag. de base plana y pared. Torno, cocción oxidante, pastas anaranjadas con desgrasantes micáceos y calizos de grano fino y medio, superficies alisadas. Diám.: 110 mm. GRUPO 1. (nº 16.531/7).
6. Frag. de base plana. Torno, cocción oxidante, pastas anaranjadas con desgrasantes finos calizos, superficies bien alisadas. Diám.: 90 mm. GRUPO 1 . $\left(n^{\circ} 16.532 / 6\right)$.

7. Frag. de base plana. Torno cocción oxidante pasta naranja con desgrasantes calizos de grano fino y medio, superficies alisadas. Diám.: $80 \mathrm{~mm}$ GRUPO 1. $\left(\mathrm{n}^{\mathrm{o}} 16.531 / 8\right)$.

8. Dos frag. de asa de cinta. Cocción oxidante, pastas anaranjadas con abundantes desgrasantes calizos y micáceos de grano fino y medio, superficies alisadas. GRUPO 1. (n $16.531 / 9)$.

9. Frag. de borde exvasado de labio recto y pared de olla. Torno, cocción reductora con abundantes desgrasantes calizos y cuarcíticos y algún micáceo de grano fino y algún esporádico de grano grueso, superficie alisada con tres líneas incisas en el arranque de la panza. Diám. $120 \mathrm{~mm}$. GRUPO 2. $\left(\mathrm{n}^{\circ}\right.$ 16.531/1).

10. Frag. de borde exvasado de sección redondeada. Torno, cocción reductora irregular con abundantes desgrasantes cuarcíticos y micáceos de grano fino, acabado alisado. Diám. $140 \mathrm{~mm}$. GRUPO 2. $\left(\mathrm{n}^{\circ}\right.$ 16.531/2).

11. Sesenta y nueve fragmentos de borde y panza de olla, borde exvasado de sección redondeada y panza ovoide. Torno, cocción oxidante, pasta anaranjada con abundantes desgrasantes calizos y cuarcíticos de grano fino y medio, superficie alisada. Restos de acción de fuego. Diám. $160 \mathrm{~mm}$. GRUPO 2. $\left(\mathrm{n}^{\circ}\right.$ 16.537).

12. Cincuenta y ocho fragmentos de borde y panza pertenecientes a una olla de borde exvasado de sección redondeada. Torno, cocción mixta irregular, pasta gris y anaranjada con desgrasantes de grano medio calizos y cuarcíticos, superficie peinada. Diám. 140 mm. GRUPO 2. (nº 16.538).

13. Cinco frag. de borde exvasado de sección apuntada y panza. Torno, cocción mixta, pastas grises y anaranjadas con abundantes desgrasantes finos y medios cuarcíticos y alguno micáceos. Diám. 100 mm. GRUPO 2. ( $\left.\mathrm{n}^{\circ} 16.531 / 3\right)$.

14. Frag. de base plana. Torno, cocción reductora con abundantes desgrasantes finos y medios cuarcíticos y calizos, superficie alisada. Diám. $100 \mathrm{~mm}$. GRUPO 2 $\left(\mathrm{n}^{\mathrm{o}} 16.531 / 4\right)$.

15. Frag. de base plana. Torno, cocción reductora, pastas grises con abundantes desgrasantes calizos, cuarcíticos y micáceos de grano medio y grueso, superficie alisada. Diám. $70 \mathrm{~mm}$. GRUPO 3. $\left(\mathrm{n}^{\circ}\right.$ 16.531/11). 
16. Frag. de borde horizontal con acanaladura y sección cuadrangular perteneciente a un cuenco de pared oblicua. Torno, cocción oxidante, pastas bien decantadas de color pardo y gris negruzco por acción del fuego, abundantes desgrasantes micáceos de grano fino, superficie alisada, conserva engobe rojo vinoso en acanaladura borde. Diám. $180 \mathrm{~mm}$. GRUPO 4. (n 16.534/1).

17. Plato de perfil completo de borde oblicuo y sección redondeada, ligeramente engrosada al exterior, base plana con grafito en aspa enmarcado en círculo, pared de curva convexa. Torno, cocción oxidante y pastas ocre-anaranjadas bien decantadas con desgrasantes finos micáceos y algún caliche de calibre grueso cuarcíticos y calizos. Superficies alisadas. Presenta engobe anaranjado rojizo al interior y en el labio. Se observa acción del fuego en todo el exterior de la pieza. Diám.: $160 \mathrm{~mm}$. GRUPO 4. $\left(\mathrm{n}^{\circ}\right.$ $16.536 / 1)$.

18. Frag. de borde exvasado de sección redondeada perteneciente a una olla/jarra. Torno, cocción reductora, pastas pardas y grises con desgrasantes finos calizos y micáceos. Superficie alisada. Diám. $110 \mathrm{~mm}$. GRUPO 5. ( $\left.\mathrm{n}^{\circ} 16.531 / 10\right)$.

19. Frag. de base plana con el pie remarcado. Torno, cocción oxidante con pastas anaranjadas con abundantes desgrasantes cuarcíticos, calizos, micáceos y de latericio, medios y gruesos. Superficie ligeramente alisada. Diám. $60 \mathrm{~mm}$. GRUPO 6. $\left(\mathrm{n}^{\circ}\right.$ 16.531/13).

20. Dos frag. de base plana. Torno, cocción oxidante con pastas anaranjadas con abundantes desgrasantes cuarcíticas, micáceos y de latericio medios y gruesos. Superficie alisada. Diám. $70 \mathrm{~mm}$. GRUPO 6. $\left(\mathrm{n}^{\circ}\right.$ 16.531/12).

\section{Metal}

21. Placa. Hierro. Fragmento rectangular de sección plana; un extremo recto y el otro redondeado; cerca de éste último presenta parte de un clavo. Estado de conservación: Regular, superficie rugosa y exfoliada. $\left(\mathrm{n}^{\circ} 14856\right)$

22. Pomo. Hierro. Conjunto formado por una lámina trapezoidal con perforación central, en la que se inserta un pomo con espigo de sección circular, con extremo aplanado y cabeza engrosada. Estado de conservación: Regular, presenta una superficie rugosa y la cabeza informe. ( $\left.\mathrm{n}^{\circ} 14863\right)$

23. Anilla. Hierro. Varilla de sección cuadrangular curvada en forma circular sin que los extremos lleguen a tocarse, dejando una pequeña abertura. Estado de conservación: Malo, se encuentra incompleta y con la superficie exfoliada. $\left(\mathrm{n}^{\circ} 14864\right)$
25.Cencerro. Latón. Cencerro en latón de forma trapezoidal. Estado de conservación: Malo, se encuentra fragmentado faltando parte de su mitad inferior. No conserva el badajo, y ha perdido el aro de sujeción superior. ( $\left.\mathrm{n}^{\mathrm{o}} 14858\right)$

26. Cencerro. Latón. Cencerro en latón de forma trapezoidal. Estado de conservación: Regular, no se conserva completo presentando varios orificios. No conserva el badajo, y el aro de sujeción superior se encuentra incompleto. La superficie es rugosa y fuertemente exfoliada. $\left(\mathrm{n}^{\circ}\right.$ 14857)

\section{Azabache}

24. Cuenta de collar realizada en azabache, de sección circular achatada en extremos distal y proximal, de $15 \mathrm{~mm}$ de diámetro, presenta perforación central longitudinal para enfilar la cuenta. Decoración incisa de líneas paralelas agrupadas en secciones triangulares y de sentido alterno.

\section{UE 4169}

\section{Terra Sigillata}

1. T.S.H. Frag. de borde. Forma 4. P: N 71 con desgrasantes calizos muy finos, pasada de cocción. B: no conserva. Descripción: borde exvasado de labio recto con acanaladura. $\left(\mathrm{n}^{\circ} 16.567 / 1\right)$.

2. T.S.H.T. Frag. de borde. Forma: H 37t. P: M 37 con desgrasantes calizos de calibre fino. B: no conserva. Descripción: borde oblicuo engrosado al exterior. ( $\left.\mathrm{n}^{\mathrm{o}} 16.566 / 1\right)$.

3. T.S.H.T. Frag. de borde. H 37 P: M 39 con desgrasantes calizos de grano fino. B: no conserva. Descripción: borde oblicuo engrosado al exterior. Diám. 240 mm. (n 16.566/2).

4. T.S.H.T. Frag. de pared. P: M 25 con desgrasantes calizos y micáceos de grano fino. B: no conserva. Descripción: pared decorada a molde con semicírculos secantes, puntas de flecha y flores, muy erosionado.( $\left.\mathrm{n}^{\circ} 16.566 / 3\right)$.

\section{Cerámica Común Romana}

5. Frag. de borde recto ligeramente exvasado de sección redondeada. Torno, cocción oxidante con pastas depuradas anaranjadas con desgrasantes de grano fino y superficie alisada. Diám. $32 \mathrm{~mm}$ GRUPO 1. ( $\left.n^{\circ} 16.565 / 1\right)$.

6. Frag. de borde oblicuo, labio redondeado ligeramente biselado al interior, perteneciente a un cuenco. Torno, cocción oxidante, pastas rojizas bien decantadas y superficie alisada. Diám. $170 \mathrm{~mm}$. GRUPO 1. (n $\left.\mathrm{n}^{\circ} 16.565 / 2\right)$. 
7. Frag. de borde oblicuo de labio redondeado. Torno, cocción mixta de pastas anaranjadas con nervio gris, abundantes desgrasantes calizos y cuarcíticos de grano fino y medio uniformemente distribuidos. GRUPO 2. (n $\left.n^{\circ} 16.565 / 9\right)$.

8. Frag. de base plana. Torno, cocción reductora, pastas grises con abundantes desgrasantes de grano fino. Superficie alisada. GRUPO 2. $\left(\mathrm{n}^{\circ}\right.$ 16.568/2).

9. Frag. de borde horizontal de sección triangular perteneciente a una olla, el labio presenta decoración a peine con líneas concéntricas. Torno, cocción mixta con pastas pardas y grises con abundantes desgrasantes calizos de grano fino y medio. Diám. $250 \mathrm{~mm}$. GRUPO 2. ( $\left.\mathrm{n}^{\mathrm{o}} 16.568 / 1\right)$.

10. Dos frag. de borde de jarra con pico vertedor. Torno, cocción mixta, pastas pardas con abundantes desgrasantes calizos y cuarcíticos de grano fino y medio uniformemente distribuidos. GRUPO 2. $\left(\mathrm{n}^{\circ}\right.$ $16.565 / 10)$.

11. Cinco frag. de olla de borde exvasado y pared ovoide decorada con incisiones verticales. Torno, cocción mixta de pastas pardas y grises con abundantes desgrasantes calizos y cuarcíticos que afloran a la superficie. Diám. $130 \mathrm{~mm}$ GRUPO 3. $\left(\mathrm{n}^{\circ}\right.$ $16.565 / 3)$.

12. Frag. de borde horizontal de olla con decoración a peine en líneas concéntricas e incisión en $\mathrm{V}$ en el labio. Torno lento, cocción reductora con pastas grises con abundantes desgrasantes calizos y cuarcíticos de grano medio y grueso. Superficie alisada. GRUPO 3. (n 16.565/4).

13. Frag. de pared y arranque de asa de cinta decorada con líneas incisas paralelas. Torno, cocción mixta con pastas pardas, ocres y grises con abundantes desgrasantes calizos y cuarcíticos que afloran a la superficie. GRUPO 3. ( $\left.\mathrm{n}^{\mathrm{o}} 16.565 / 8\right)$.

14. Frag. de base plana. Torno, cocción mixta, pastas pardas y anaranjadas con abundantes desgrasantes calizos y cuarcíticos de grano medio y grueso que afloran a la superficie. Acabado alisado. Diám. 120 mm. GRUPO 3. $\left(n^{\circ} 16.565 / 6\right)$.

15. Dieciséis frag. de borde horizontal de labio redondeado, cuerpo troncocónico ligeramente convexo y base plana de un cuenco barreño o lebrillo. Torno, cocción oxidante de pastas anaranjadas rosáceas con abundantes desgrasantes que finos y muy grusesos, calizos, cuarcíticos, micáceos, férricos y caliches de latericio. Superficies alisadas. Diám. $180 \mathrm{~mm}$. GRUPO 6. $\left(\mathrm{n}^{\circ}\right.$ 16.576)

Vidrio
16. Frag. de pié de una copa. Vidrio verde traslúcido. Diám. 60 mm. Forma Isings 111. (nº 14786)

\section{Hueso}

17. Acus crinalis, alfiler para el cabello realizado en hueso, de $45 \mathrm{~mm}$ de longitud y sección circular de 5 $\mathrm{mm}$ de diámetro ligeramente engrosado en la zona central del vástago, presenta fracturas en sus dos extremos. Decoración incisa de bandas horizonales reticuladas. $\left(\mathrm{n}^{\circ} 14.770\right)$

\section{UE 4170}

\section{Terra sigillata}

1. T.S.H.T. Cuatro fragmentos de borde y pared. Forma 37 t atípica. P: N 45 con desgrasantes calizos y micáceos de grano fino. B: P 35 mal conservado. Descripción: borde oblícuo de labio redondeado ligeramente estrechado decorado con círculos concéntricos (tercer estilo). Diám: $190 \mathrm{~mm}$. $\left(\mathrm{n}^{\circ}\right.$ $16.501 / 2)$

\section{Cerámica común romana}

2. Dos fragmentos de base plana y pared. Torno, cocción oxidante con abundantes desgrasantes calizos cuarcíticos y micáceos de grano fino y medio. Superficie alisada. Diám: $54 \mathrm{~mm}$. GRUPO 2. $\left(\mathrm{n}^{\circ}\right.$ 16.502/3)

3. Seis fragmentos de base plana y pared con arranque de asa perteneciente a una jarra. Torno, cocción mixta de pastas anaranjadas y grisáceas con desgrasantes calizos cuarcíticos y férricos de grano fino y medio. Superficie muy alisada. Diám: $76 \mathrm{~mm}$. GRUPO $1\left(n^{\circ} 16.502 / 1\right)$

4. Catorce fragmentos de base plana y pared con decoración incisa a peine, cocción irregular con pastas grises y anaranjadas con abundantes desgrasantes calizos y cuarcíticos de grano medio uniformemente repartidos. GRUPO 2. ( $\mathrm{n}^{\circ}$ 16.505)

5. Fragmento de borde recto de labio redondeado ligeramente engrosado al interior y cuello con carena marcada, perteneciente a una jarra. Torno, cocción oxidante de pastas anaranjadas con abundantes desgrasantes cuarcíticos, calizos y férricos de grano medio y grueso y micáceos de grano fino. Superficie alisada. Diám: 90 mm. GRUPO 3 (nº 16.502/2)

\section{Vidrio}

6. Frag. de borde de un vaso. Vidrio verde amarillento pulido al fuego. Diám. $140 \mathrm{~mm}$. El labio está engrosado y la pared es recta o ligeramente cóncava. Forma Isings 106 a. (14.809).

7. Frag. de borde de un plato. Vidrio incoloro traslúcido. Diám. $180 \mathrm{~mm}$. El borde es ligeramente 
invasado y pertenece al grupo conocido como de "cabeza de fósforo". Forma Isings 116 b. (n 14.804)

\section{Metal}

8. Bisagra. Hierro. Pieza de bisagra en forma de placa rectangular con dos perforaciones, para su sujeción mediante clavado, y pasador acodado de sección circular, formando ángulo recto en uno de los extremos de la placa, que serviría de eje de revolución a la bisagra. Estado de conservación: Bueno. ( $n^{\circ}$ 14802)

9. Bisagra. Hierro. Pieza de bisagra en forma de placa triangular con una perforación, cercana a la base de la placa, para su sujeción mediante clavado y una charnela cilíndrica en el vértice. Estado de conservación: Bueno. (nº 14807)

10. Colgador. Hierro. Objeto realizado en varilla de sección rectangular con la zona central aplanada y ensanchada, formando una placa ovalada con perforación central; un extremo aparece curvado en sentido perpendicular a la placa y el otro en paralelo. Estado de conservación: Regular, se conserva incompleto con los extremos fracturados. $\left(\mathrm{n}^{\circ} 14808\right)$

\section{UE 4401}

\section{Terra Sigillata Hispánica}

1. T.S.H.T Frag. de pared. Forma indeterminada. P:N 25 con desgrasantes calizos y micáceos de grano fino. B: no conserva. Descripción: restos muy deteriorados de decoración a molde de semicírculo secante y línea en zig-zag. (16.541/1).

\section{Imitación de T.S.G.G.T.}

2. Dos frag. de pared y arranque de borde con estampilla en serie de roseta. Cocción reductora de pastas bien depuradas de color pardo y superficies grises con desgrasantes micáceos y calizos de grano fino, superficie alisada. $\left(\mathrm{n}^{\circ}\right.$ 16.542).

\section{Cerámica Común Romana}

3. Frag de borde exvasado de sección redondeada. Torno, cocción mixta, pastas anaranjadas y grisáceas con abundantes desgrasantes calizos y micáceos de grano fino y alguno medio. Superficie alisada. Diám.: 90 mm GRUPO 1. (n $16.540 / 2)$.

4. Frag. de borde horizontal de sección triangular perteneciente a una olla con decoración incisa vertical en la pared y concéntrica en el borde. Torno lento, cocción mixta, pastas pardas y negras con desgrasantes calizos de grano medio y grueso. Diám. $110 \mathrm{~mm}$. GRUPO 3. (n⿳⺈⿴囗十一 16.544/1).

5. Frag. de base plana. Torno, cocción mixta de pastas pardas y negruzcas con abundantes desgrasantes calizos, cuarcíticos y micáceos de grano medio y grueso. Diám.: $90 \mathrm{~mm}$. GRUPO 3. $\left(\mathrm{n}^{\circ}\right.$ $16.540 / 7)$.

6. Tres frag. de base plana. Torno, cocción mixta irregular con pastas pardas, anaranjadas y grisáceas con abundantes desgrasantes calizos, cuarcíticos y micáceos de grano medio y grueso. Diám.: $106 \mathrm{~mm}$. GRUPO 2. ( $\left.\mathrm{n}^{\circ} 16.540 / 3\right)$.

7. Dos frag. de borde exvasado de sección redondeada y pared oblicua de cuenco. Torno, cocción reductora, pastas grises al interior y ocres al exterior con abundantes desgrasantes micáceos de grano fino y más escasos cuarcíticos y calizos de grano medio y grueso, superficie bien alisada, conserva algo de engobe rojo vinoso al interior. Evidente exposición al fuego. Diám. $290 \mathrm{~mm}$. GRUPO 4 (nº 16.543/1).

8. Dos frag. de borde oblicuo de sección redondeada ligeramente engrosado perteneciente a un cuenco. Torno, cocción oxidante, pastas ocres con desgrasantes calizos y micáceos de grano fino, superficie alisada. Conserva engobe rojo vinoso en labio y al interior. Restos de acción del fuego. Diám. 240 mm. GRUPO 4 (n 16.545/1). )

9. Frag. de borde horizontal con labio redondeado decorado con incisión en zig-zag. Torno, cocción mixta irregular de pastas anaranjadas y grisáceas con abundantes desgrasantes cuarcíticos y micáceos de grano fino y medio, superficies alisadas. Diám.: 140 mm. GRUPO 6. ( $\left.n^{\circ} 16.540 / 1\right)$.

10. Frag. de base plana. Torno, cocción oxidante, pastas anaranjadas con abundantes desgrasantes de grano medio calizos y cuarcíticos y finos micáceos. Superficie ligeramente alisada. Diám $104 \mathrm{~mm}$. GRUPO 6. $\left(\mathrm{n}^{\circ} 16.540 / 5\right)$.

11. Frag. de borde exvasado de sección redondeada perteneciente a una olla. Torno, cocción reductora de pastas duras grisáceas con desgrasantes calizos de grano fino y medio con afloramiento en superficie de vesículas oscuras. Diám. $140 \mathrm{~mm}$. GRUPO 10. $\left(\mathrm{n}^{\circ}\right.$ $16.548 / 1)$.

\section{Metal}

12. Placa. Hierro. Placa triangular que conserva un clavo alojado junto al extremo más ancho; sección plana progresivamente ensanchada hacia el vértice, en forma semejante a algunas piezas de bisagra. Clavo: cabeza ovalada y espigo de sección cuadrangular. Estado de conservación: Regular, se conserva incompleta. $\quad\left(n^{\circ} \quad 14878\right)$ 


\section{Numismática}

\begin{tabular}{|c|c|c|}
\hline $\mathrm{N}^{\mathrm{o}} 12536$ & $500 / 540500 / 536$ & UE 4051 \\
\hline Peso: $1.18 \mathrm{gr}$ & Módulo: $15 \mathrm{~mm}$ & \\
\hline \multicolumn{3}{|c|}{ A: Busto femenino a la izquierda con atuendo imperial, casco y cetro [constantinopolis] } \\
\hline \multicolumn{3}{|c|}{ R: Victoria estante a la izquierda sobre proa portando cetro y apoyada en un escudo. En el exergo AQP } \\
\hline Constantino & 334-sept 335 & $\mathrm{AE} 4$ \\
\hline Ceca: Aquileia & Ref: RIC 129 & \\
\hline $\mathrm{N}^{\circ} 9326$ & $494 / 536$ & UE 1002 \\
\hline Peso: $1.32 \mathrm{gr}$ & Módulo: 15 mm & \\
\hline \multicolumn{3}{|c|}{ A: Busto a la derecha con doble diadema y coraza. CONSTANT-IVS PF AVG } \\
\hline \multicolumn{3}{|c|}{ R: Victoria avanzando a la izquierda con guirnalda y palma. VICTORI-A AVGG NN } \\
\hline Constantino II & h. 348 & $\mathrm{AE} 4$ \\
\hline Ceca: Roma & Ref: RIC 103a & \\
\hline $\mathrm{N}^{\circ} 14744$ & $500 / 536$ & UE 4050 \\
\hline Peso: $0.4 \mathrm{gr}$ & Módulo: $13 \mathrm{~mm}$ & \\
\hline \multicolumn{3}{|c|}{ A: Cabeza a la derecha $[\ldots]$} \\
\hline \multicolumn{3}{|c|}{ R: Dos soldados custodiando un estandarte [gloria exercitvs] } \\
\hline Familia constantina & $335-341$ & $\mathrm{AE} 4$ \\
\hline $\mathrm{N}^{\circ} 14739$ & $500 / 536$ & UE 4050 \\
\hline Peso: $1.39 \mathrm{gr}$ & Módulo: $16 \mathrm{~mm}$ & \\
\hline \multicolumn{3}{|c|}{ A: Busto a la derecha $[\ldots]$} \\
\hline \multicolumn{3}{|c|}{ R: Soldado con lanza y escudo atacando a un jinete caído [fel temp reparatio] } \\
\hline Familia constantina & $346-354$ & AE 4 \\
\hline $\mathrm{N}^{\mathrm{o}} 14854$ & $500 / 536$ & UE 4166 \\
\hline Peso: $1.20 \mathrm{gr}$ & Módulo: $15 \mathrm{~mm}$ & \\
\hline \multicolumn{3}{|c|}{ A: Busto a la derecha $[\ldots]$} \\
\hline \multicolumn{3}{|c|}{ R: Soldado con lanza y escudo atacando a un jinete caído [fel temp reparatio] } \\
\hline Familia constantina & $346-354$ & $\mathrm{AE} 4$ \\
\hline
\end{tabular}




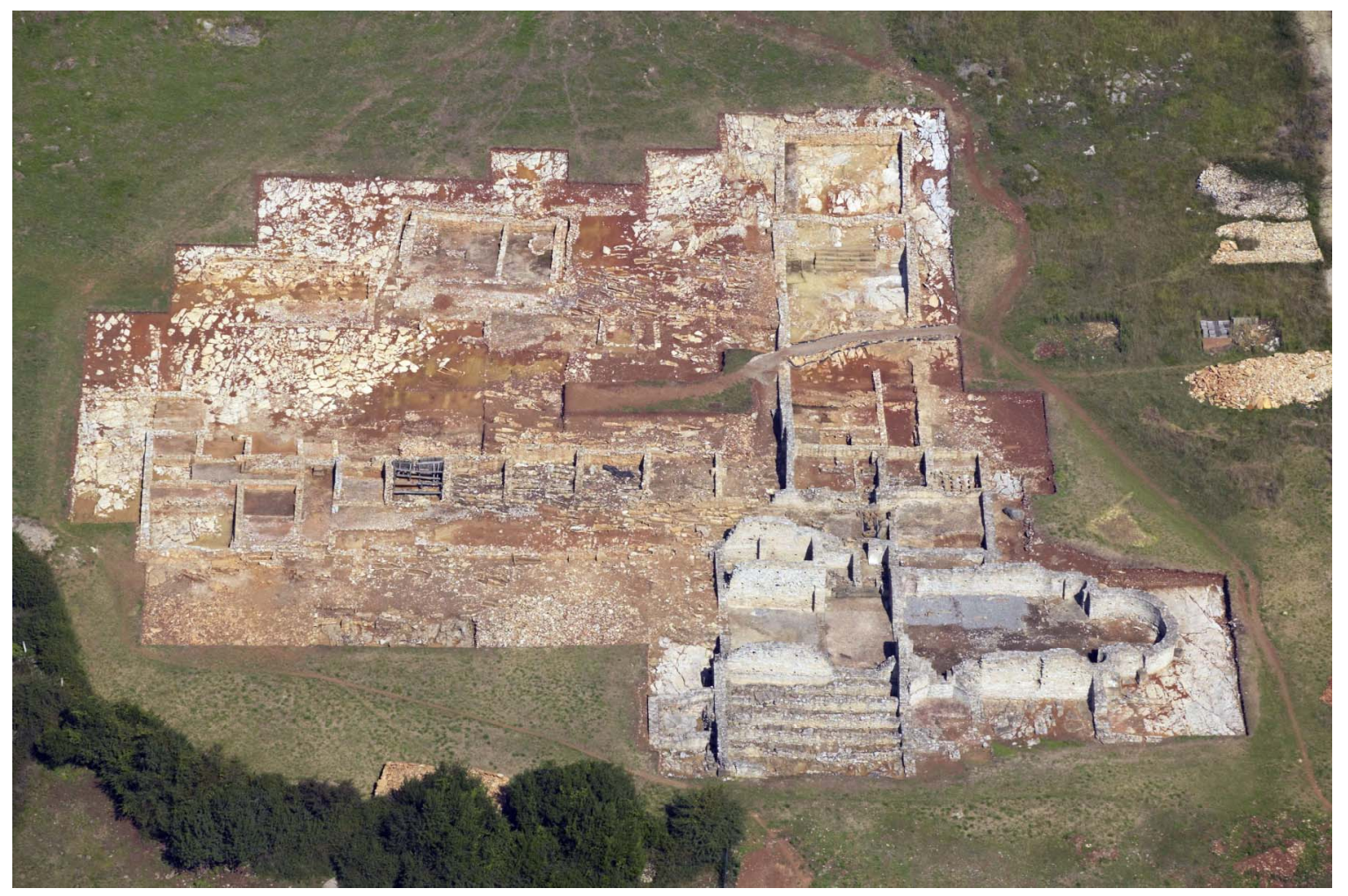

Fig. 1: Vista aérea de la villa de Veranes durante el proceso de excavación 


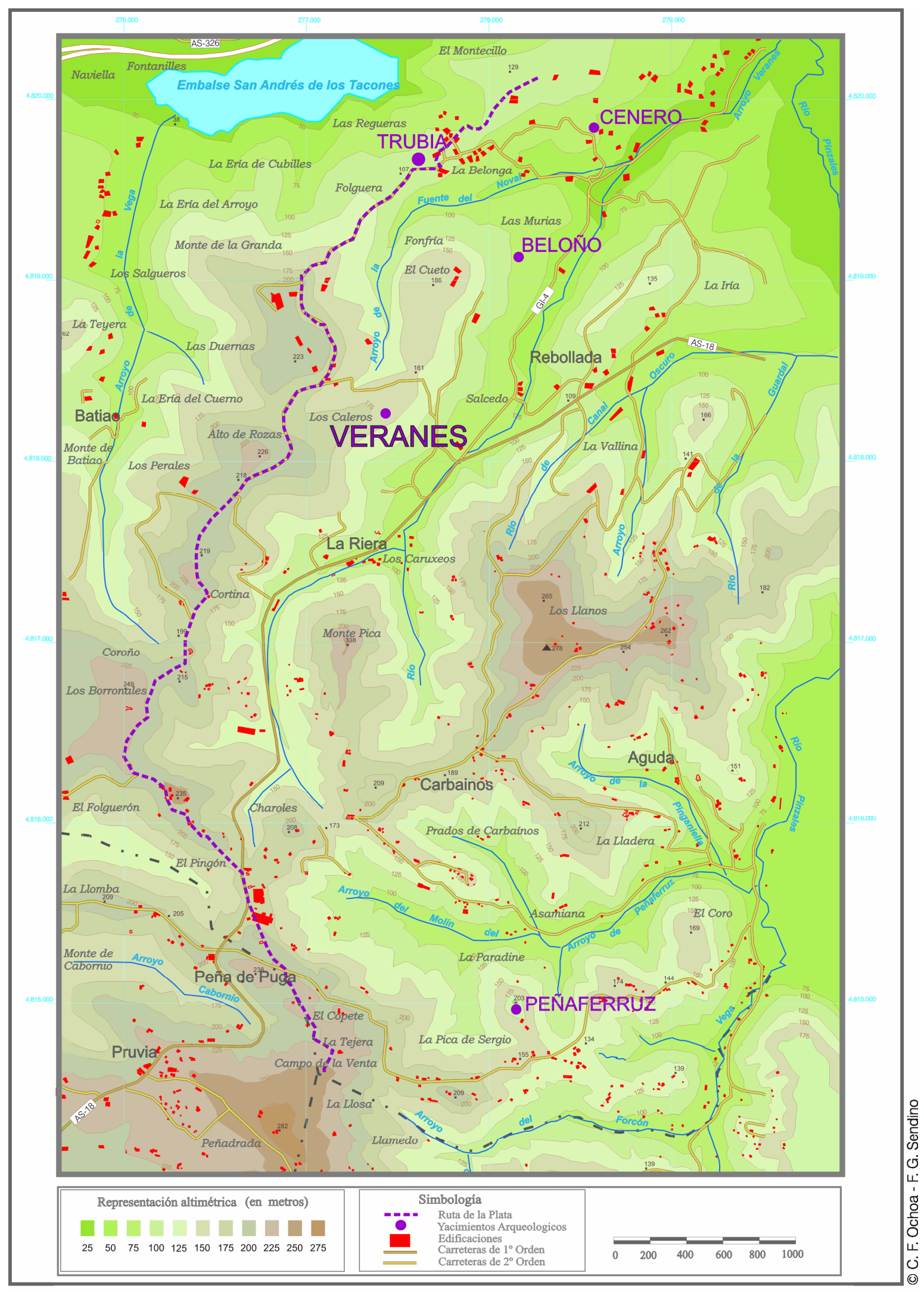

Fig. 2: Localización de la villa de Veranes en relación con el Ramal Transmontano de la Ruta de la Plata y los yacimientos arqueológicos romanos y medievales próximos. 


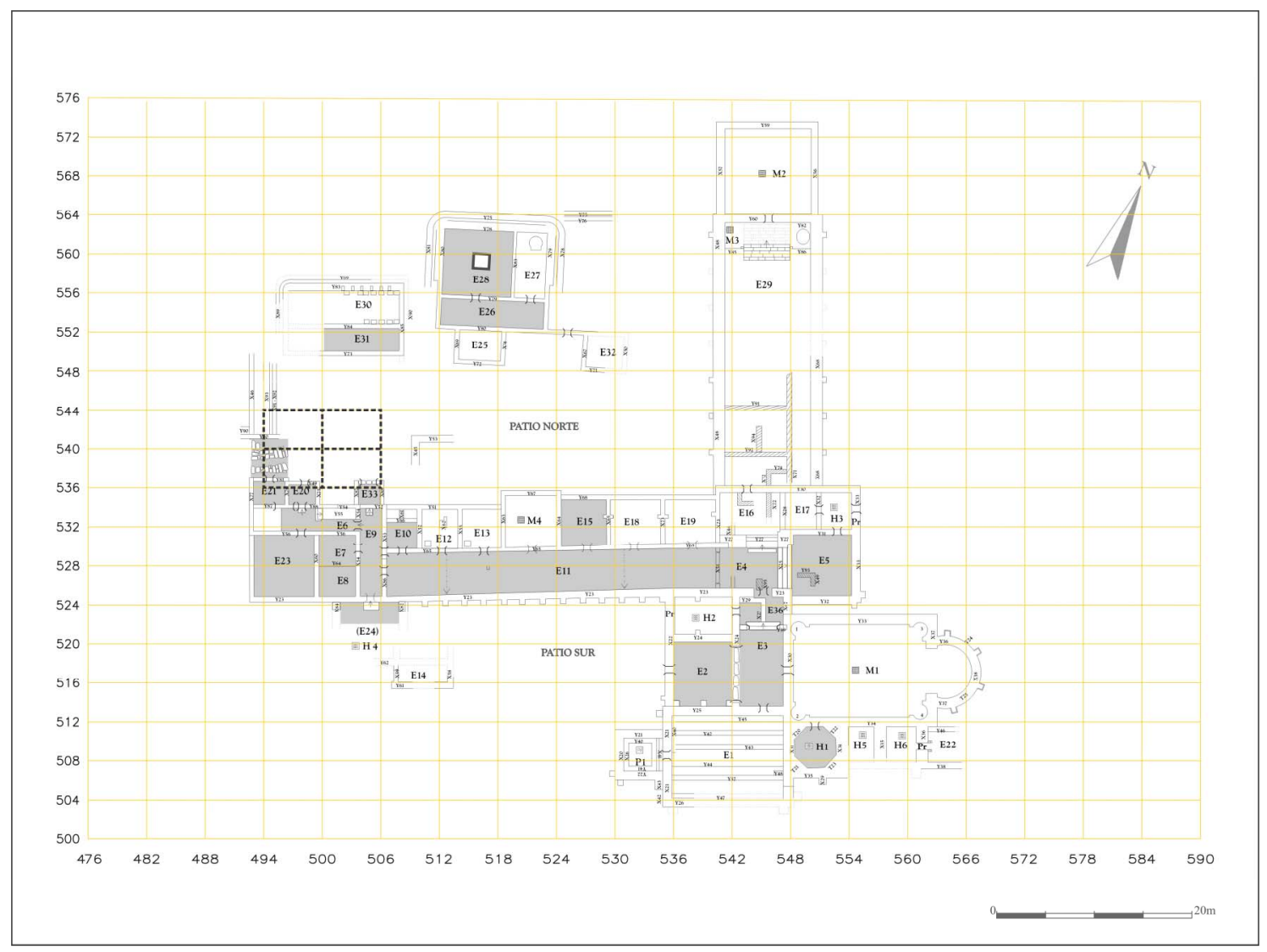

Fig. 3: Planta general de Veranes con indicación de la zona de estudio. 


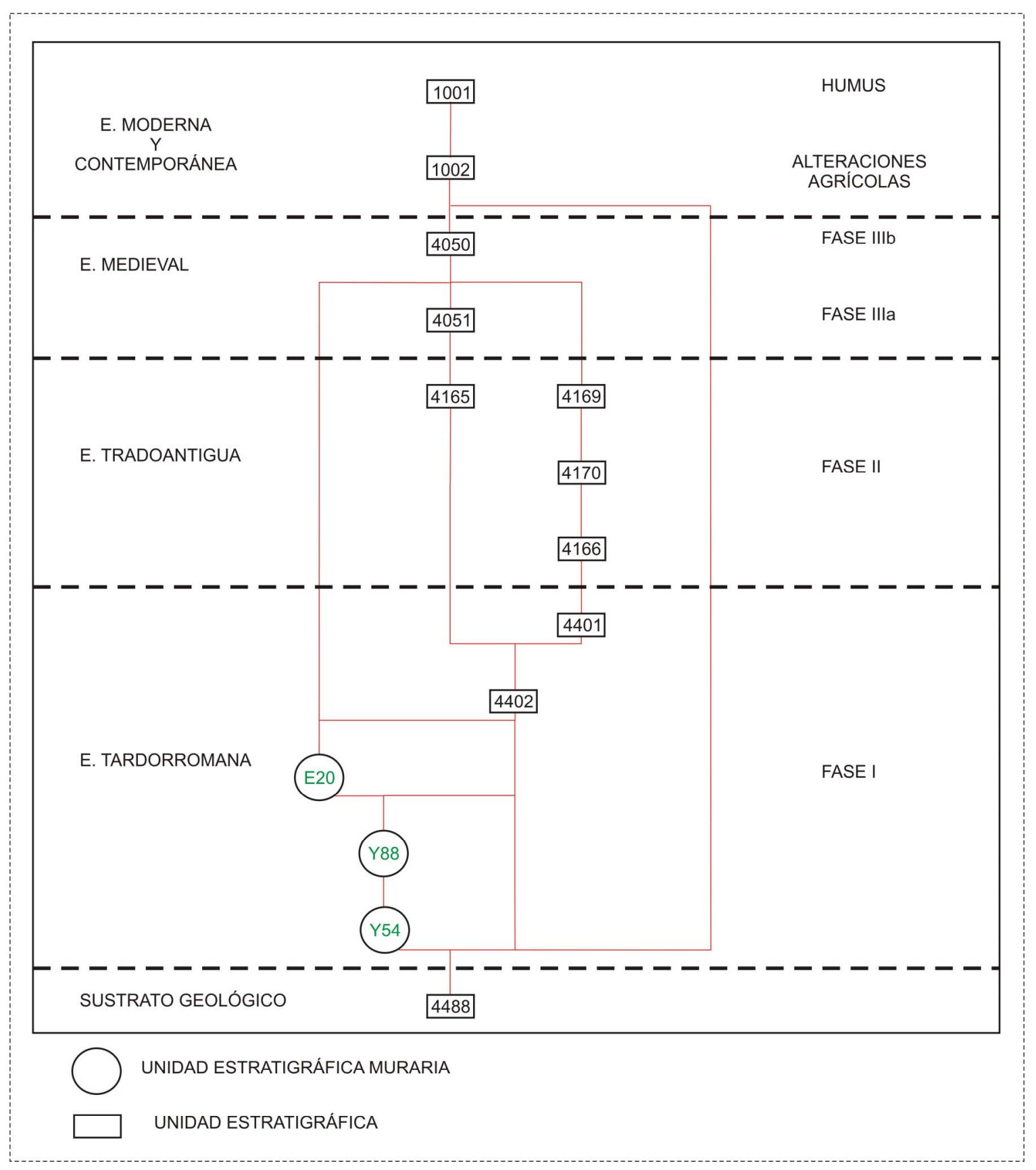

Fig. 4: Diagrama estratigráfico 


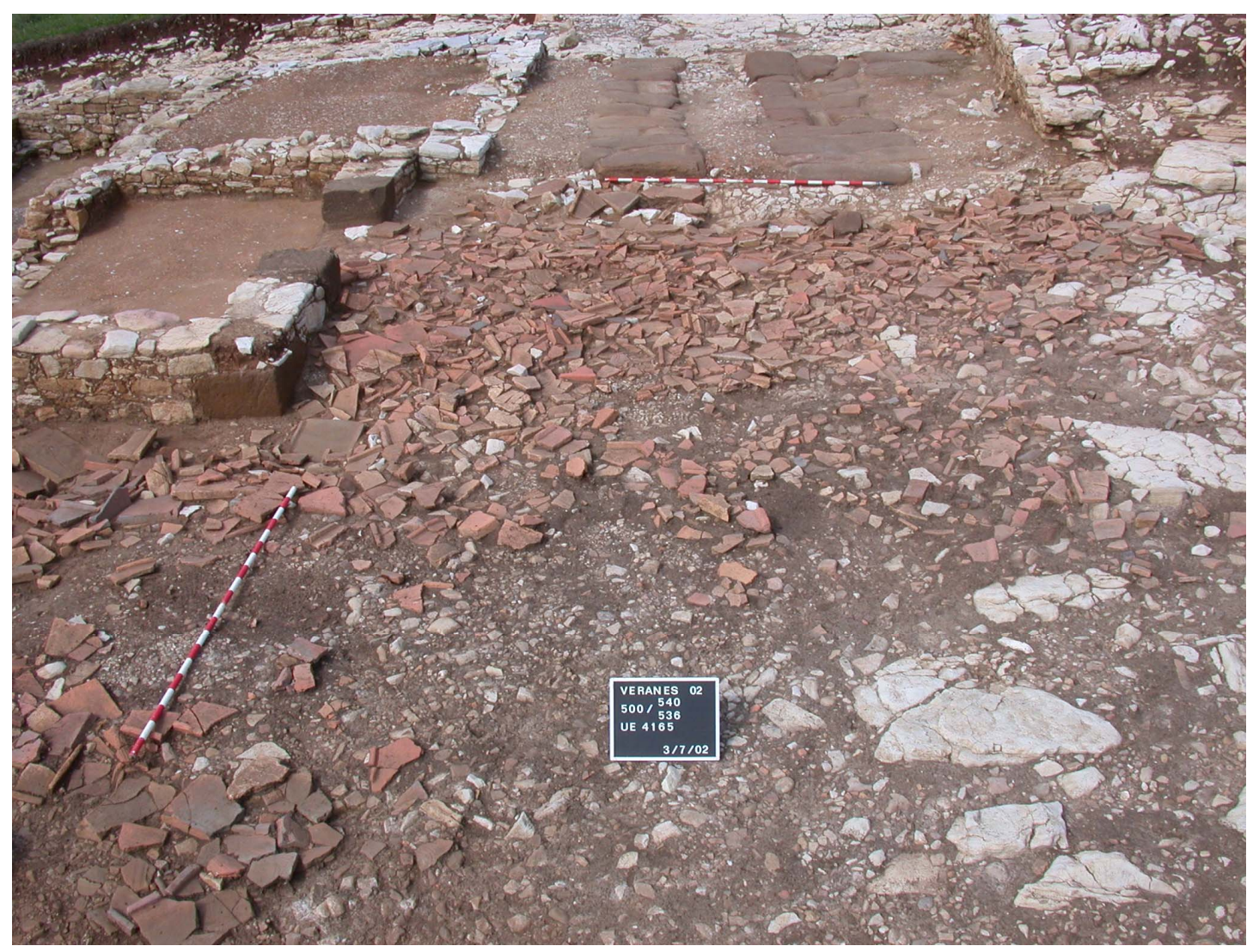

Fig. 5: Proceso de excavación de la zona de la puerta de la villa. Unidad estratigráfica de último uso y abandono del espacio.

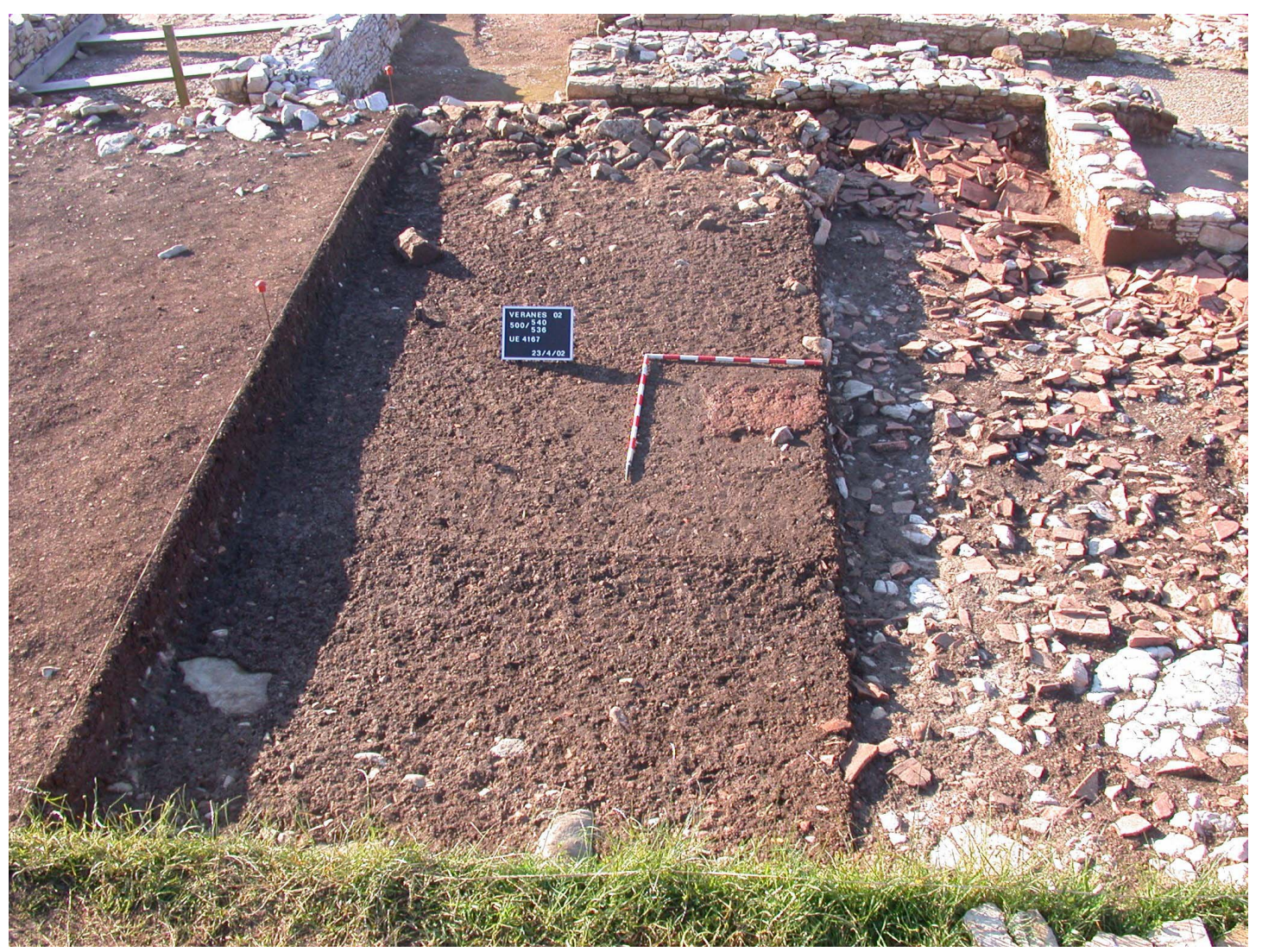

Fig. 6: Restos de una estructura de combustión localizada en los niveles medievales. 


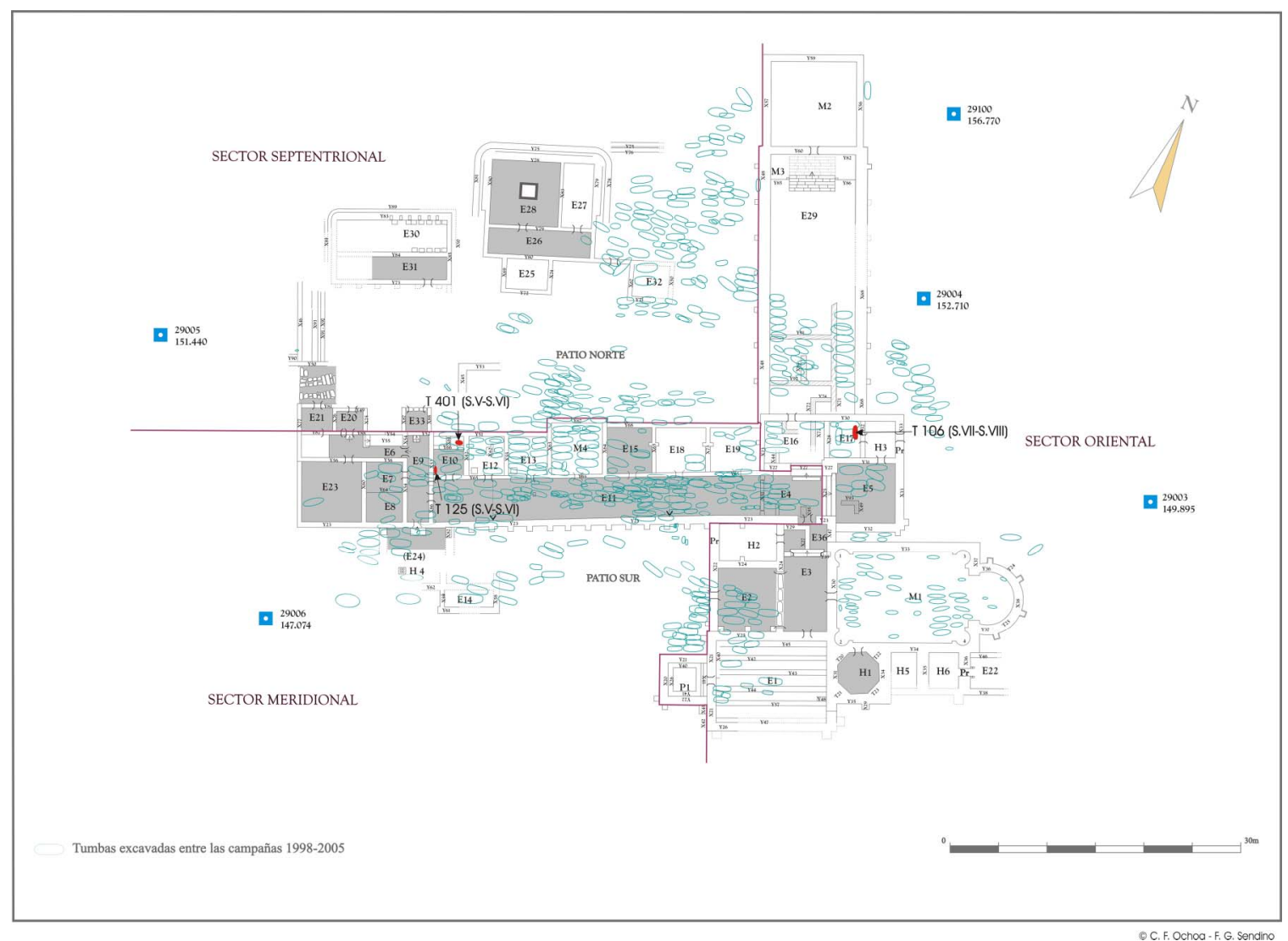

Fig. 7: Localización de los enterramientos tardoantiguos excavados en Veranes 

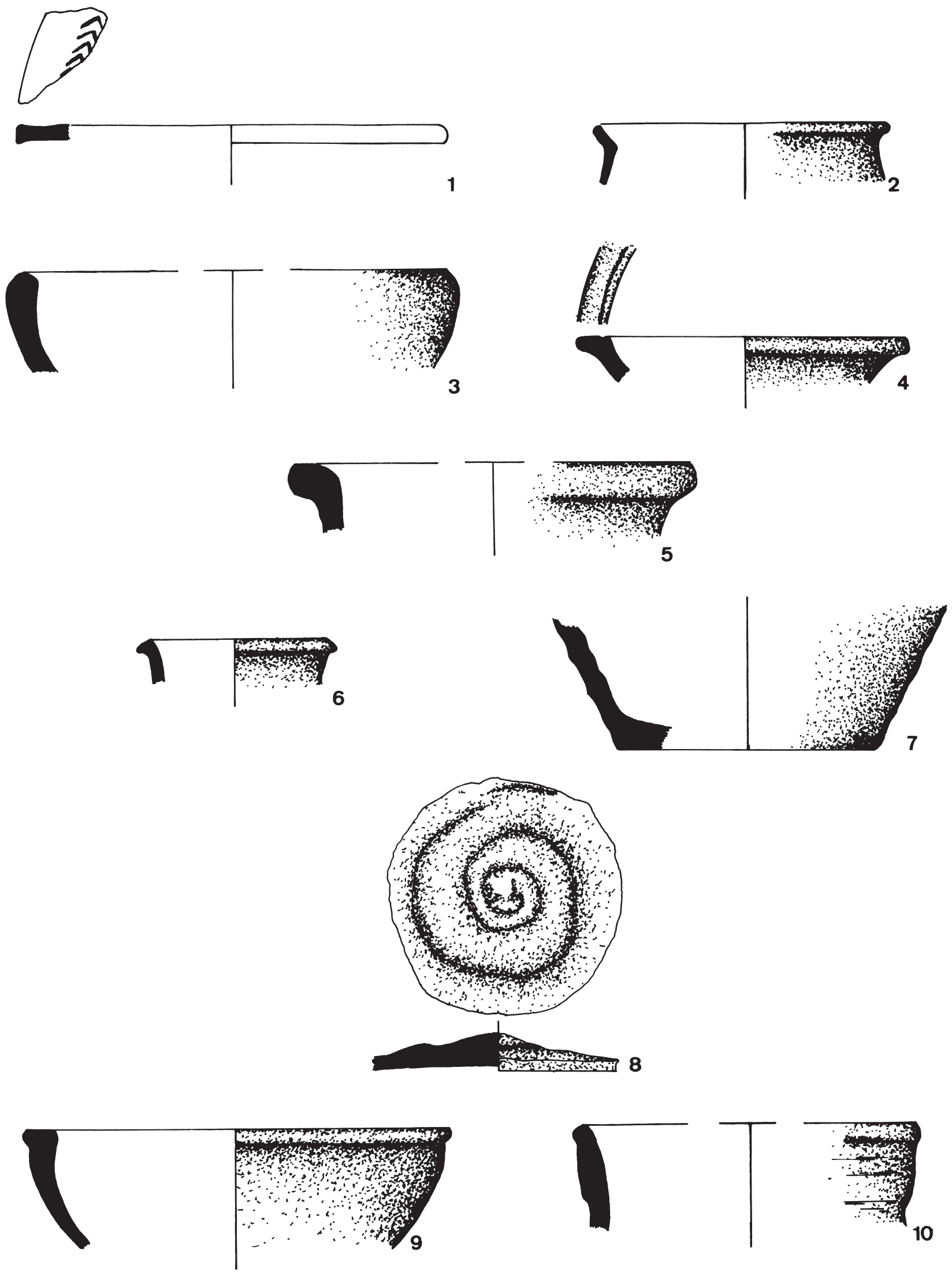

0

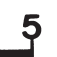

FIG. 8.U.E 1002: 1. T.S.H.T., 2. C.C.R (G.1), 3. C.C.R. (G.2), 4. C.C.R. (G.3), 5. C.C.R. (G.6), 6-8. C.MEDIEVAL (G.A), 9. C.MEDIEVAL (G.B), 10. C.MEDIEVAL (G.C). 

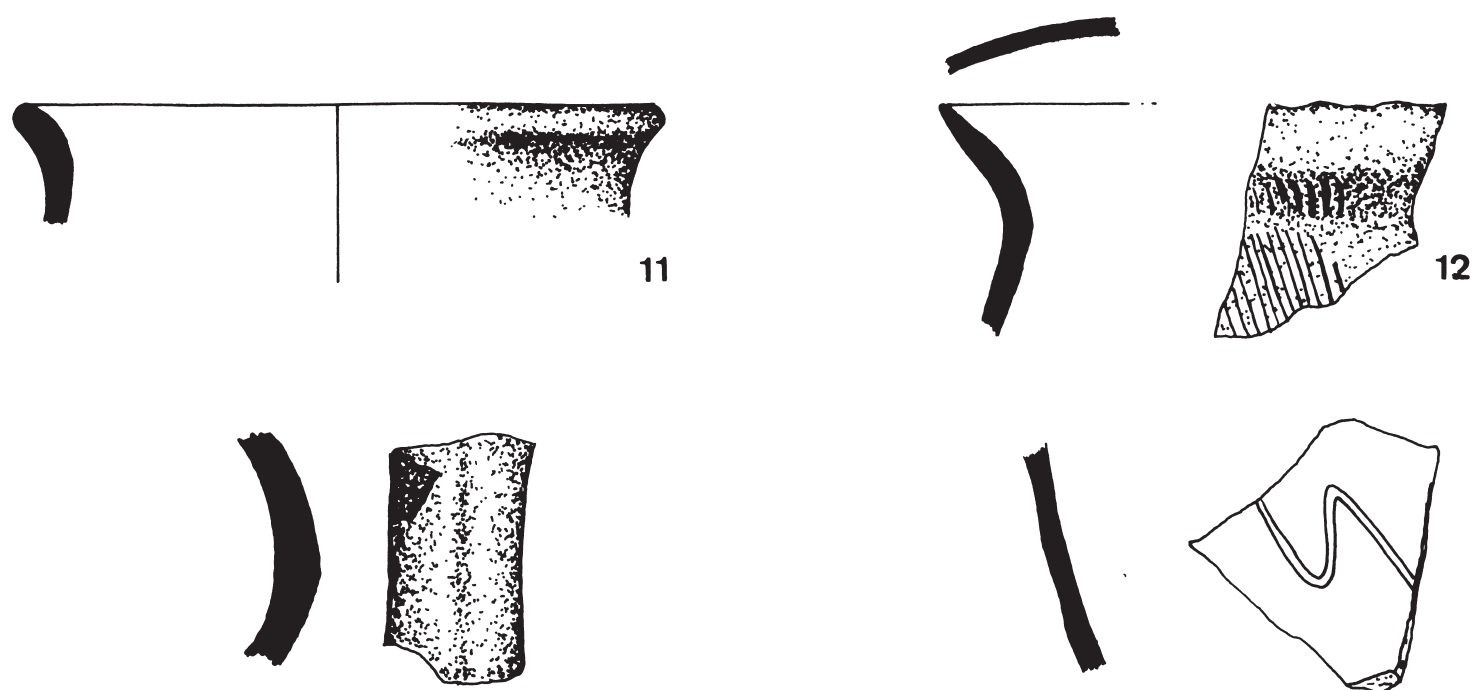

13
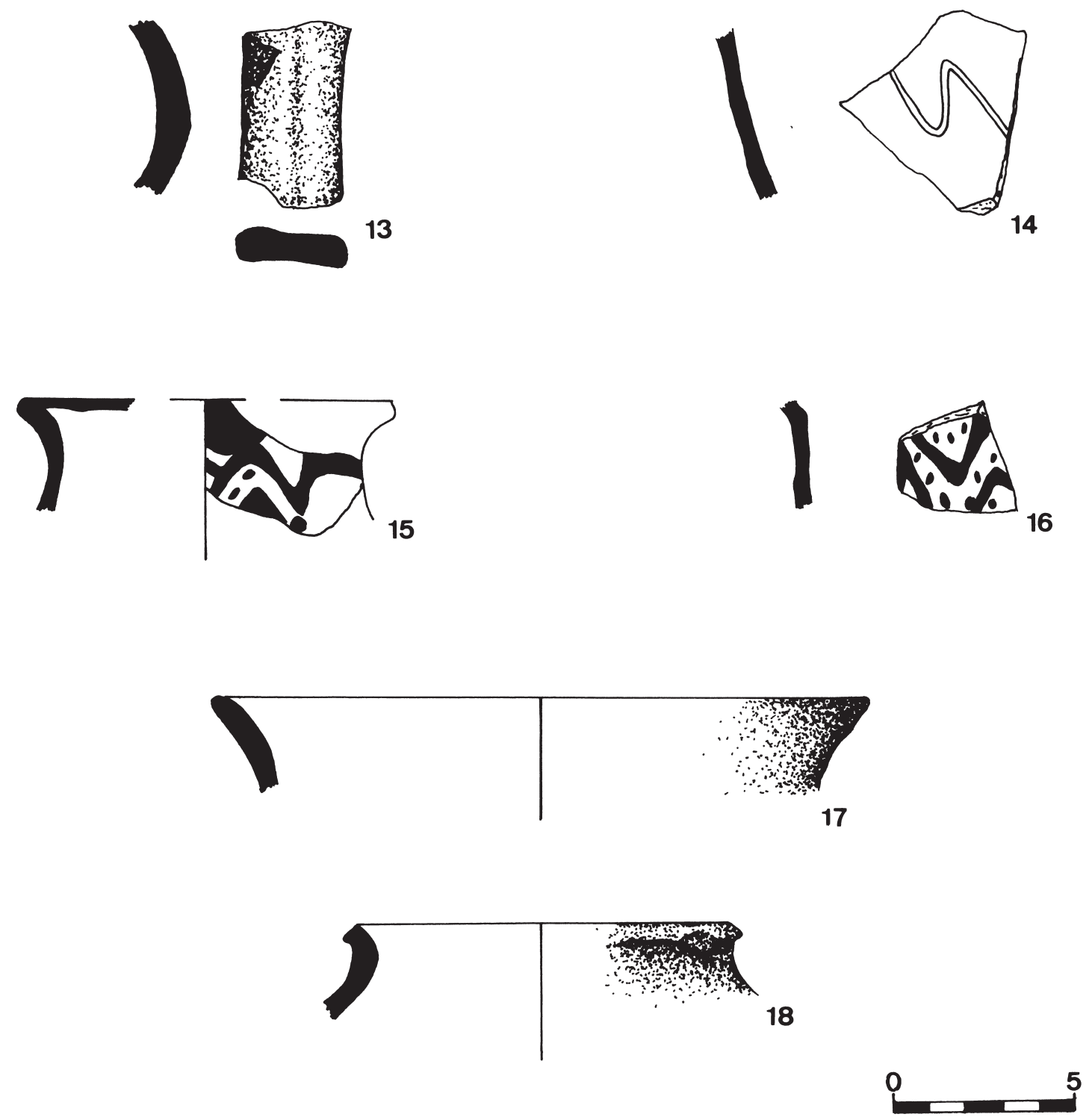

FIG. 9.

U.E 1002: 11-16. C.MEDIEVAL (G.C), 17-18. C.MEDIEVAL (G.D). 

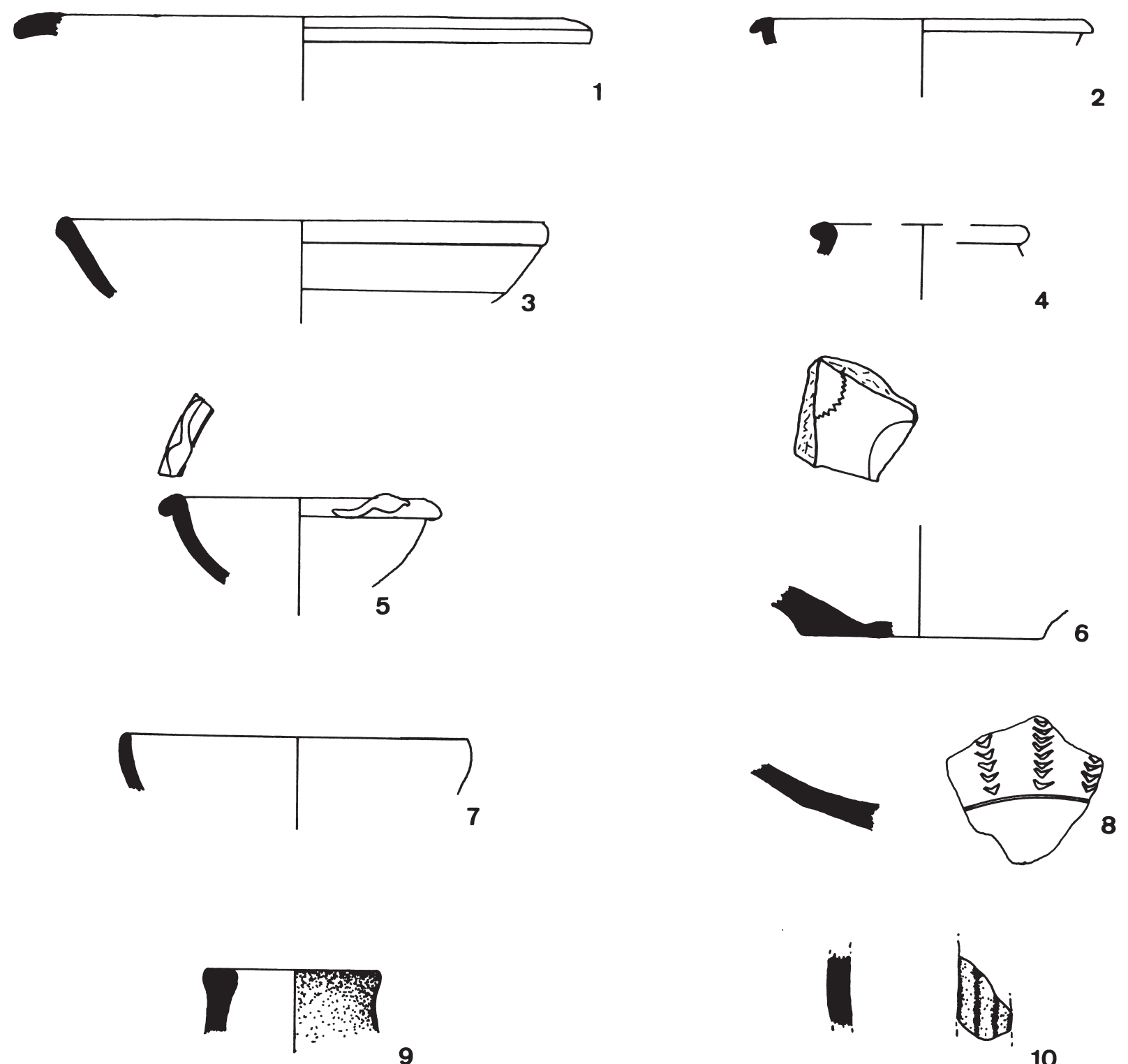

10
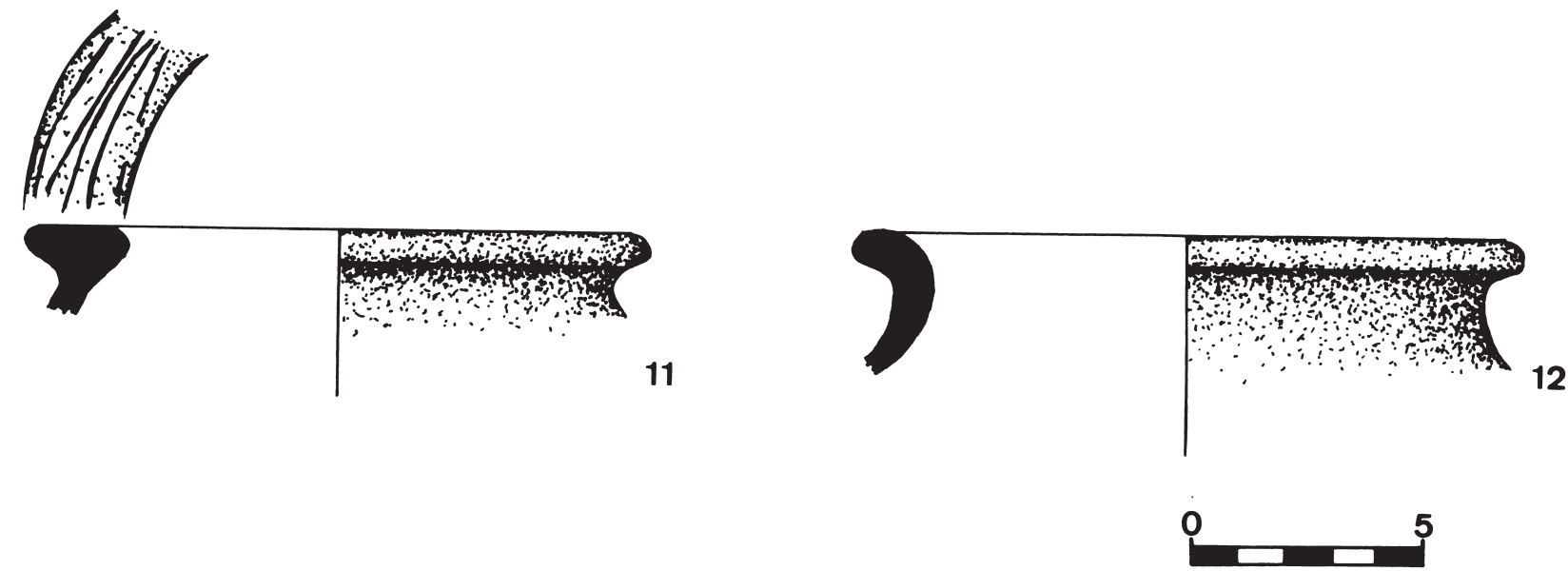

FIG. 10.

U.E 4050: 1-5. T.S.H., 6-8. T.S.H.T., 9-10. T.S.G.G.T., 11-12. C.C.R. (G.2). 

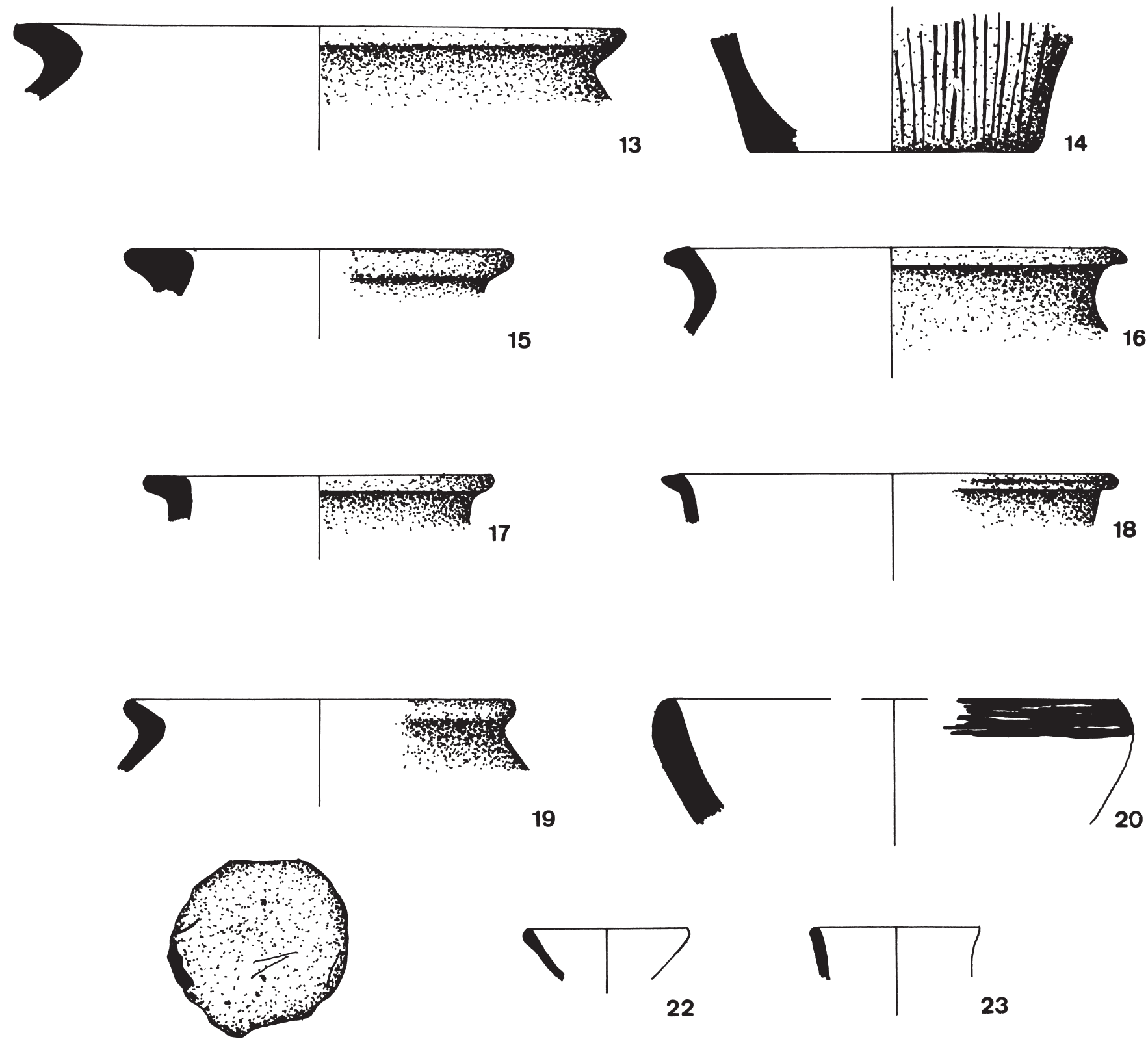

19
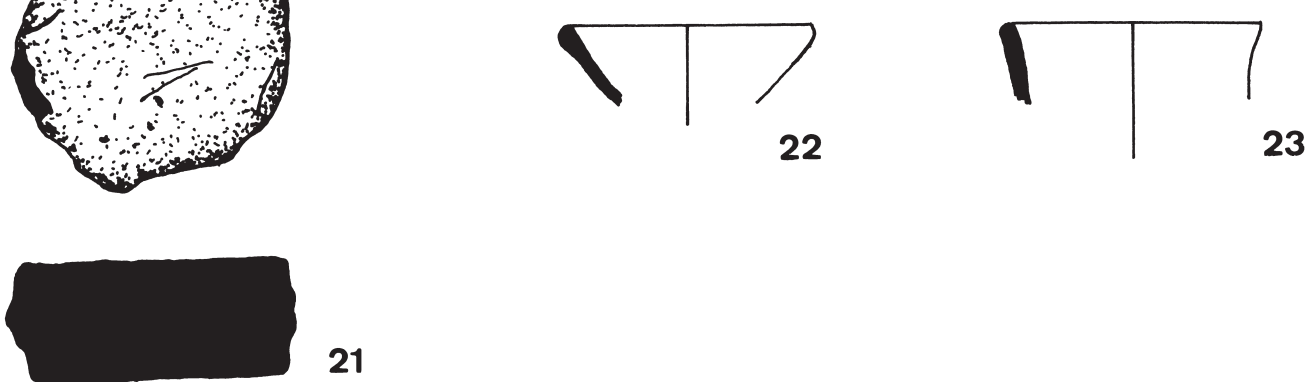

21
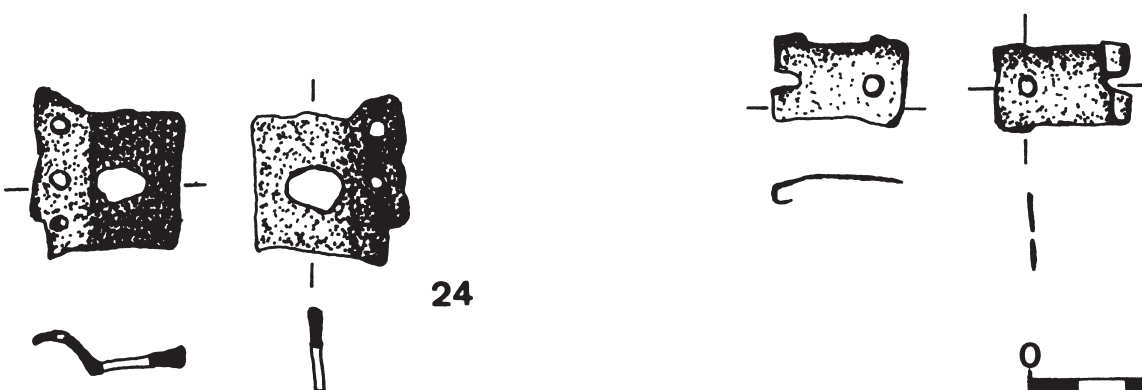

24

25

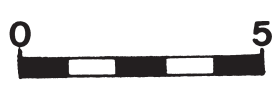

FIG. 11.

U.E 4050: 13-14. C.C.R (G.2), 15-18. C.C.R. (G.3), 19. C.C.R. (G.6), 20. C.R.PINTADA, 21. TAPADERA DE LATERICIO RECORTADO, 24. PLACA DE CINTURÓN, 25. PLACA DE CINTURÓN (Br). 


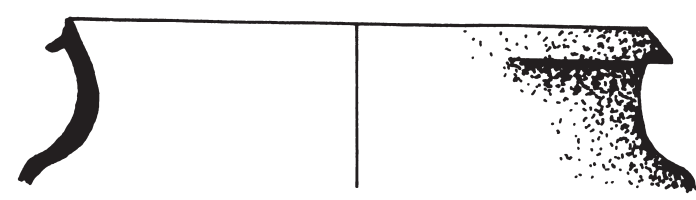

26

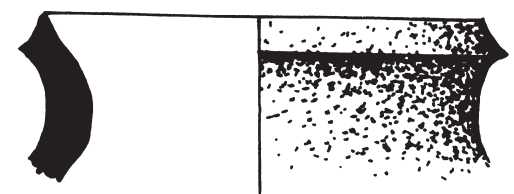

27
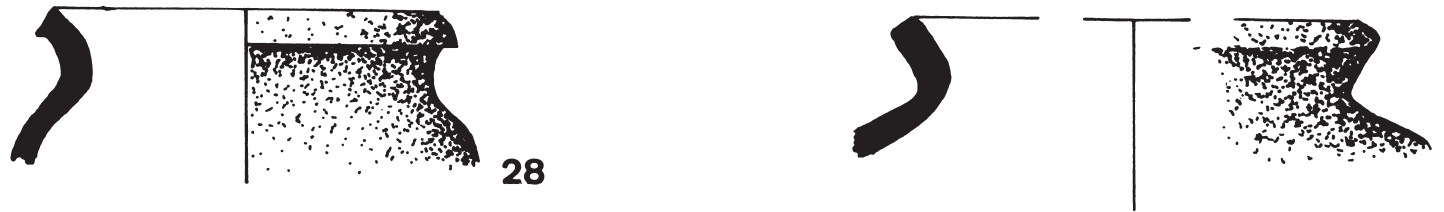

29
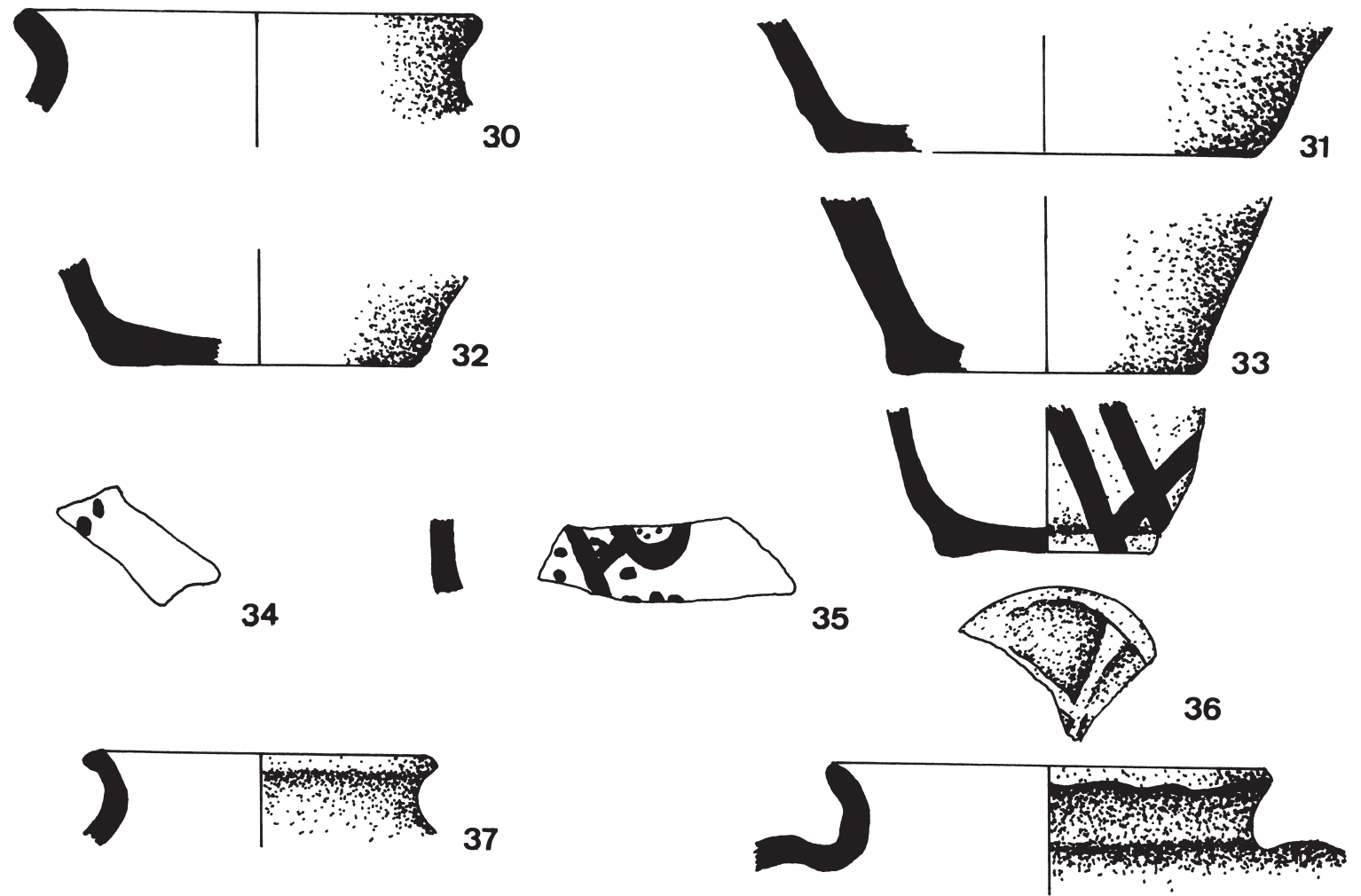

35

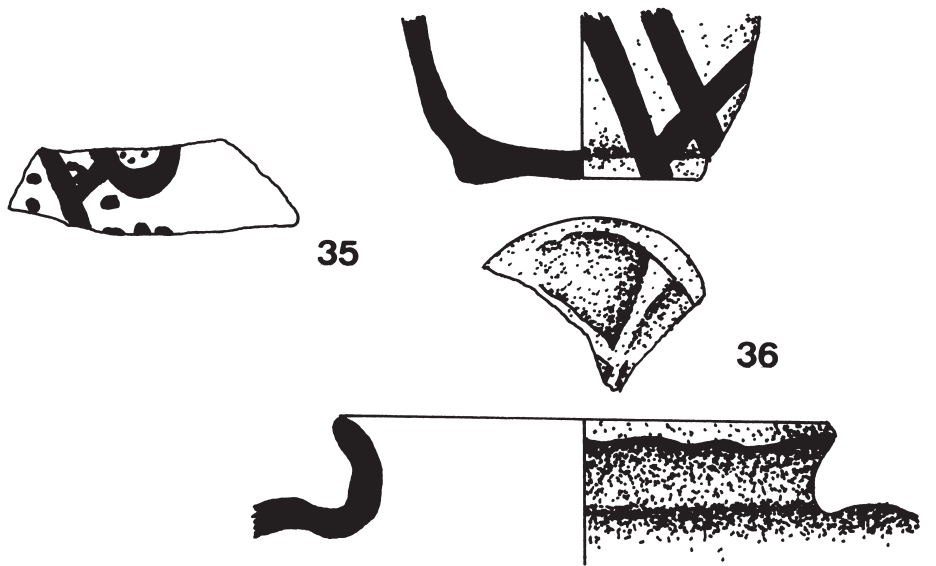

33

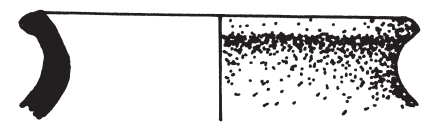

37
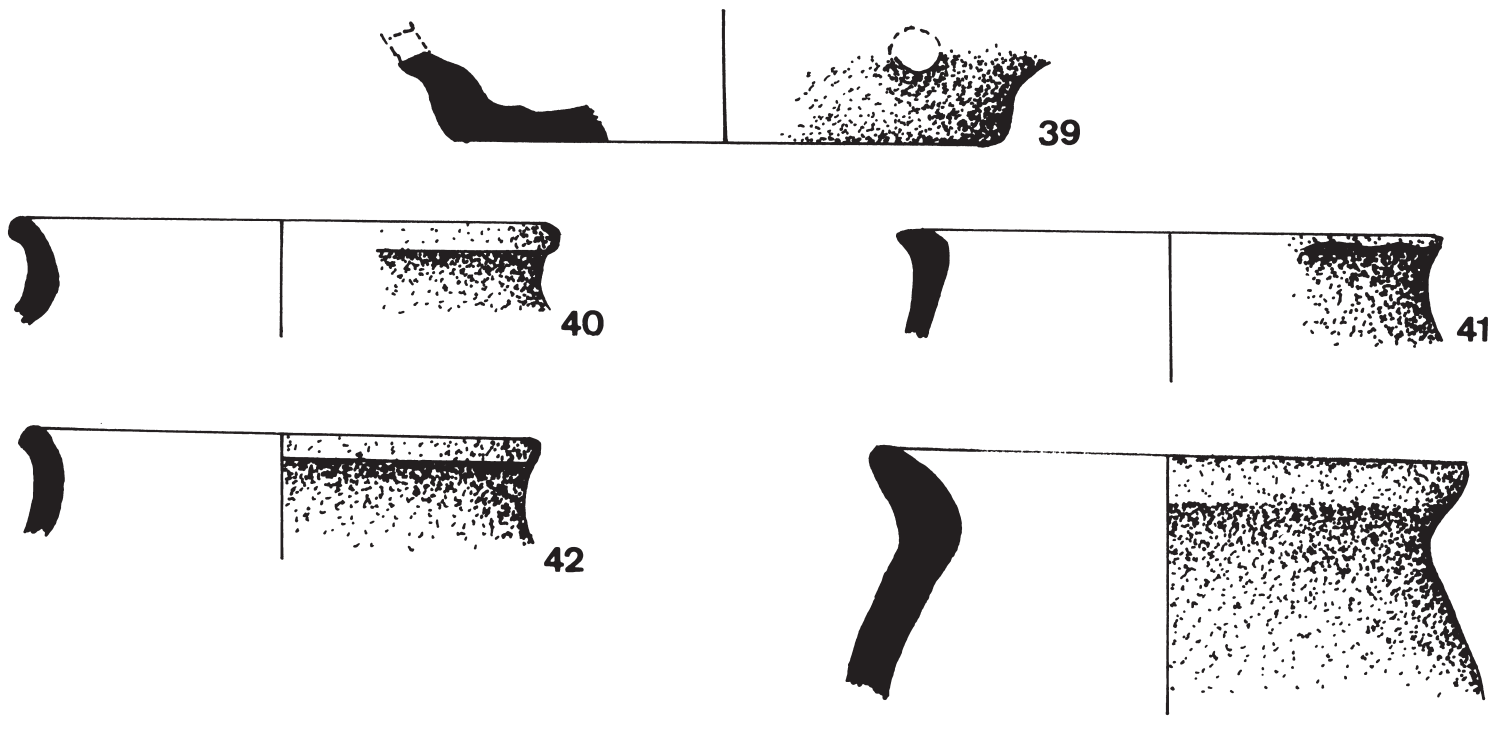

FIG. 12.

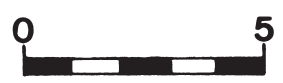

U.E 4050: 26. C.MEDIEVAL (G.A), 27-36. C.MEDIEVAL (G.C), 37-39. C.MEDIEVAL (G.AFÍN AL C), 40-41. C.MEDIEVAL (G.D), 42-43. C.MEDIEVAL (G.E). 

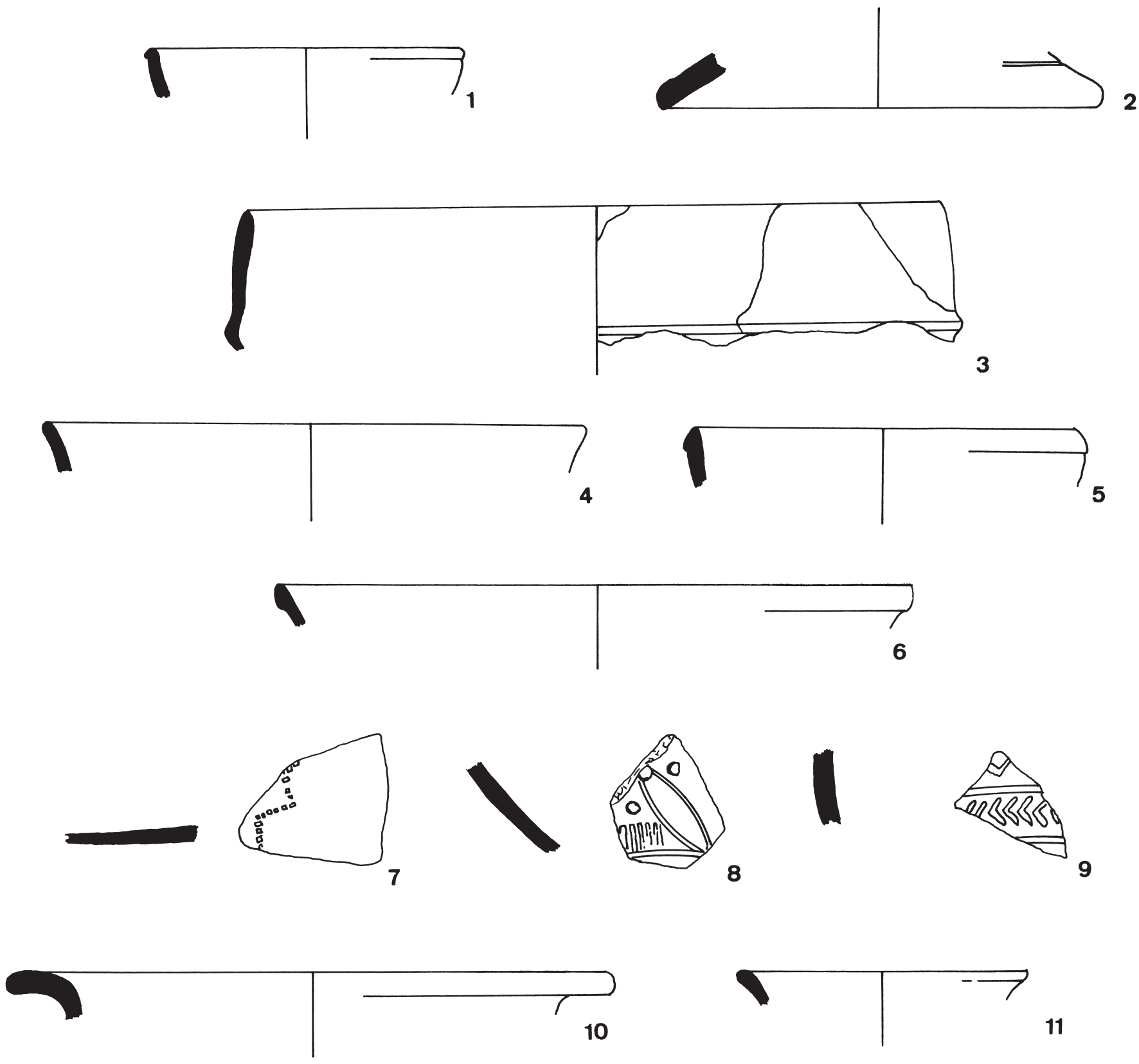

11

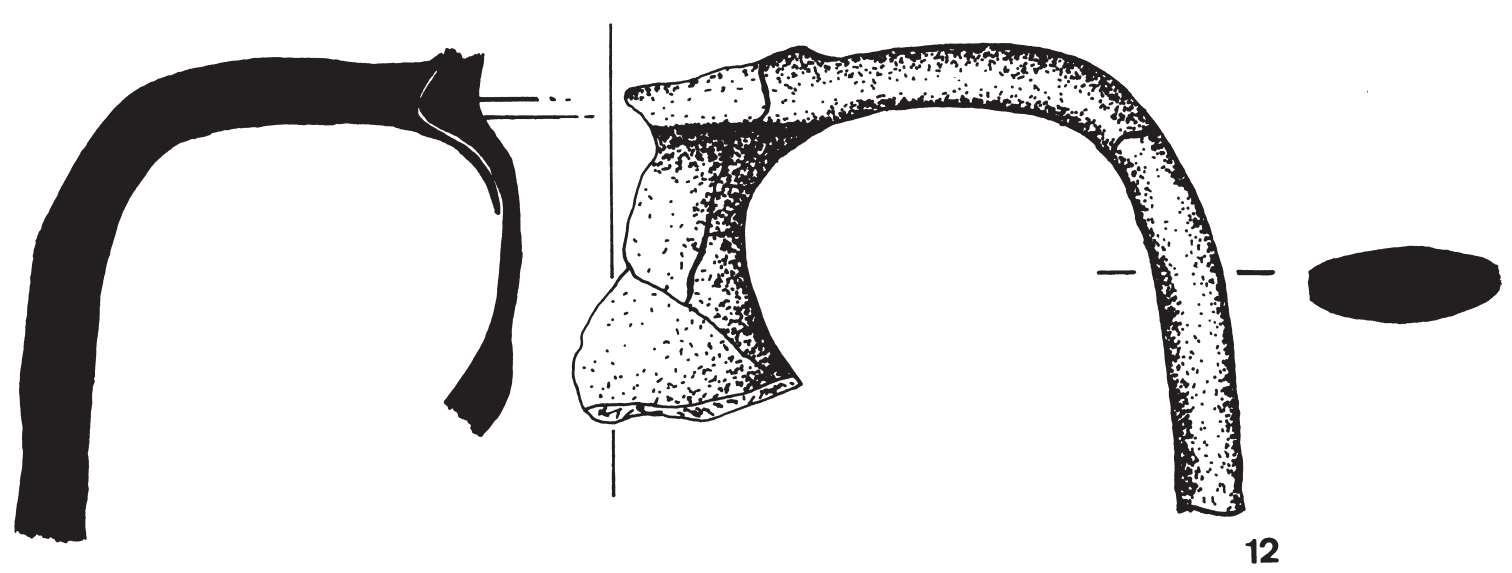

FIG. 13.

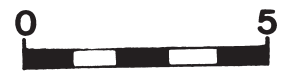

U.E 4051: 1-2. T.S.H., 3-9. T.S.H.T., 10-11. IMITACIÓN T.S.G.G.T., 12. ÁNFORA. 


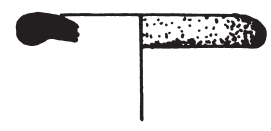

13
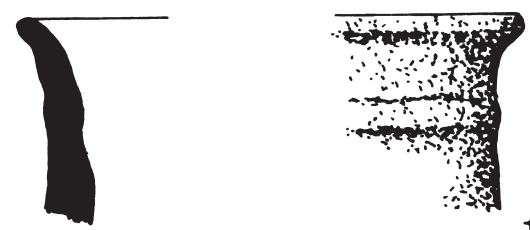

15
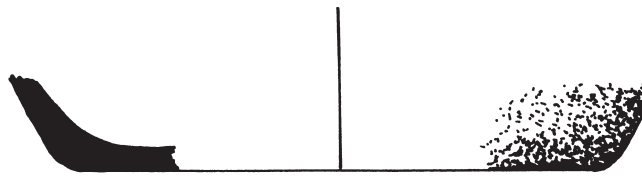
17

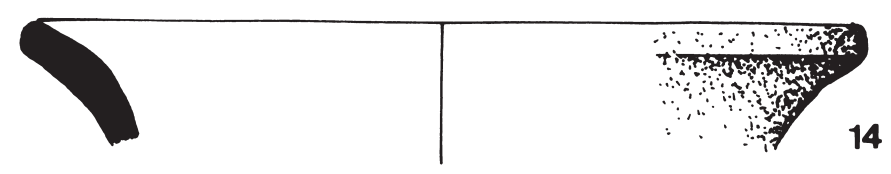

14

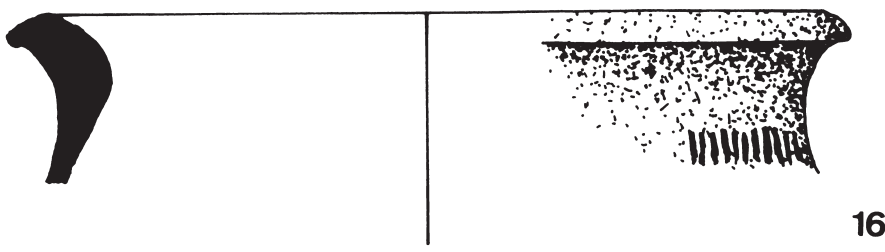

16
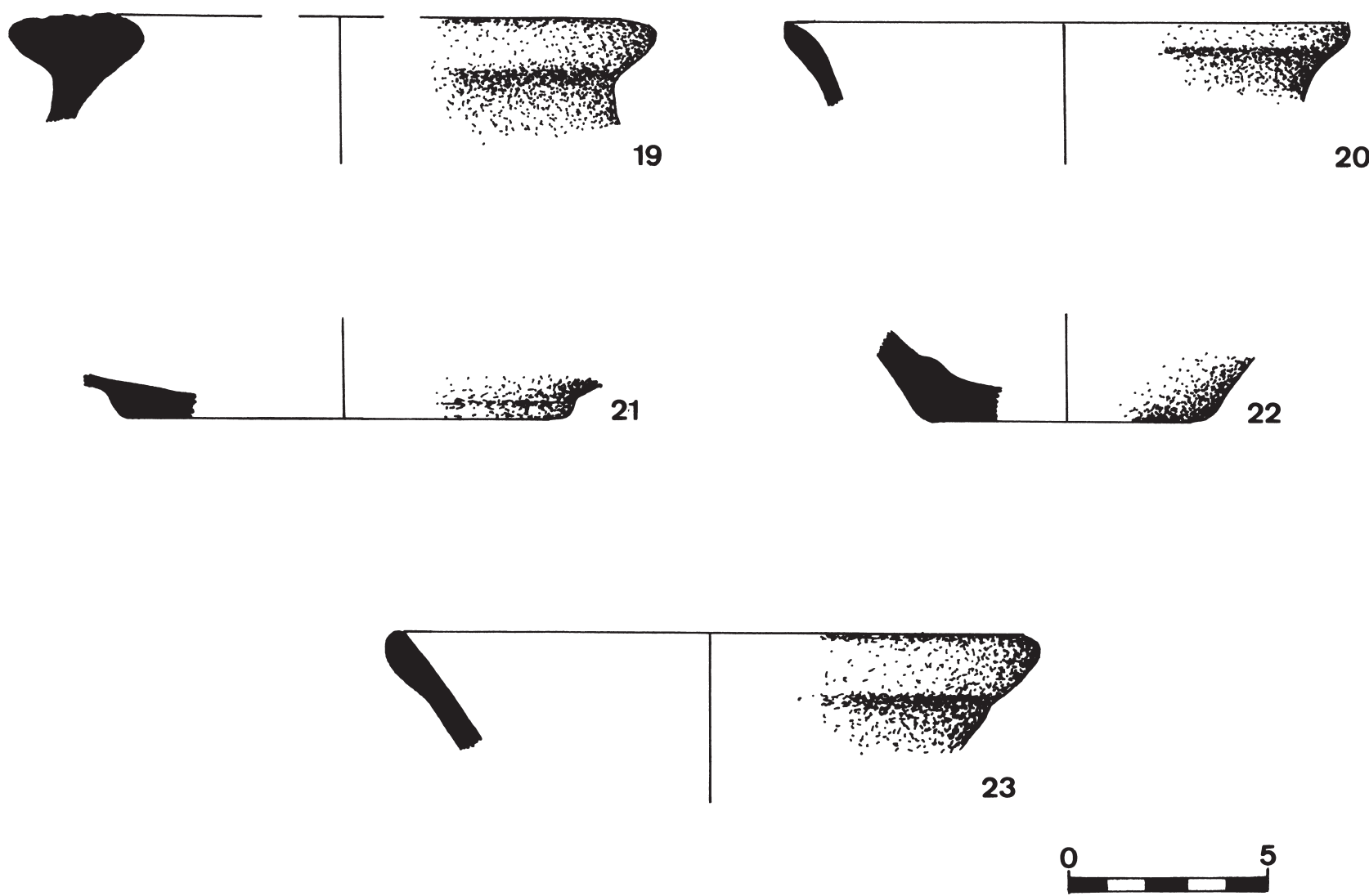

FIG. 14.

U.E 4051: 13. C.C.R (G.1), 14-18. C.C.R. (G.2), 19-22. C.C.R. (G.3), 23. C.C.R. (G.4). 


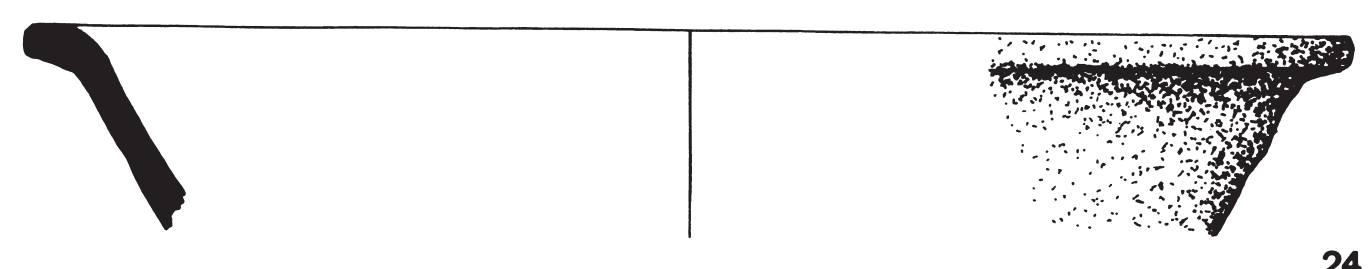

24

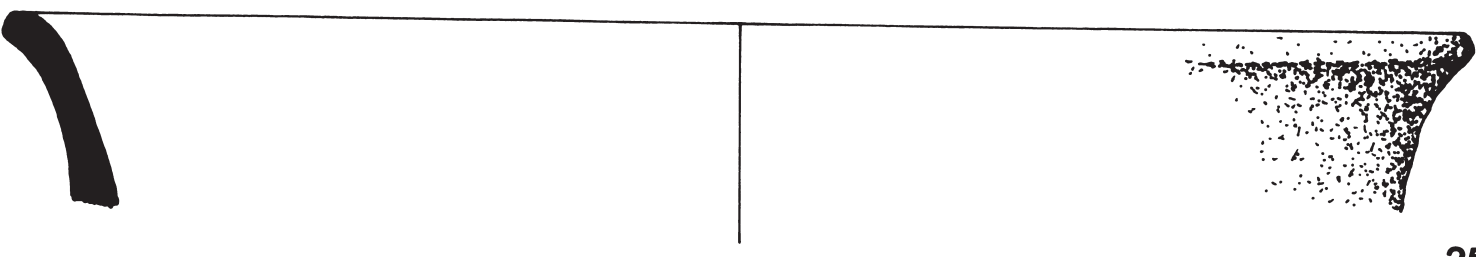

25
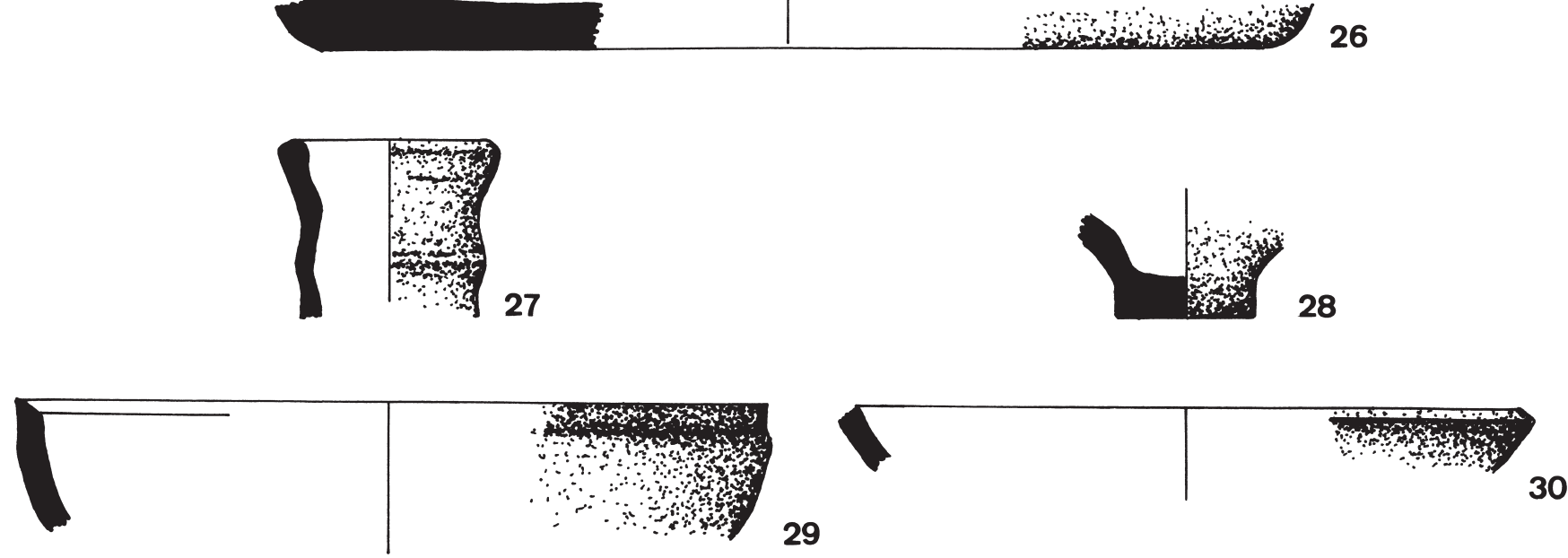

29
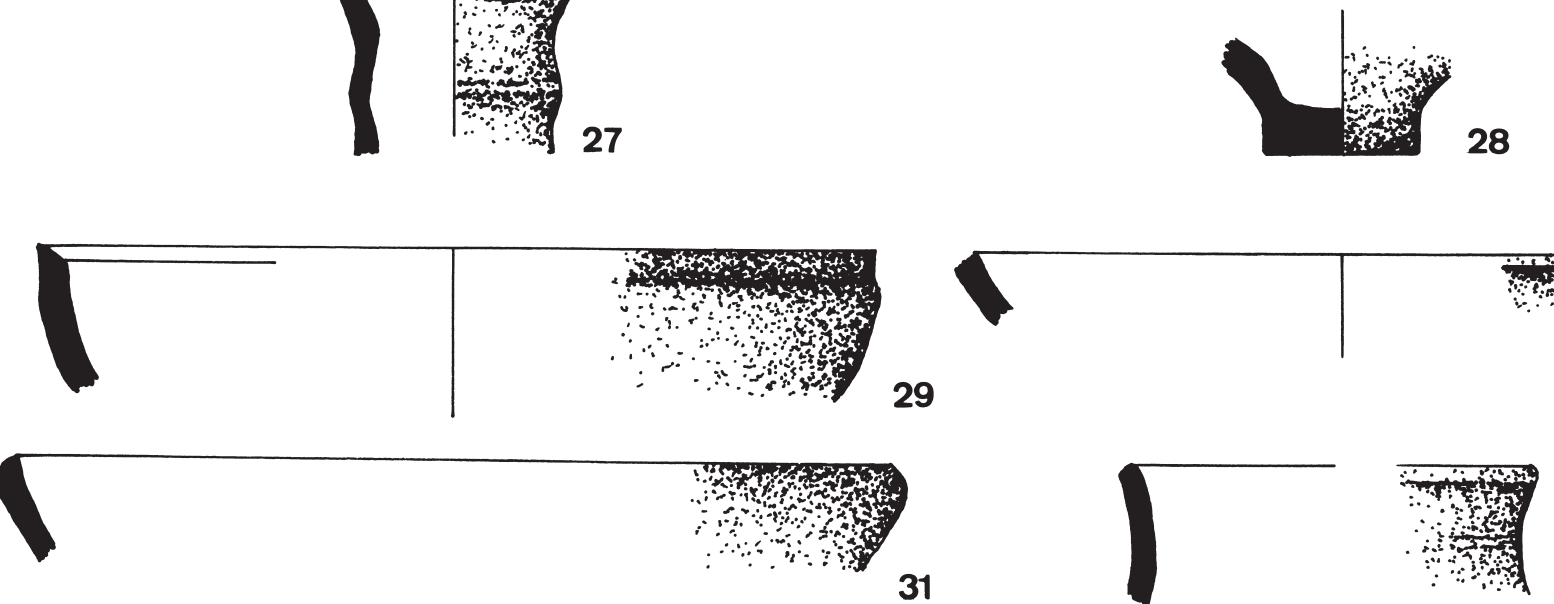

32
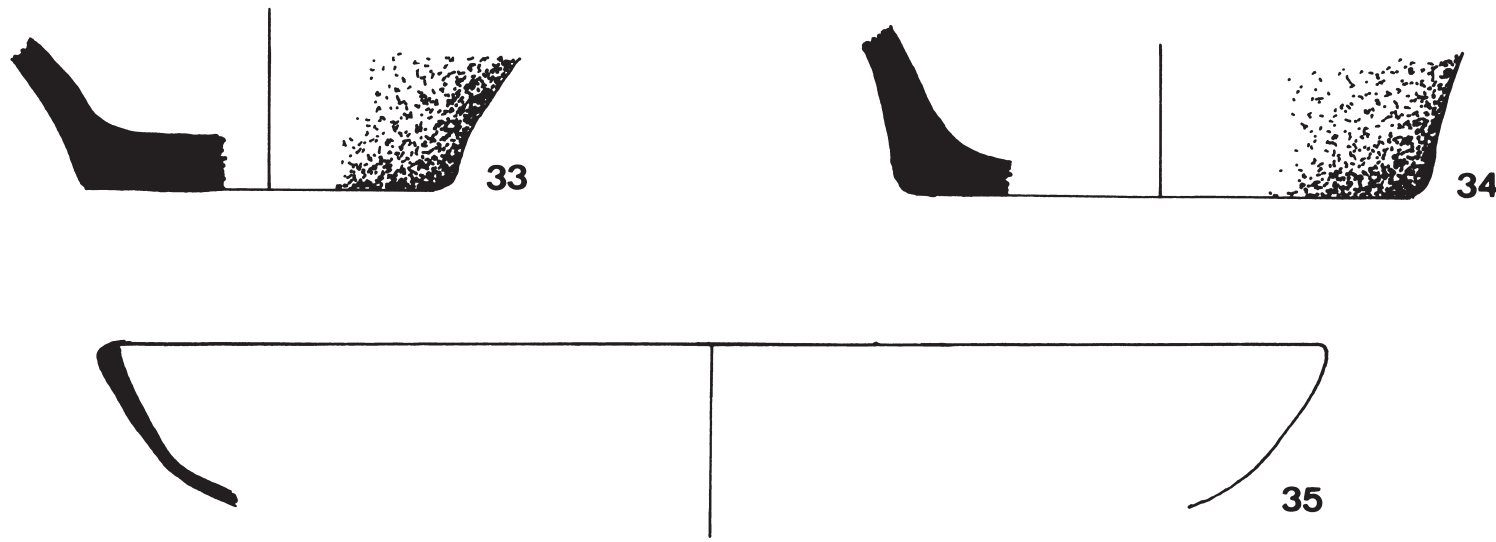

5

FIG. 15.

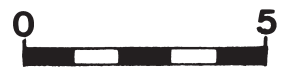

U.E 4051: 24-26. C.C.R (G.4), 27-28. C.C.R. (G.5), 29-34. C.C.R. (G.6), 35. VIDRIO. 

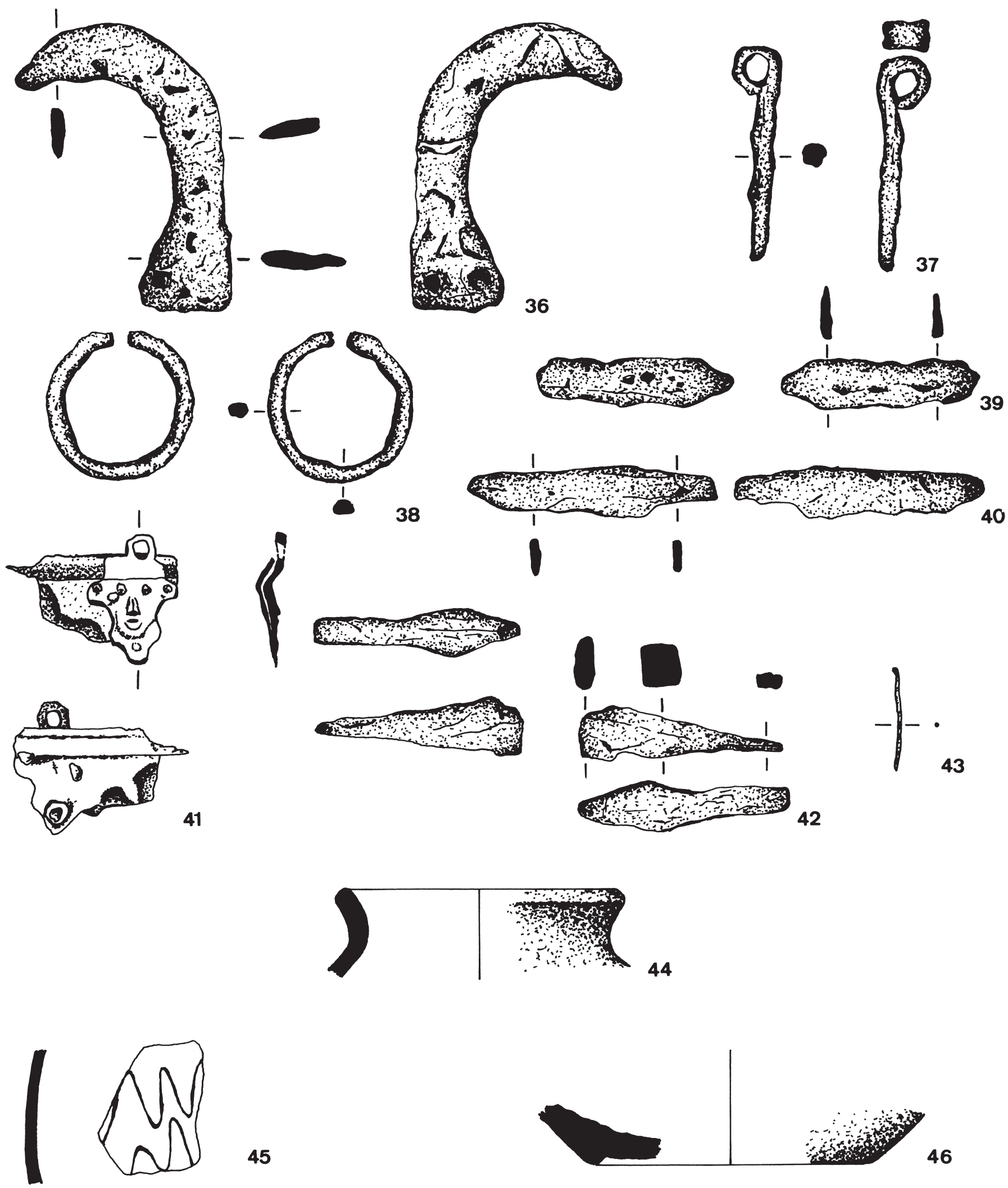

45

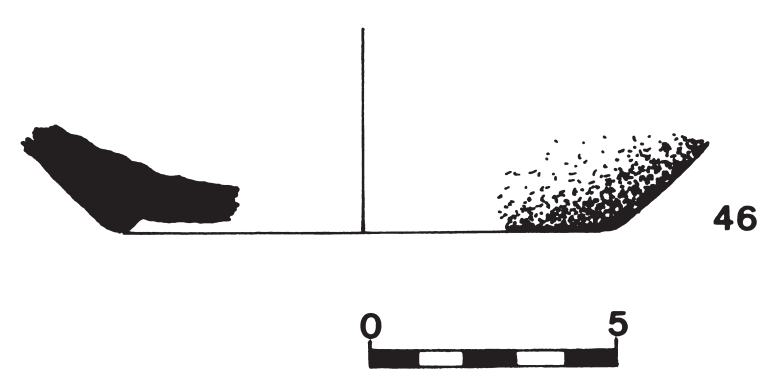

FIG. 16.

U.E 4051: 36. PODADERA (Fe), 37. GANCHO (Fe), 38. ARO (Fe), 39. CUCHILLO (Fe), 40.

CUCHILLO (Fe), 41. SíTULA (Br), 42. PICO (Fe), 43. AGUJA (Br), 44. C.MEDIEVAL (G.C), 45-46

C.MEDIEVAL (G.D). 

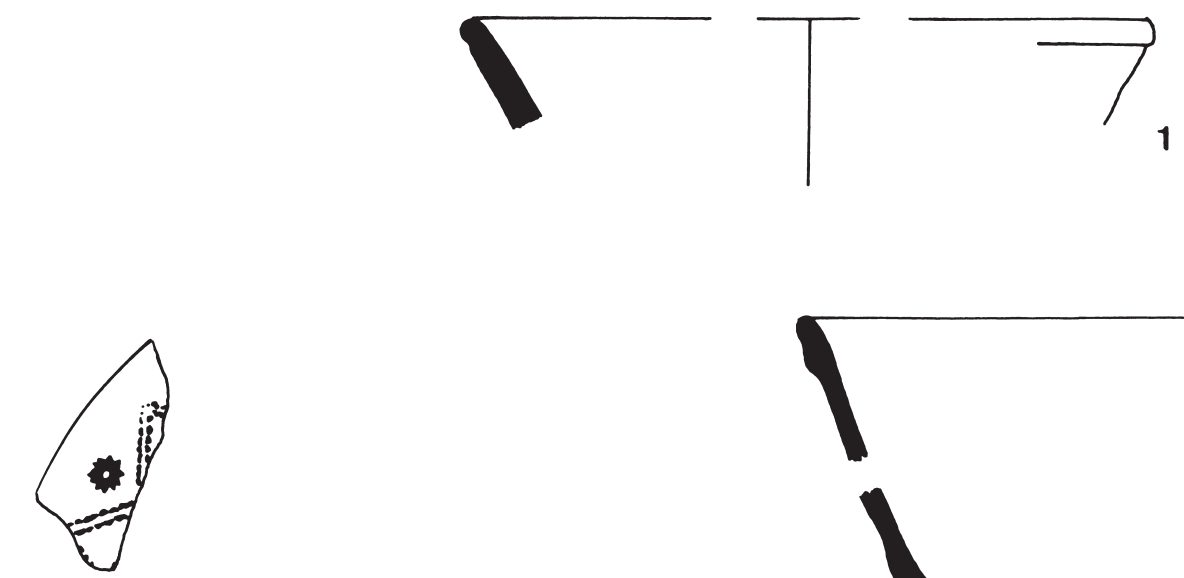

2
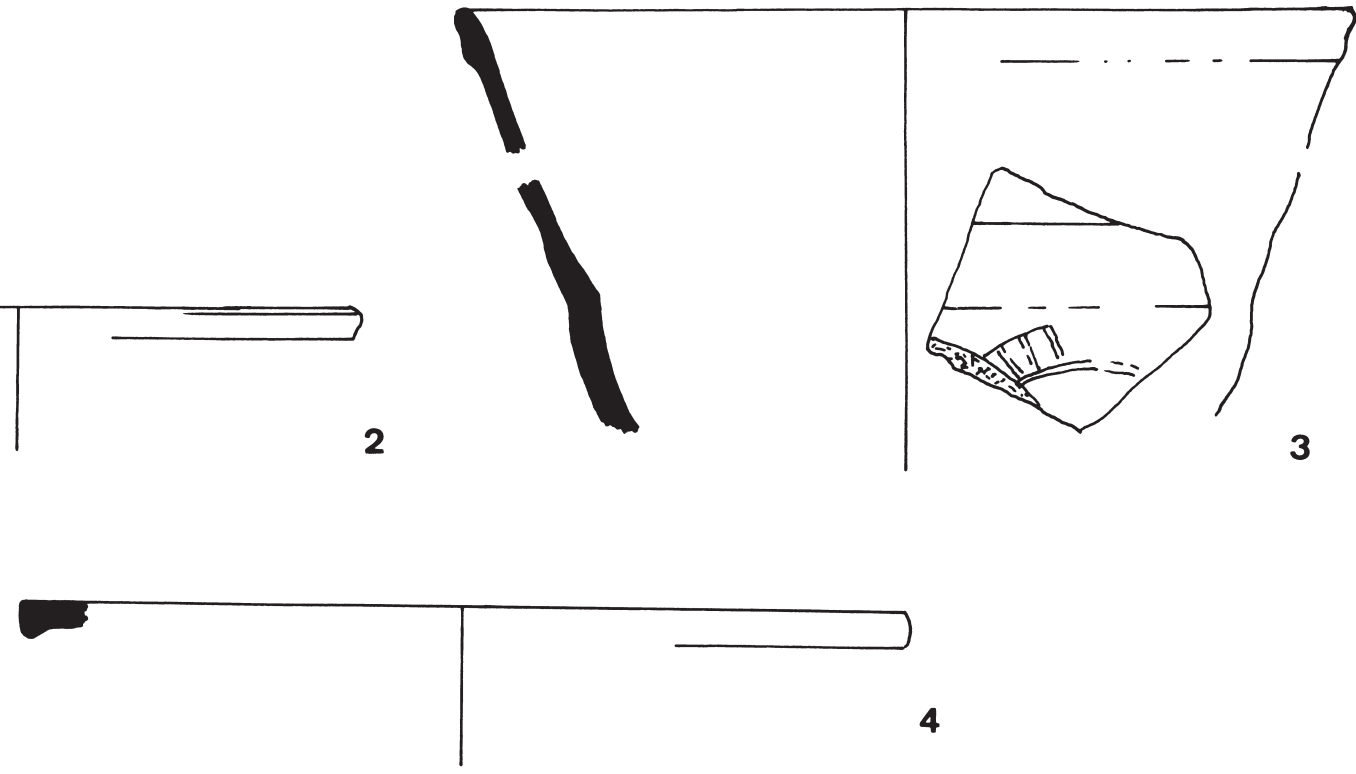

4
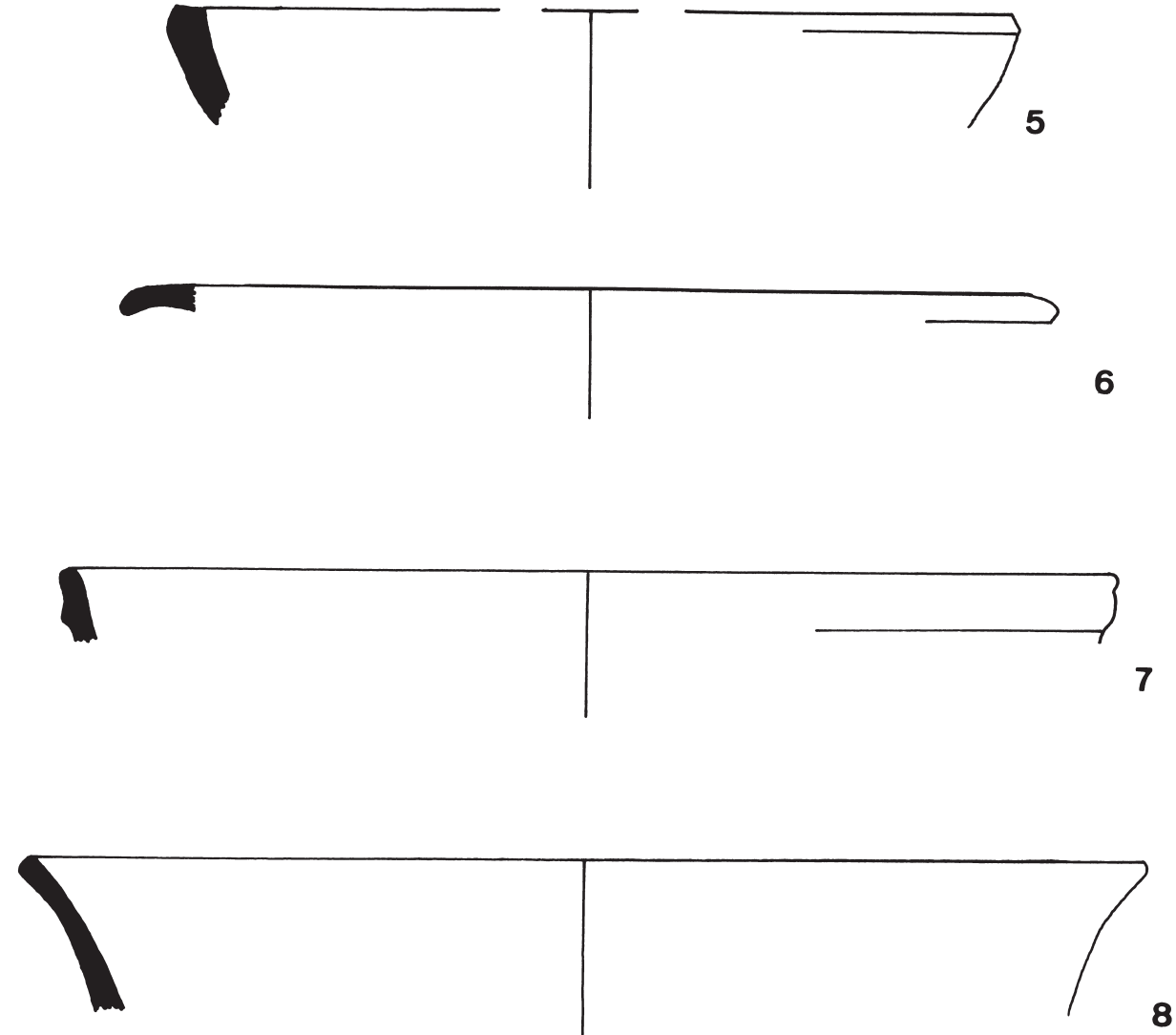

FIG. 17.

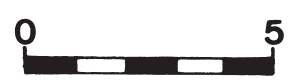

U.E 4165: 1. T.S.H., 2-8. T.S.H.T. 

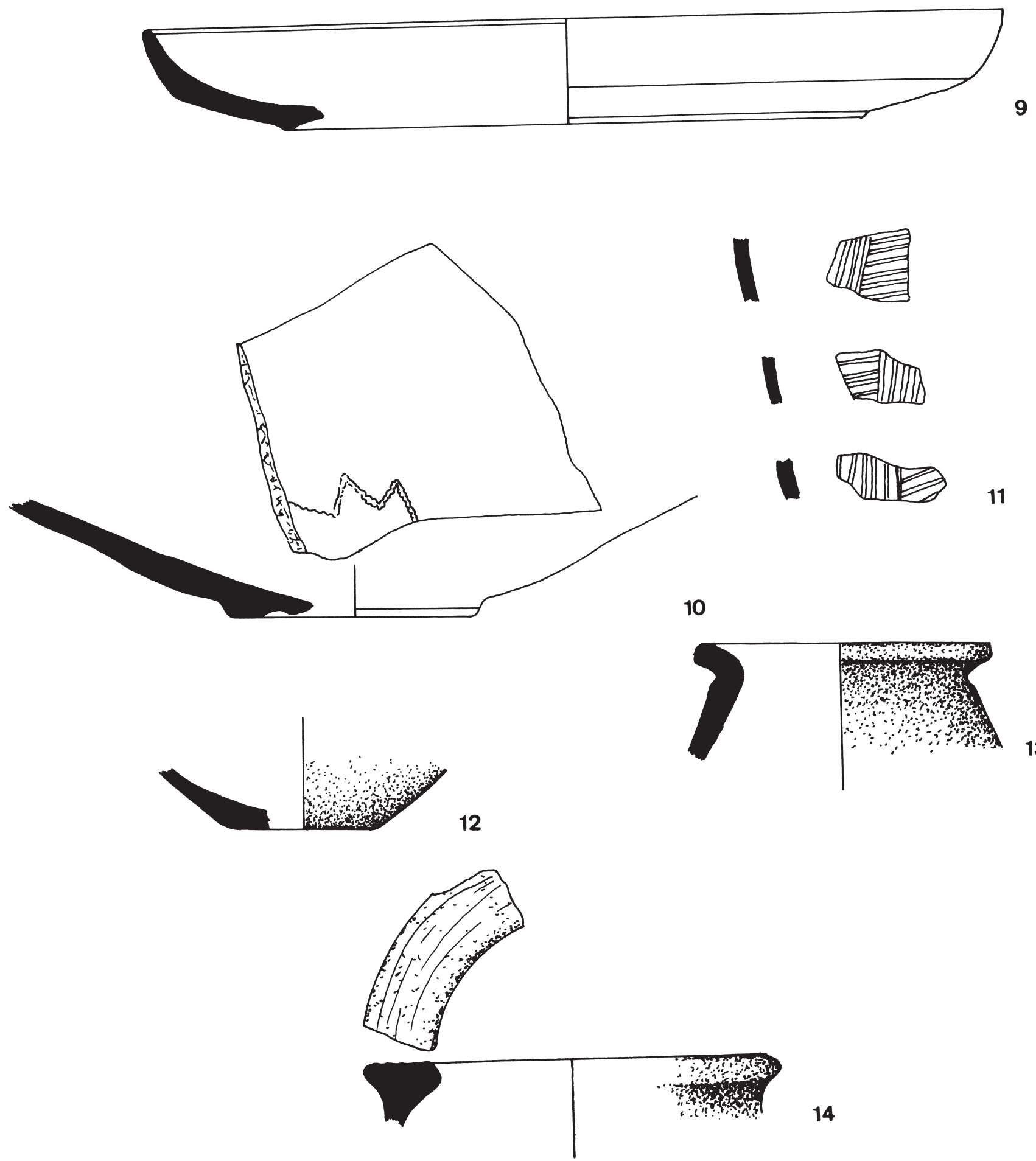

14
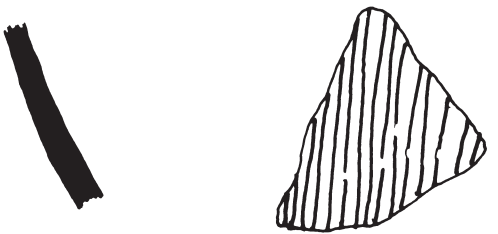

15

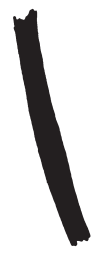

FIG. 18.

U.E 4165: 9-11. T.S.H.T., 12. C.C.R. (G.1), 13-16. C.C.R (G.2). 

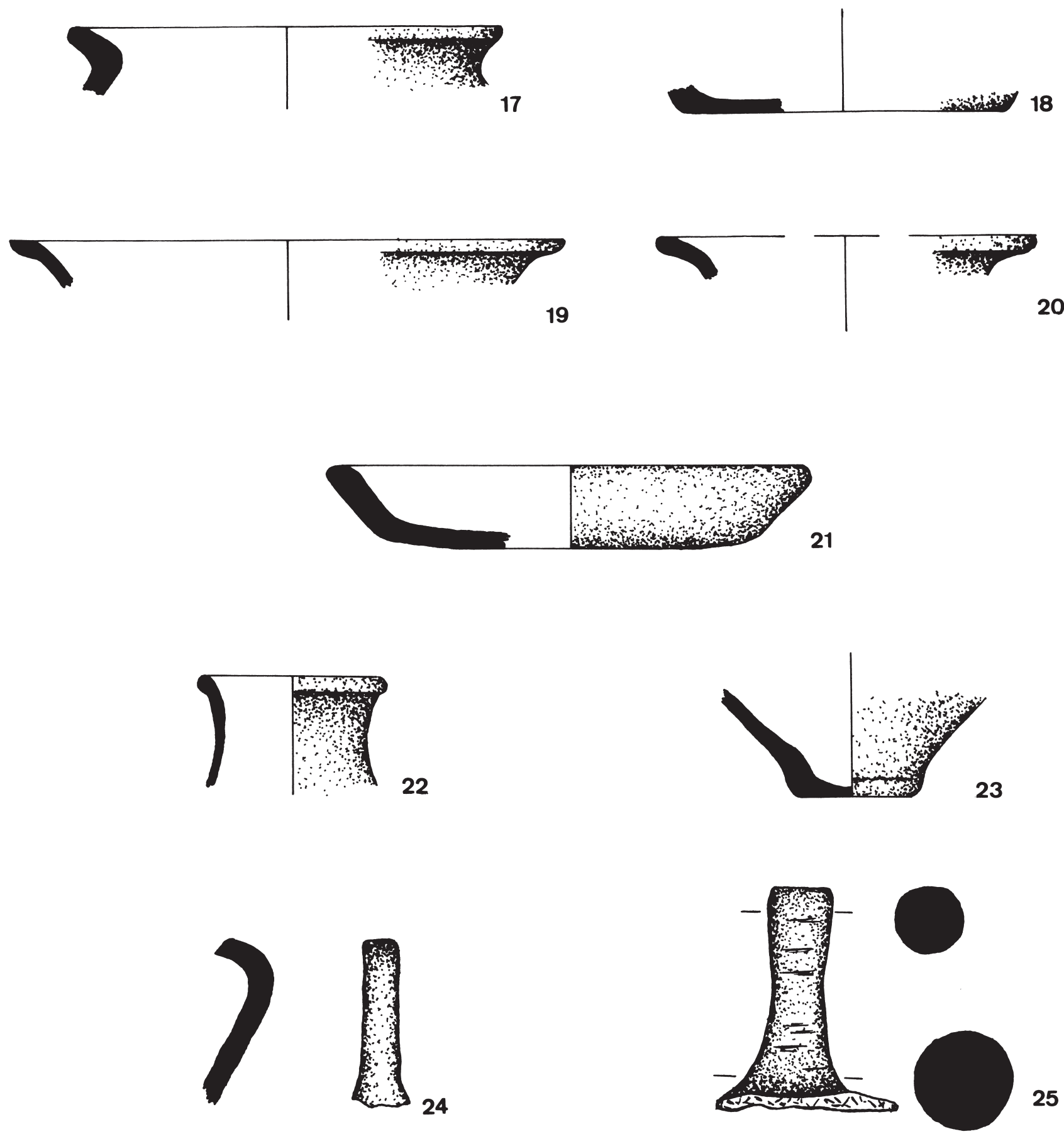

25
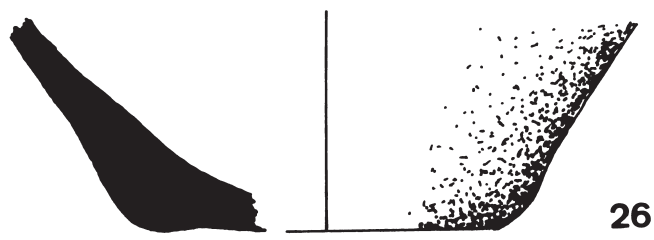

26

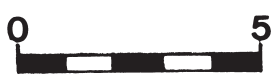

FIG. 19.

U.E 4165: 17-18. C.C.R (G.2), 19-20. C.C.R. (G.3), 21. C.C.R. (G.4), 22-25. C.C.R. (G.5), 26. C.C.R. (G.6). 

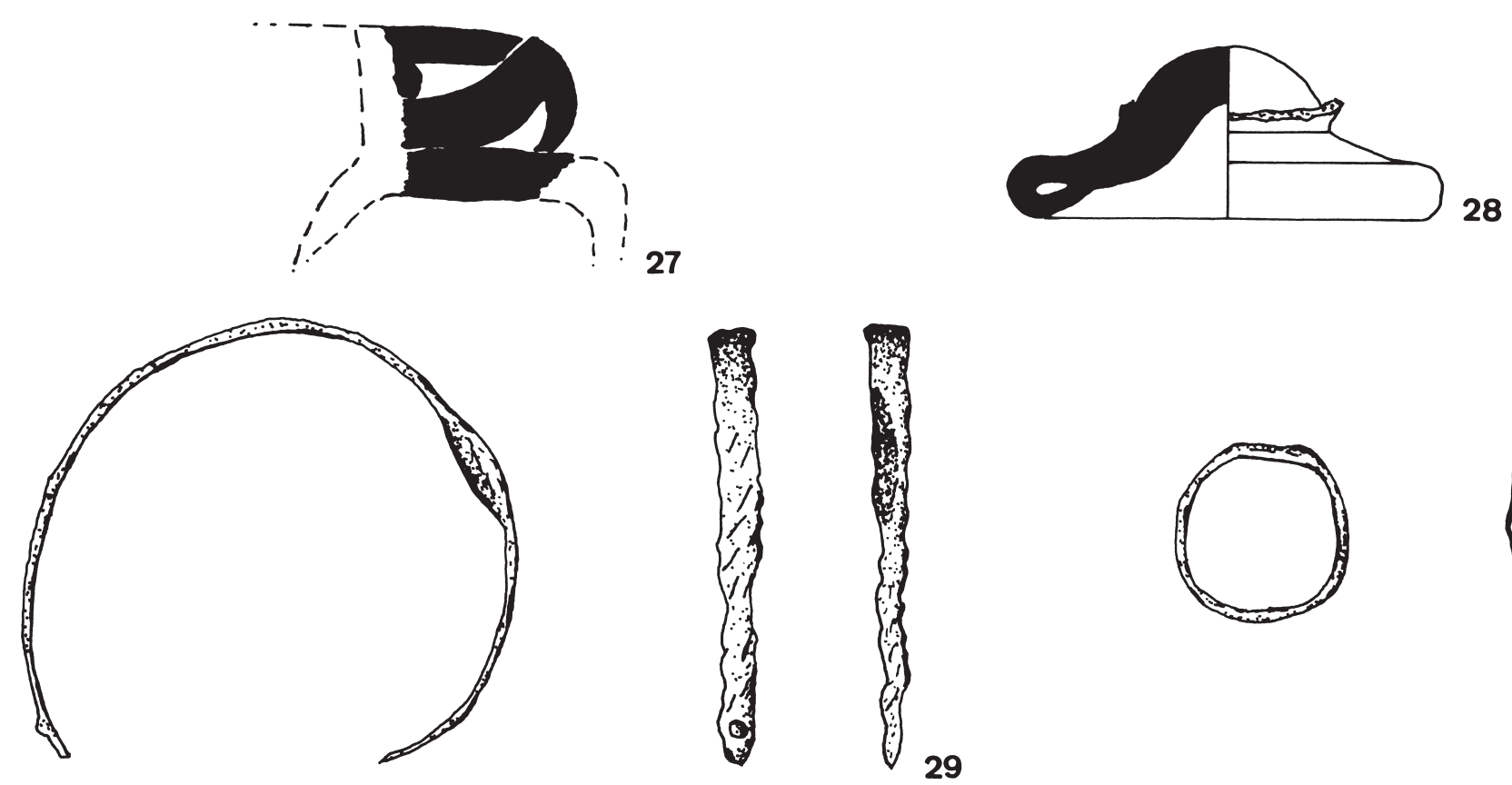

30
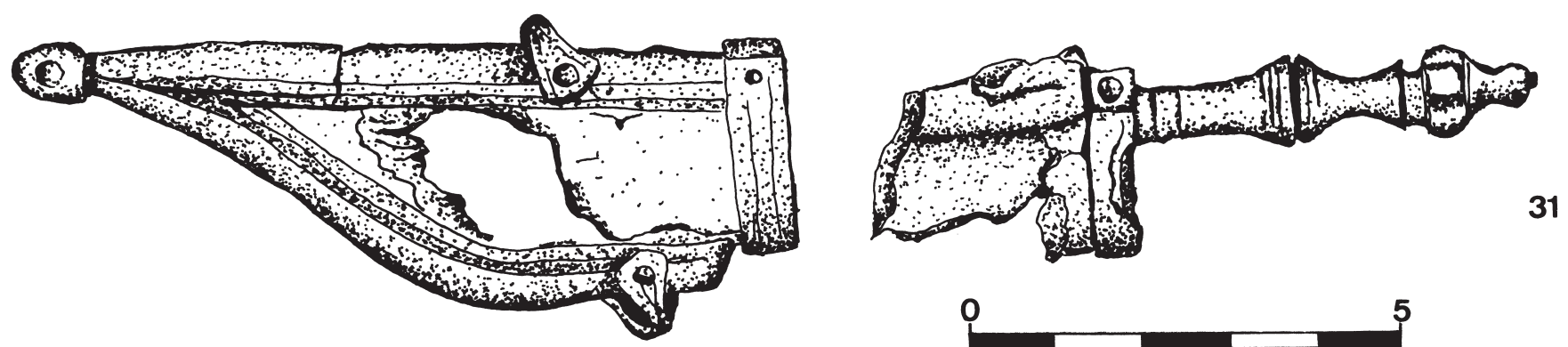

888

32
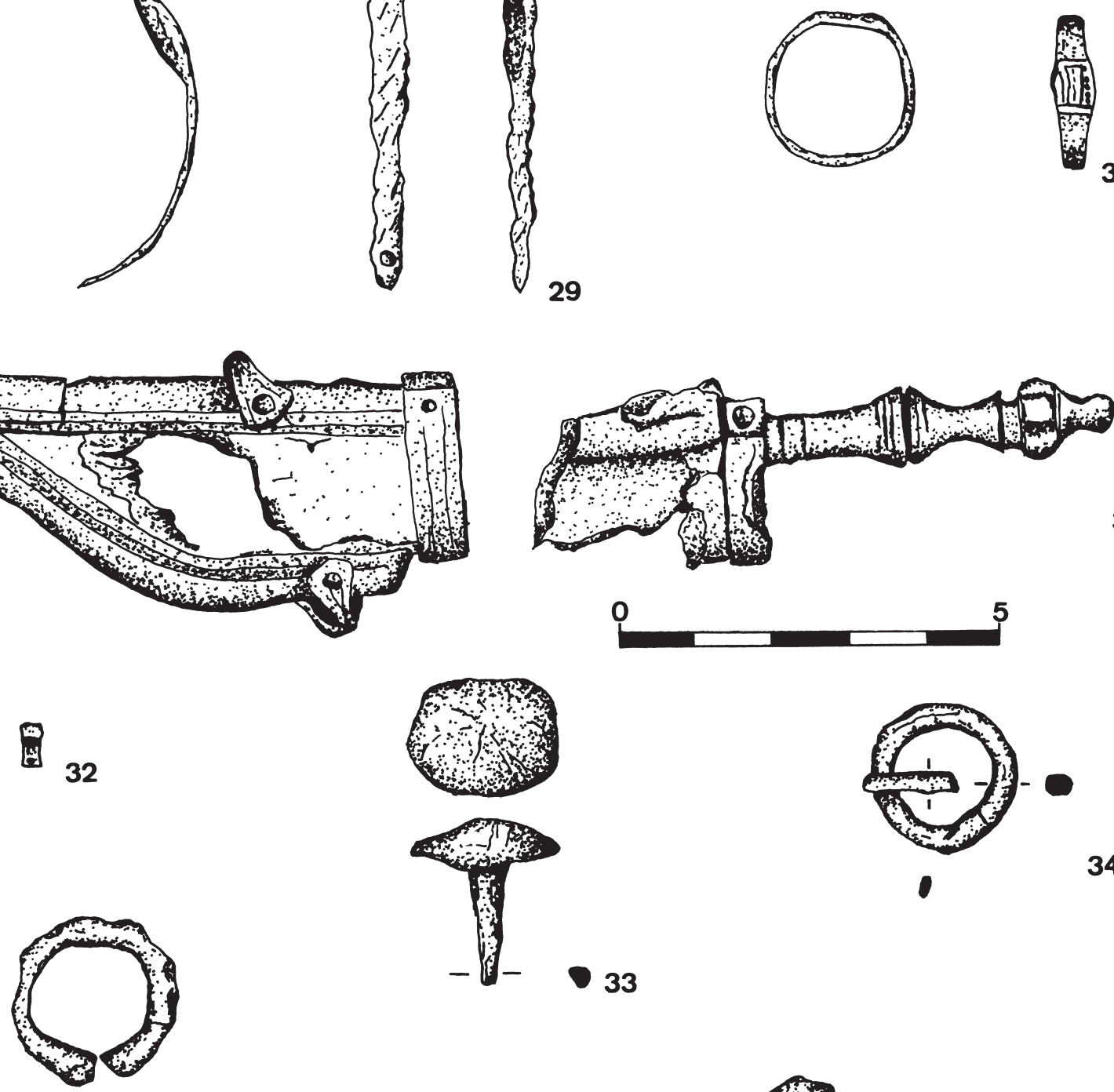

31
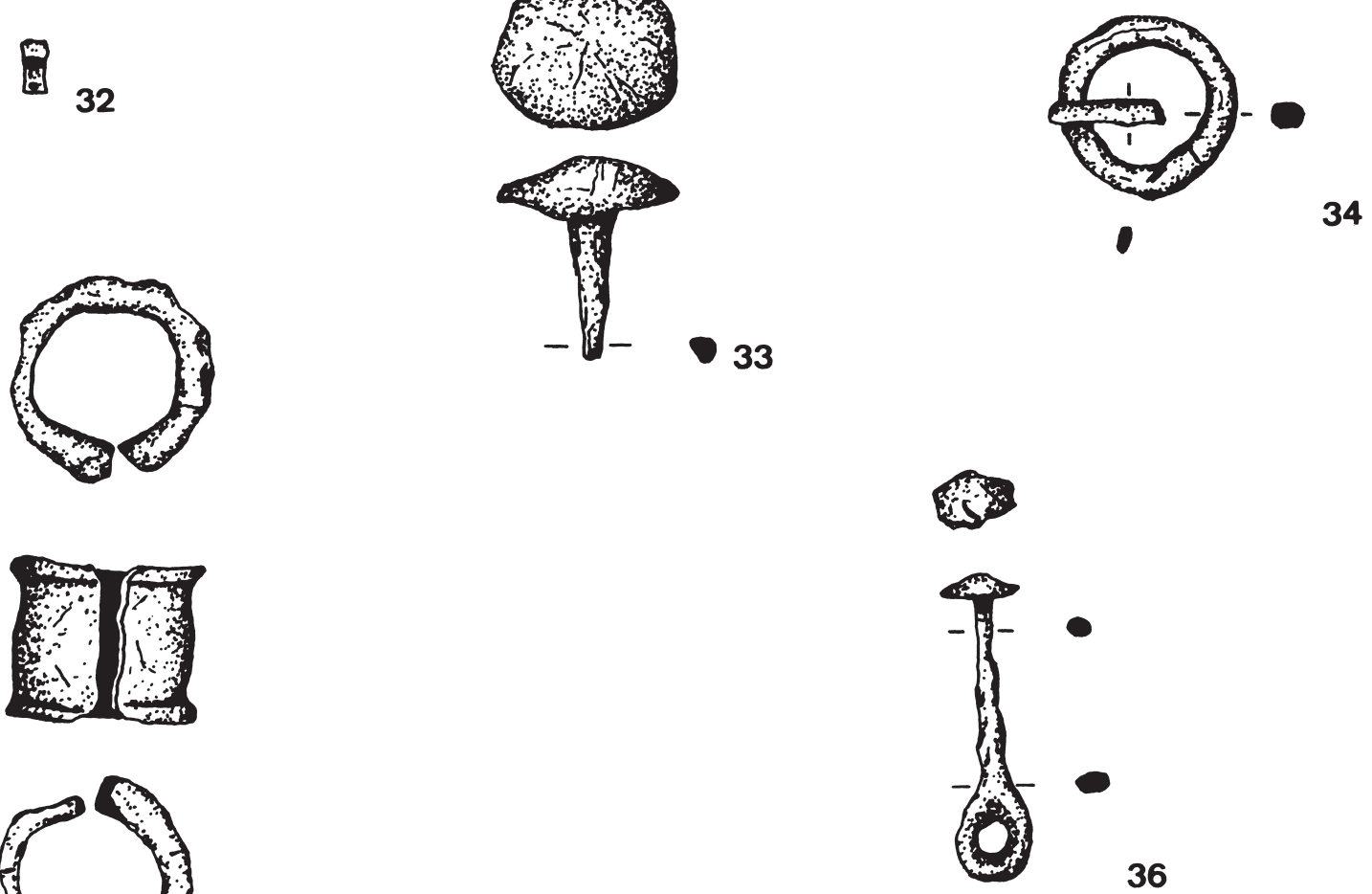

FIG. 20.

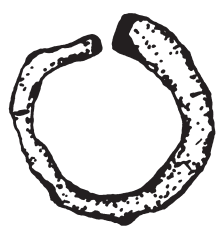

35

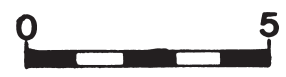

U.E 4165: 27-28. VIDRIO, 29. PULSERA (Br), 30. ANILLO (Br), 31. PUÑAL TIPO SIMANCAS, 32. AMELLA (Br), 33. TACHÓN (Fe), 34. HEBILLA (Fe), 35. ABRAZADERA (Fe), 36. HEMBRILLA $(\mathrm{Fe})$. 

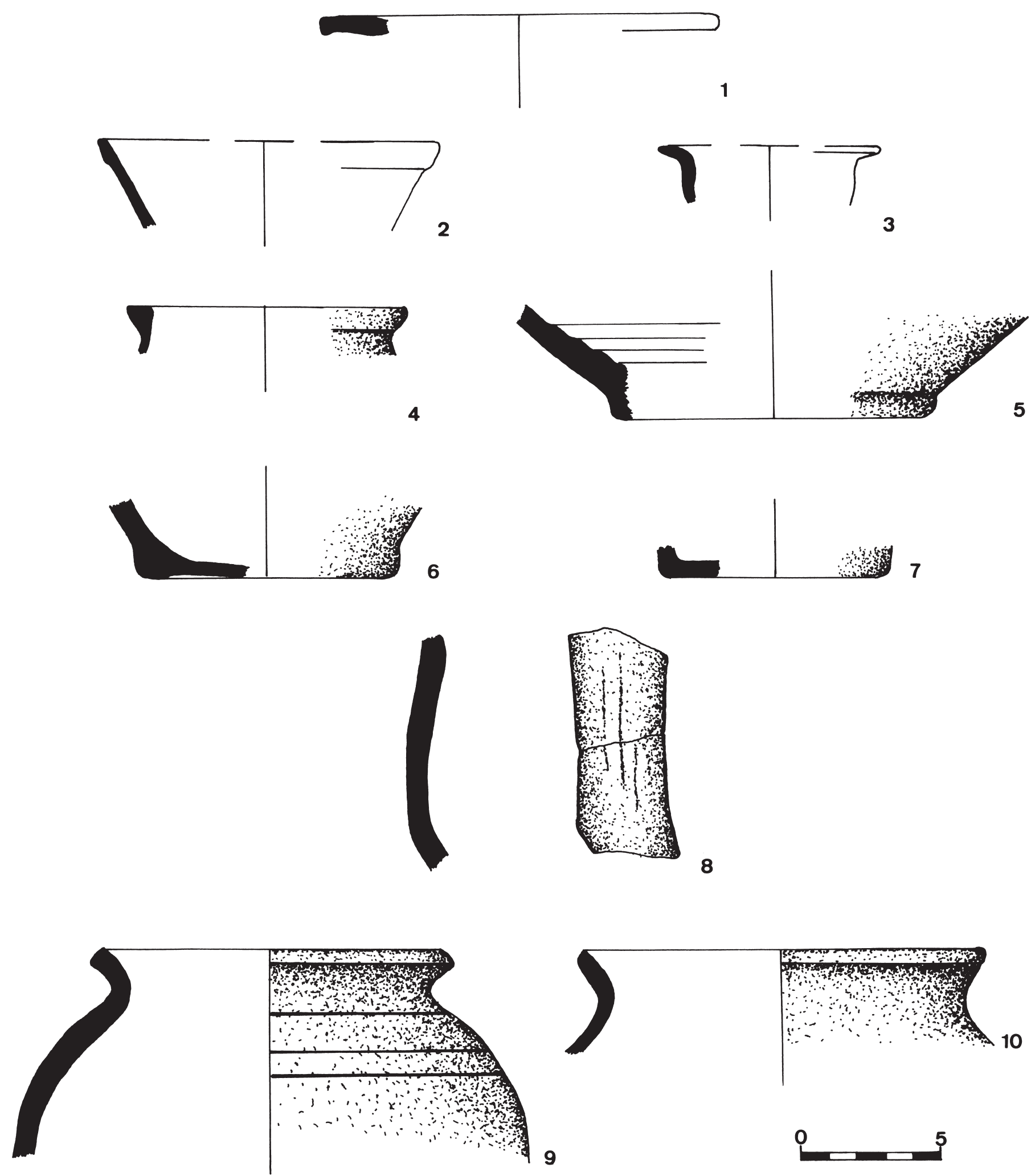

FIG. 21.

U.E 4166: 1-2. T.S.H.T., 3. PAREDES FINAS, 4-8. C.C.R. (G.1), 9-10. C.C.R (G.2). 

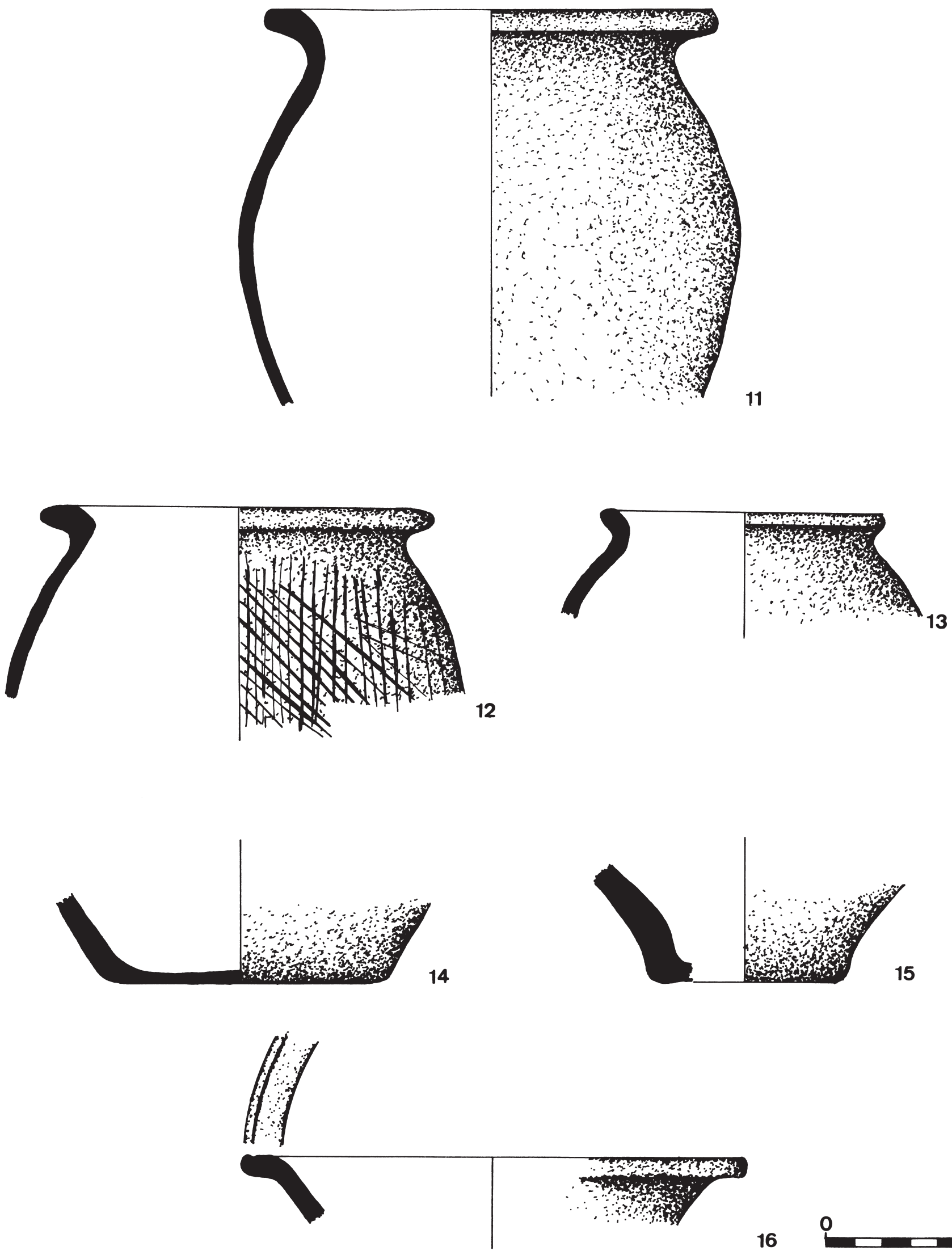

16

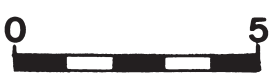

FIG. 22.

U.E 4166: 11-14. C.C.R. (G.2), 15. C.C.R (G.3), 16. C.C.R. (G.4). 

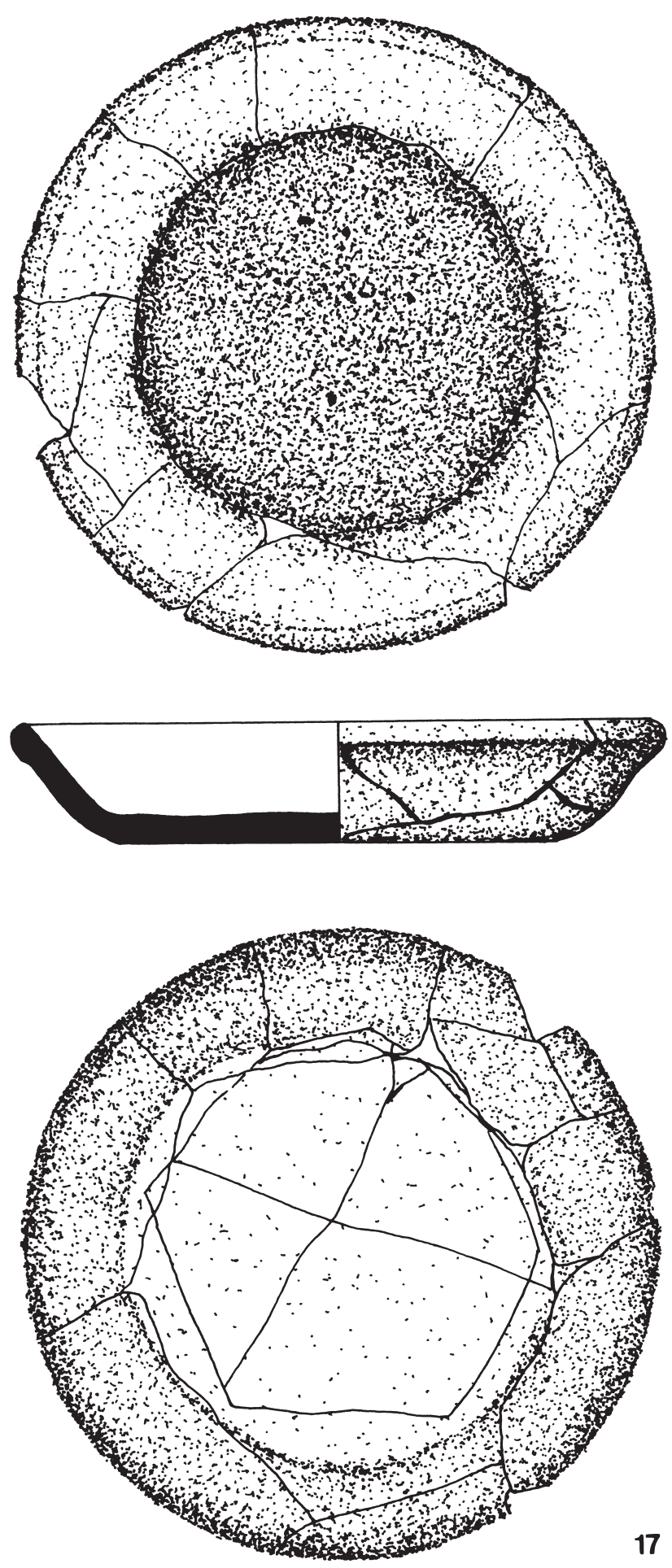

0

FIG. 23.

U.E 4166: 17. C.C.R. (G.4). 

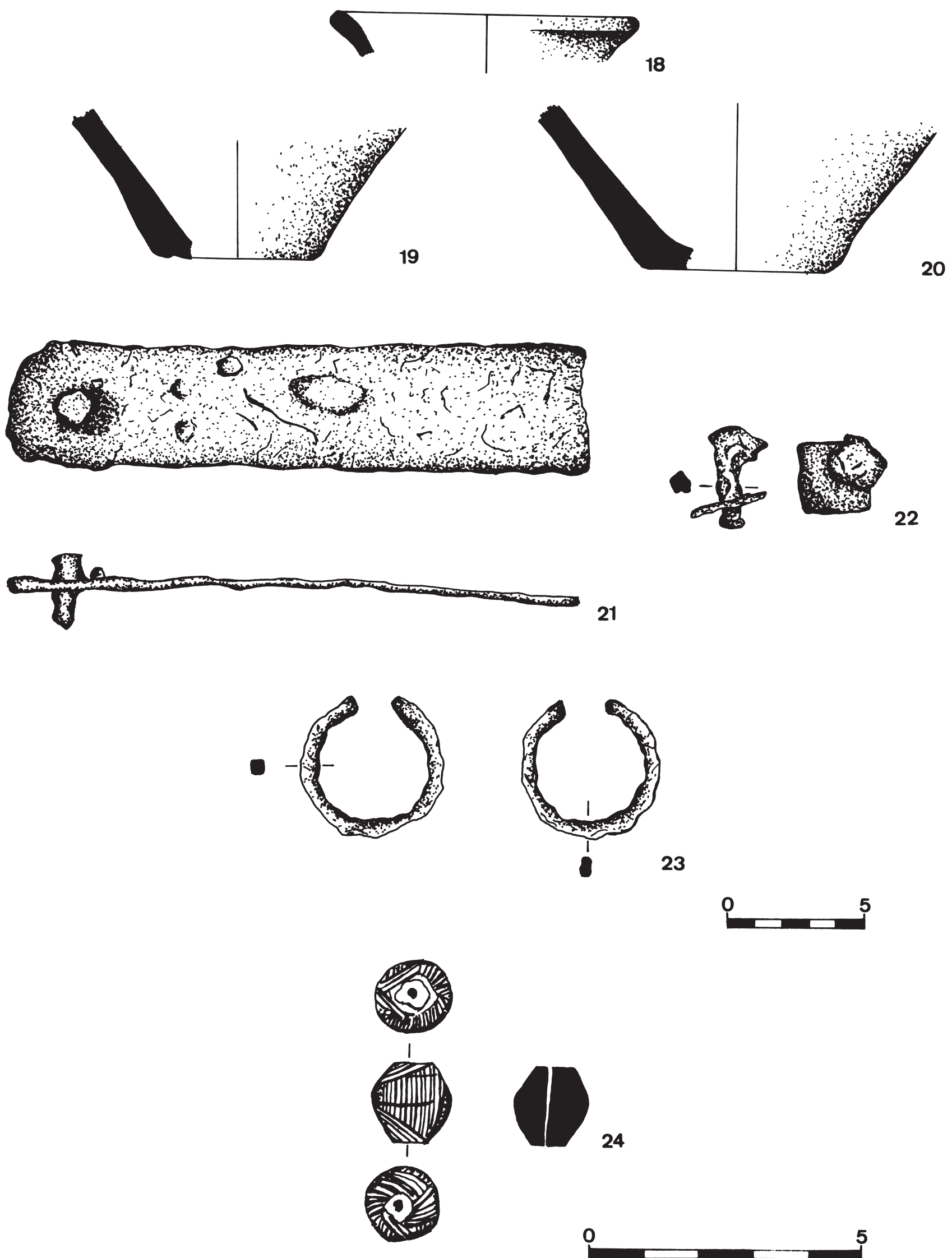

FIG. 24.

U.E 4166: 18. C.C.R. (G.5), 19-20. C.C.R. (G.6), 21. PLACA (Fe), 22. POMO (Fe), 23. ANILLA (Fe), 24. CUENTA DE AZABACHE. 

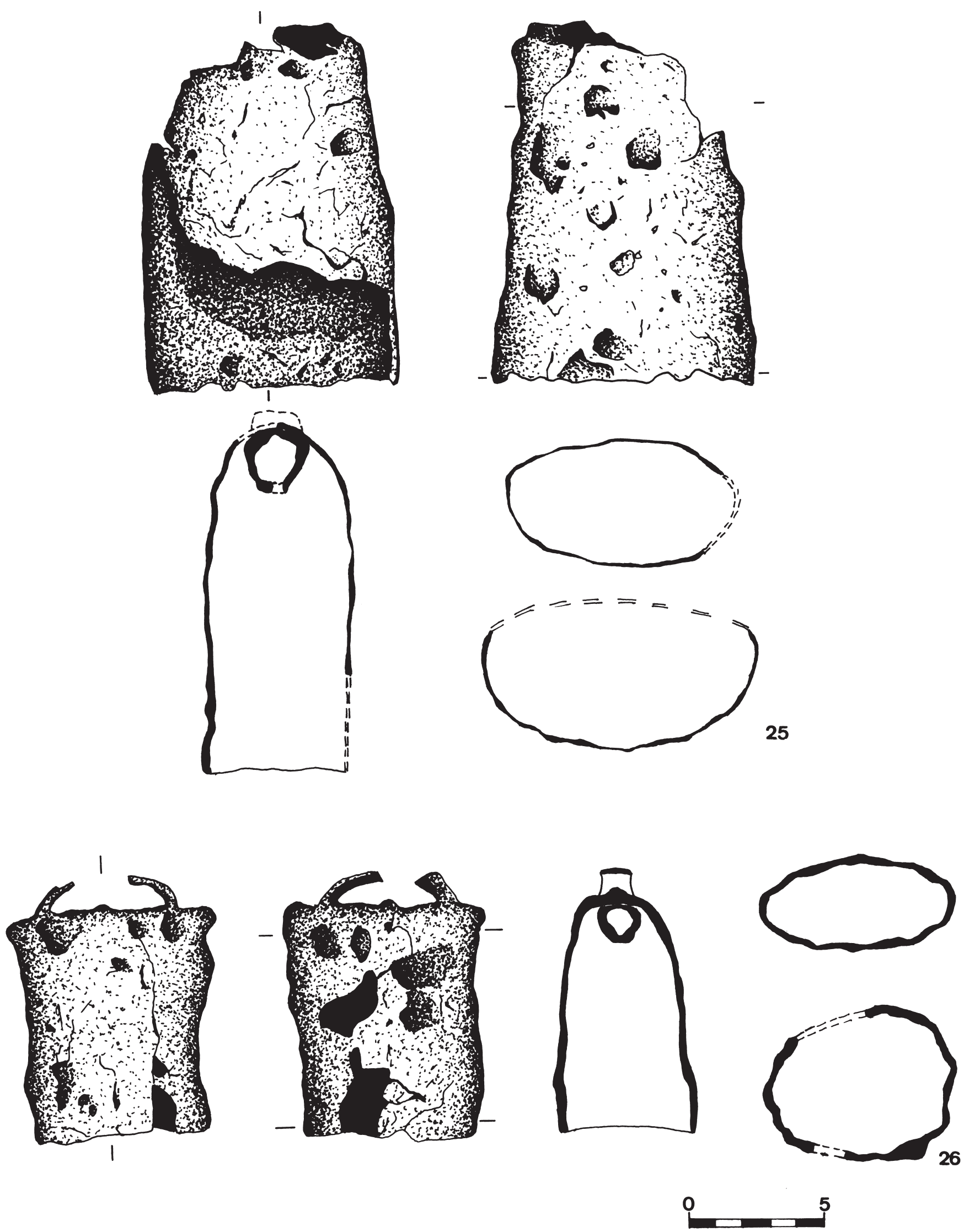

FIG. 25.

U.E 4166: 25-26. CENCERROS DE LATÓN. 


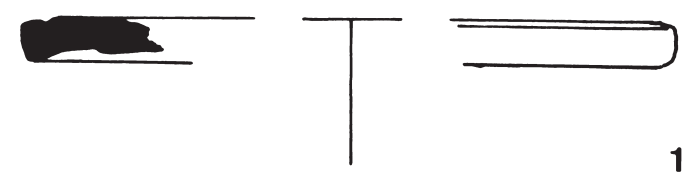

1
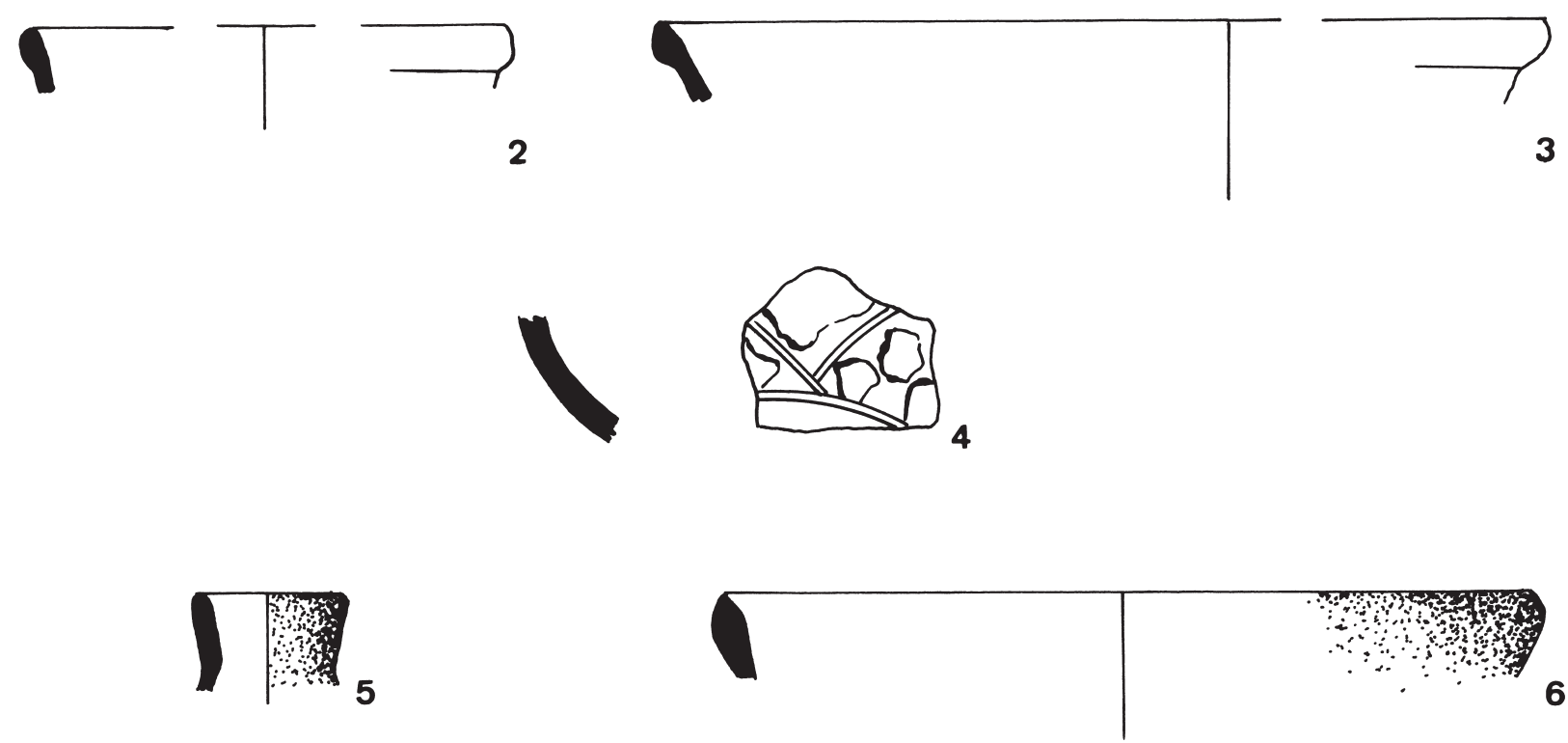

6
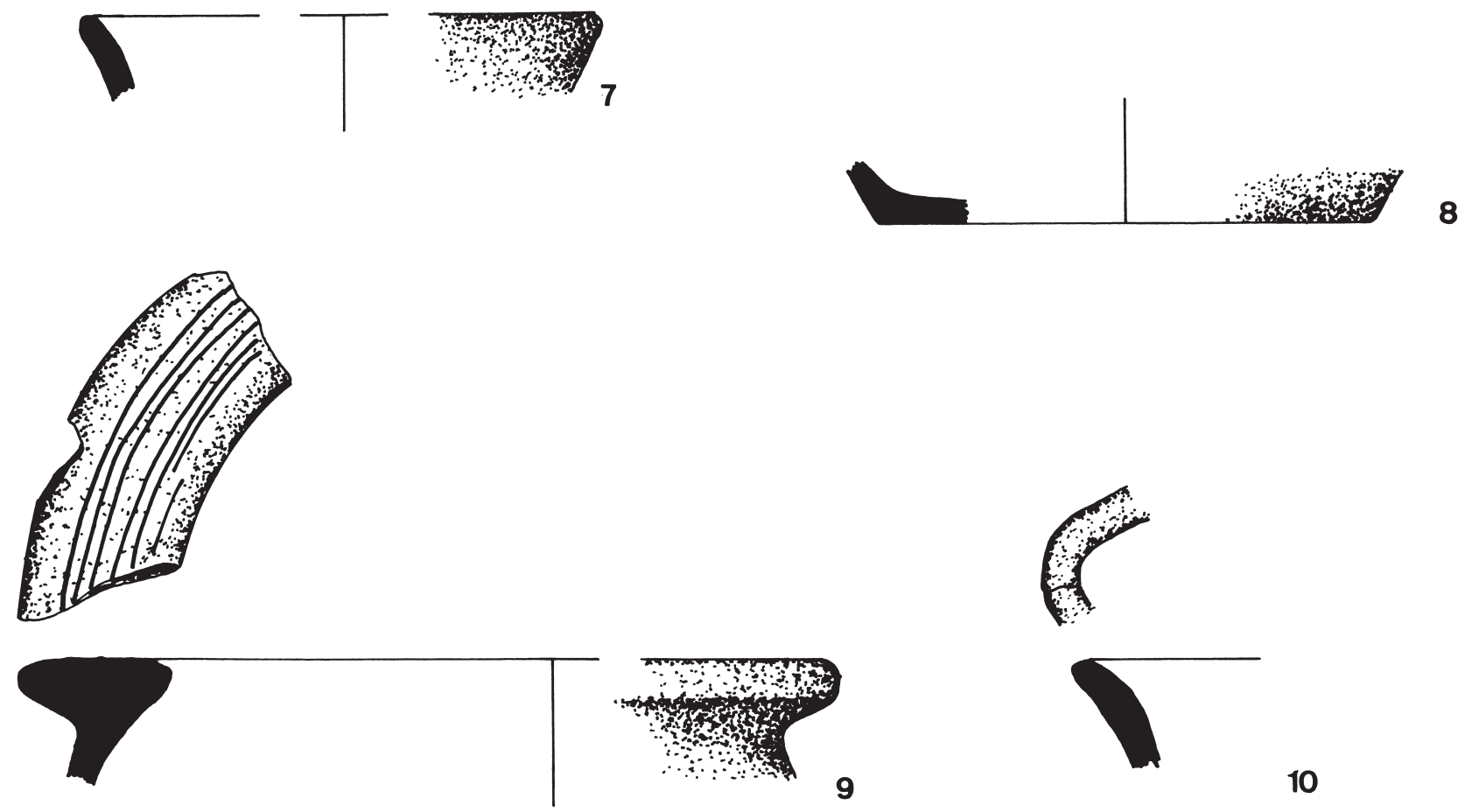

9

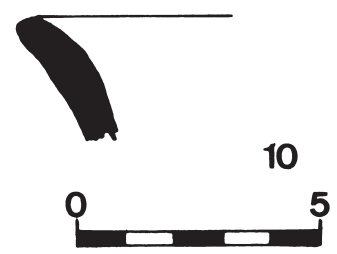

FIG. 26.

U.E 4169: 1. T.S.H., 2-4. T.S.H.T., 5-6. C.C.R. (G.1), 7-10. C.C.R (G.2). 

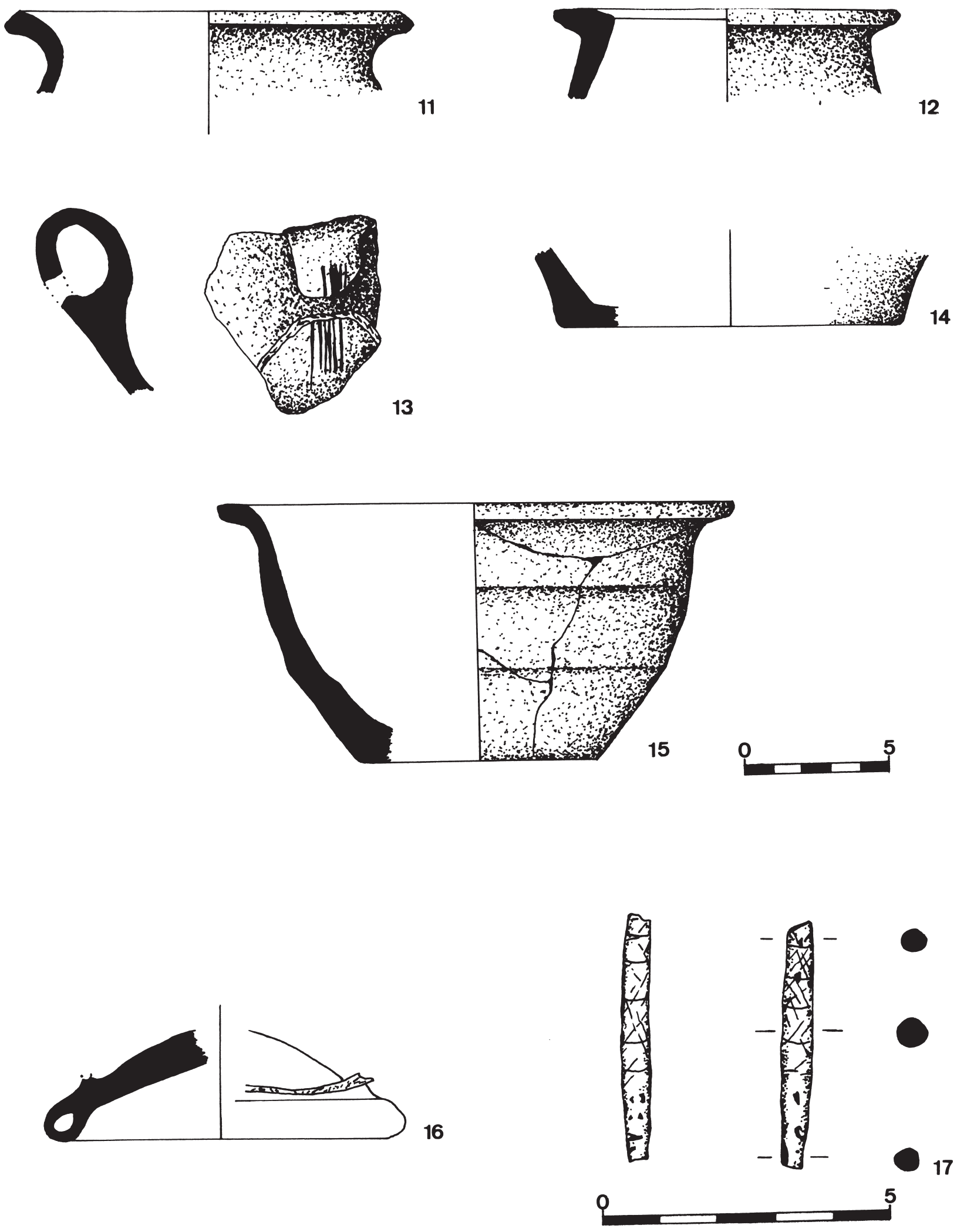

FIG. 27.

U.E 4169: 11-14. C.C.R. (G.3), 15. C.C.R (G.6), 16. VIDRIO, 17. ACUS CRINALIS. 

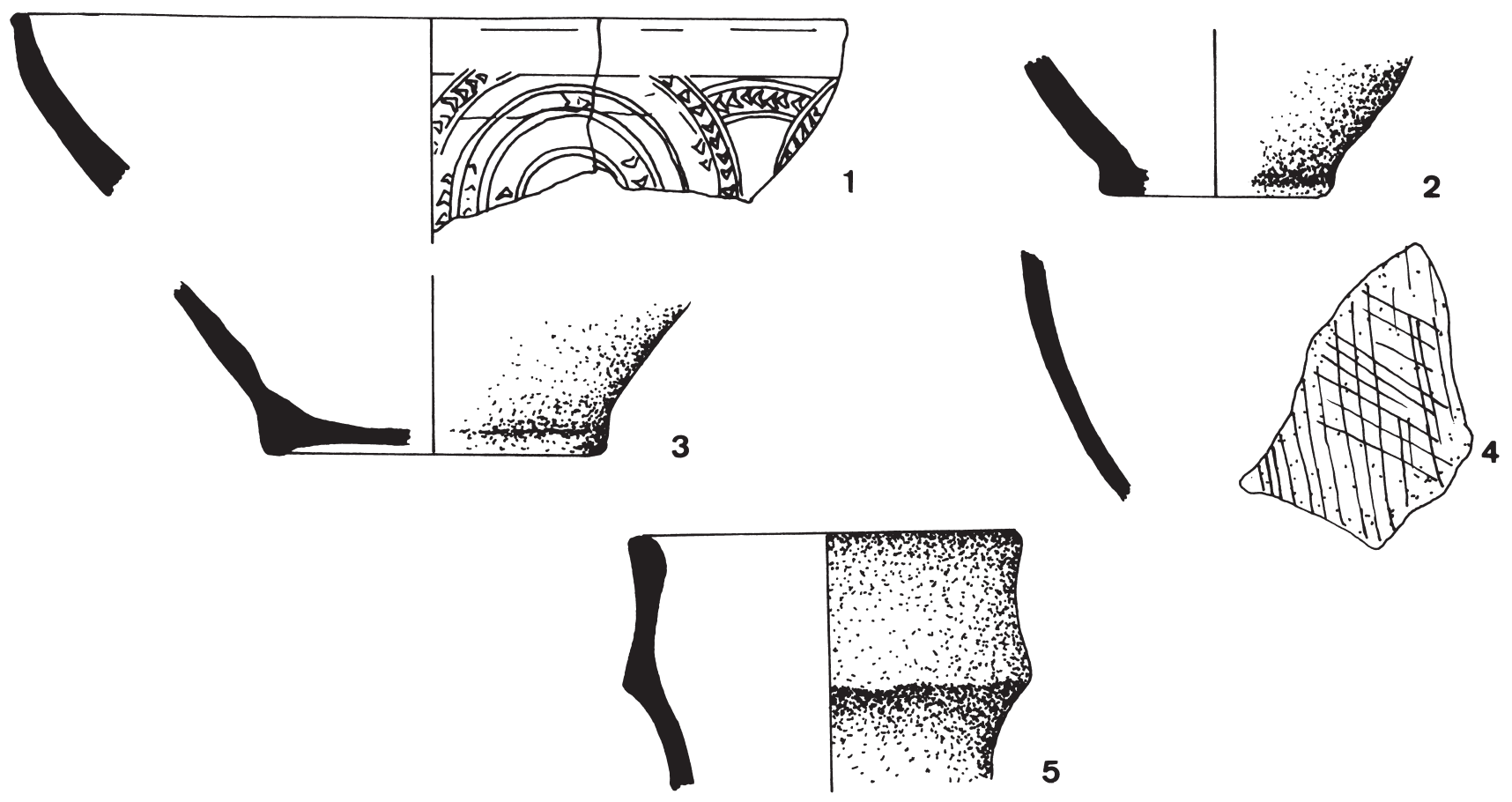

5

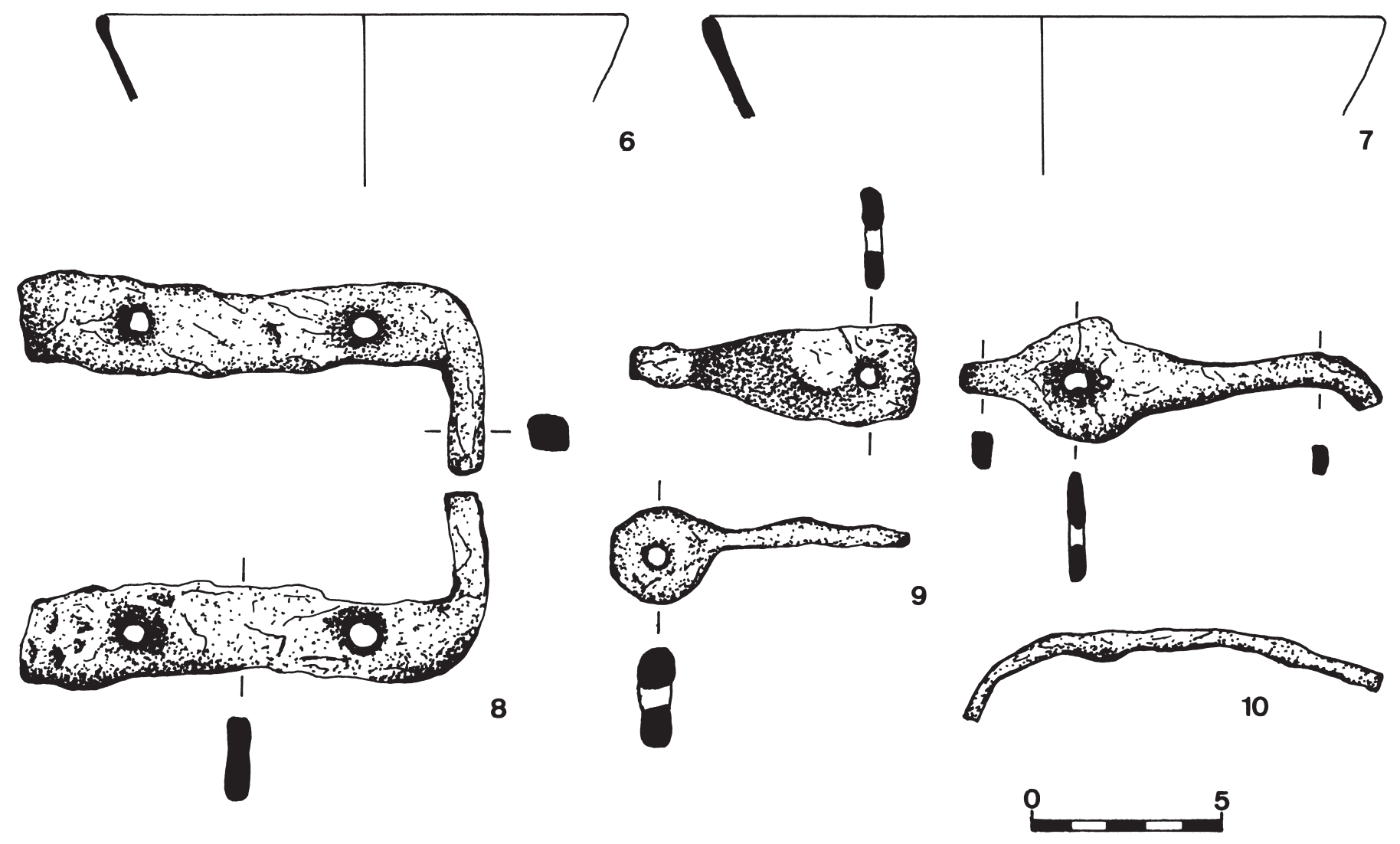

FIG. 28.

U.E 4170: 1. T.S.H.T., 2-3. C.C.R. (G.2), 4-5. C.C.R (G.3), 6-7. VIDRIO, 8. BISAGRA (Fe), 9. BISAGRA (Fe), 10. COLGADOR (Fe). 

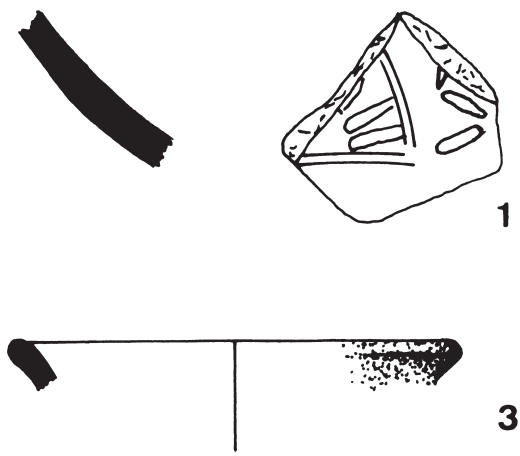

3
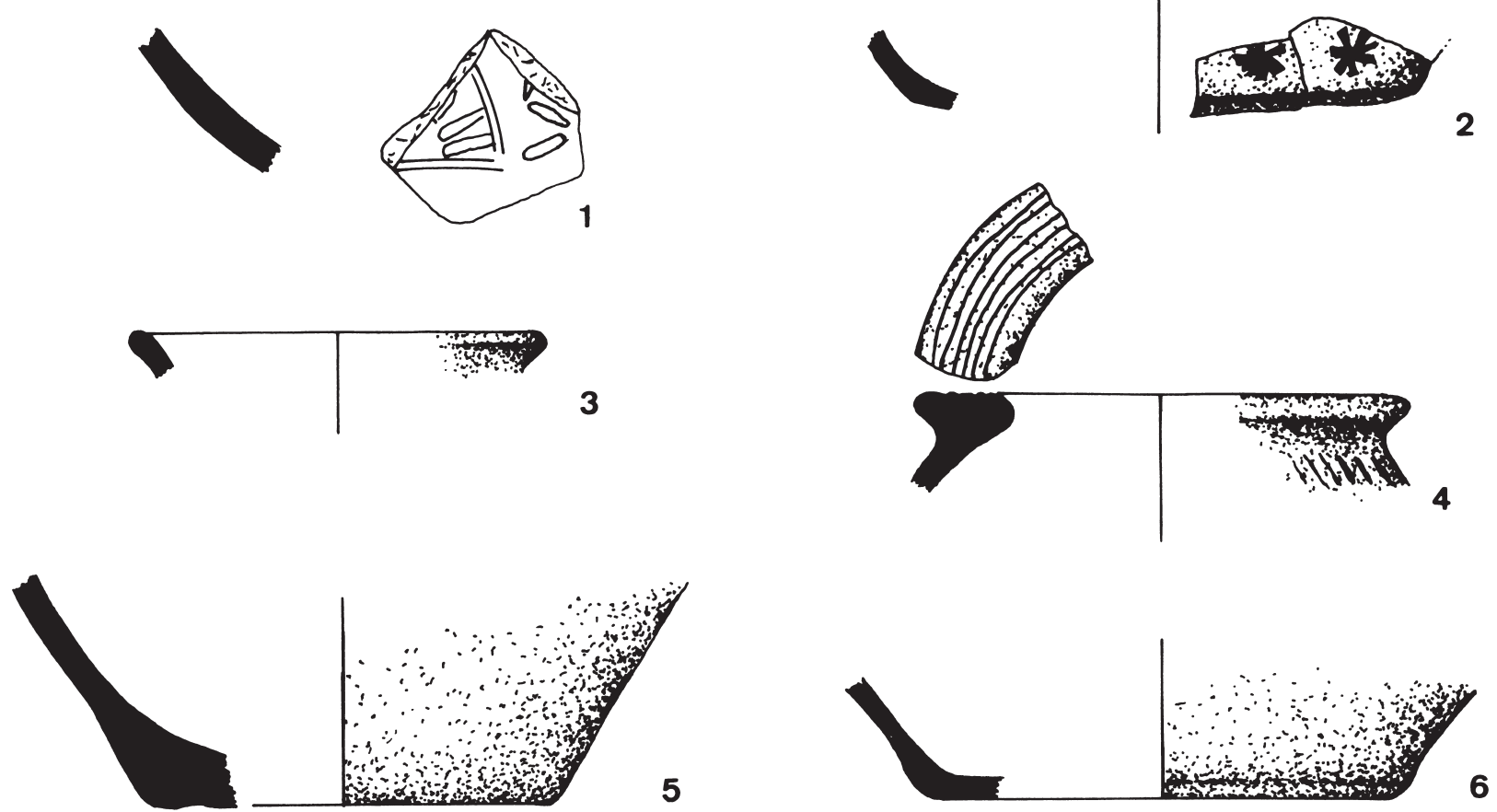
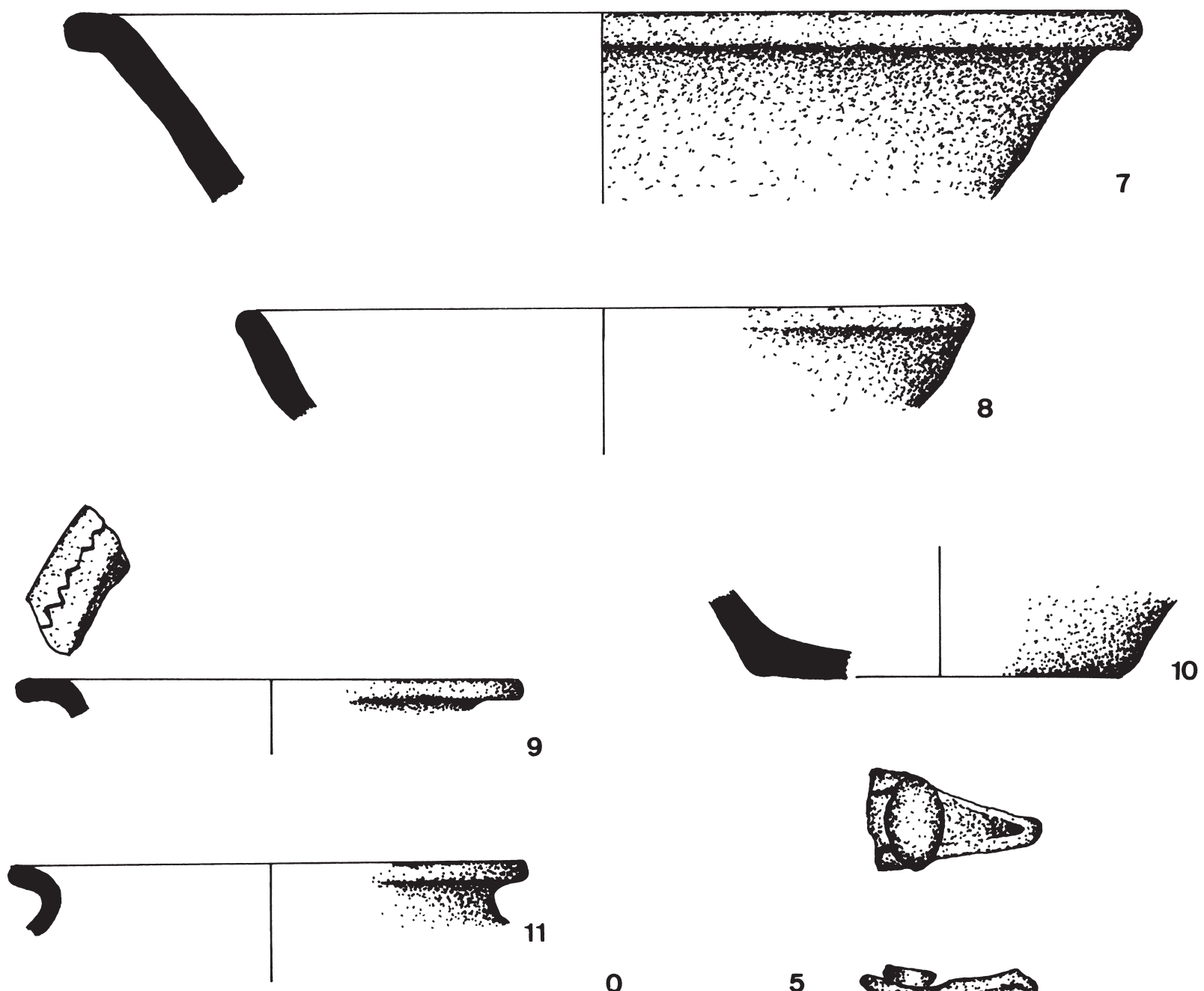

FIG. 29.

9

U.E 4401: 1. T.S.H.T., 2. IMITACIÓN T.S.G.G.T., 3. C.C.R (G.1), 4-5. C.C.R. (G.3), 6. C.C.R. (G.2), 78. C.C.R. (G.4), 9-10. C.C.R. (G.6), 11. C.C.R. (G.10), 12. PLACA (Fe). 